\title{
Convalescent Plasma for the Prevention and Treatment of COVID-19: A Systematic Review and Quantitative Analysis
}

\author{
Henry T Peng ${ }^{1}$, PhD; Shawn G Rhind ${ }^{1}$, PhD; Andrew Beckett ${ }^{2,3}$, MD \\ ${ }^{1}$ Defence Research and Development Canada, Toronto Research Centre, Toronto, ON, Canada \\ ${ }^{2}$ St. Michael's Hospital, Toronto, ON, Canada \\ ${ }^{3}$ Royal Canadian Medical Services, Ottawa, ON, Canada
}

Corresponding Author:

Henry T Peng, PhD

Defence Research and Development Canada

Toronto Research Centre

1133 Sheppard Avenue West

Toronto, ON, M3K 2C9

Canada

Phone: 14166352129

Email: henry.peng@drdc-rddc.gc.ca

\section{Related Article:}

This is a corrected version. See correction statement in: https://publichealth.jmir.org/2021/6/e31554/

\section{Abstract}

Background: The COVID-19 pandemic, caused by a novel coronavirus termed SARS-CoV-2, has spread quickly worldwide. Convalescent plasma (CP) obtained from patients following recovery from COVID-19 infection and development of antibodies against the virus is an attractive option for either prophylactic or therapeutic treatment, since antibodies may have direct or indirect antiviral activities and immunotherapy has proven effective in principle and in many clinical reports.

Objective: We seek to characterize the latest advances and evidence in the use of CP for COVID-19 through a systematic review and quantitative analysis, identify knowledge gaps in this setting, and offer recommendations and directives for future research.

Methods: PubMed, Web of Science, and Embase were continuously searched for studies assessing the use of CP for COVID-19, including clinical studies, commentaries, reviews, guidelines or protocols, and in vitro testing of CP antibodies. The screening process and data extraction were performed according to PRISMA (Preferred Reporting Items for Systematic Reviews and Meta-Analyses) guidelines. Quality appraisal of all clinical studies was conducted using a universal tool independent of study designs. A meta-analysis of case-control and randomized controlled trials (RCTs) was conducted using a random-effects model.

Results: Substantial literature has been published covering various aspects of CP therapy for COVID-19. Of the references included in this review, a total of 243 eligible studies including 64 clinical studies, 79 commentary articles, 46 reviews, 19 guidance and protocols, and 35 in vitro testing of CP antibodies matched the criteria. Positive results have been mostly observed so far when using CP for the treatment of COVID-19. There were remarkable heterogeneities in the CP therapy with respect to patient demographics, donor antibody titers, and time and dose of CP administration. The studies assessing the safety of CP treatment reported low incidence of adverse events. Most clinical studies, in particular case reports and case series, had poor quality. Only 1 RCT was of high quality. Randomized and nonrandomized data were found in 2 and 11 studies, respectively, and were included for meta-analysis, suggesting that CP could reduce mortality and increase viral clearance. Despite promising pilot studies, the benefits of CP treatment can only be clearly established through carefully designed RCTs.

Conclusions: There is developing support for CP therapy, particularly for patients who are critically ill or mechanically ventilated and resistant to antivirals and supportive care. These studies provide important lessons that should inform the planning of well-designed RCTs to generate more robust knowledge for the efficacy of CP in patients with COVID-19. Future research is necessary to fill the knowledge gap regarding prevention and treatment for patients with COVID-19 with CP while other therapeutics are being developed.

(JMIR Public Health Surveill 2021;7(4):e25500) doi: 10.2196/25500 


\section{KEYWORDS}

COVID-19; SARS-CoV-2; antibodies; convalescent plasma; immunotherapy; prevention; treatment; review; quantitative; therapeutic; immunology; research; literature; knowledge; recommendation

\section{Introduction}

SARS-CoV-2, the cause of COVID-19, was declared a pandemic in early 2020 by the World Health Organization [1,2]. This is the third coronavirus to emerge in the past two decades, causing multinational outbreaks and carrying substantial morbidity and mortality [3]. COVID-19 is characterized by a spectrum of symptoms, ranging from mild subclinical infection with self-limiting respiratory tract illness (dry cough, fever, fatigue, difficulty breathing) to severe progressive manifestations (acute respiratory distress, hypercoagulation, hyperinflammation, multi-organ dysfunction, death) in high-risk patients with known comorbidities (advanced age, diabetes, obesity, cardiopulmonary disease) $[4,5]$. Case-fatality rates range from $4 \%$ to $50 \%$, with higher mortality observed in the most critically ill [6]. Growing evidence also suggests that some patients with COVID-19, including those with milder symptoms, will have a prolonged course of recovery including fatigue, cognitive impairment, and cardiopulmonary dysfunction [7]. As such, COVID-19 represents an overwhelming universal health crisis [8], and the burden of this disease continues to threaten lives and livelihoods worldwide [9]. As SARS-CoV-2 and its emerging new mutant strains (which may be associated with an increased efficiency of viral replication, transmission, and virulence in humans) continue to spread globally, international research efforts are being accelerated to identify effective preventive and therapeutic approaches to mitigate its impact [10-12].

The magnitude and urgency of this public health emergency has prompted global scientific collaborations to seek rapid solutions via repurposing of previously approved broad-spectrum antivirals (remdesivir, ritonavir, hydroxychloroquine, interferon) $[13,14]$ and therapeutic doses of corticosteroids (dexamethasone, hydrocortisone, methylprednisolone) $[15,16]$ for high-risk patients while fast-tracking development of vaccines and other novel therapeutics [17]. To that end, great advances in understanding the biology of this new coronavirus and the natural history of the disease have been achieved [18,19]. Moreover, the unprecedented development of multiple COVID-19 vaccines capable of eliciting immunological protection, in less than a year from identification of the causative agent, has been a remarkable success and remains the best hope for ending this pandemic [20].

Despite this incredible progress on COVID-19, many challenges remain post vaccine development including ongoing vaccine deployment, large-scale production and distribution of billions of vaccine doses [21], and uncertainty over the effectiveness of current vaccines against more transmissible new variants [22]. These factors, combined with public hesitation around vaccination, have casted doubt on the likelihood of achieving worldwide herd immunity in the near future [23]. Consequently, other therapeutic strategies to impair virus infection or to counteract further disease spread are still needed, at least until more effective drugs are available or vaccines are distributed and administered to everyone [24].

In the absence of definitive treatment against this new human pathogen, clinical management of hospitalized, severely ill patients remains mainly supportive care, including oxygen and mechanical ventilation, and is based largely on preclinical studies or previous experience with severe acute respiratory syndrome-related coronavirus (SARS-CoV) [25]. Thus, an effective evidence-based therapeutic intervention is urgently needed to reduce the morbidity, mortality, and length of in-hospital stay for patients with COVID-19.

Passive immunotherapy with convalescent plasma (CP), hyperimmune $\gamma$-globulin, or artificially produced monoclonal antibodies are beneficial for treatment or prophylaxis of several infections, and these approaches are under investigation as potential therapeutic modalities for the management and prevention of COVID-19 [26]. Passive immunotherapy with human convalescent blood products, in particular $\mathrm{CP}$, is a promising strategy for the prevention and treatment of COVID-19 [27-29]. Although further research is needed to determine the utility of immunotherapy with $\mathrm{CP}$ or monoclonal antibodies for the treatment of patients who are symptomatic and potentially for use as postexposure prophylaxis, initial findings in limited clinical trials suggest these interventions are safe and can be effective, particularly when administered early in the course of treatment [29]. Experience suggests that CP therapy could be used as an empirical treatment modality to prevent further progression or promote early recovery in patients who are critically ill with COVID-19 [30,31]. CP has been used safely for decades to treat infectious diseases where no specific treatment is available [32,33]. In the late 19th and early 20th century, $\mathrm{CP}$ was given to treat a wide range of viral infections, including diphtheria, polio, measles, mumps, and Spanish influenza A (H1N1) [34-36]. Although no randomized trials were conducted, a retrospective meta-analysis of studies on the use of CP during the Spanish influenza flu pandemic showed a significant decrease in mortality in patients who received $\mathrm{CP}$ versus those given plasma from unexposed donors [37]. After World War II, plasma became a valuable pharmaceutical component, which used it for diverse products to successfully treat everything from bleeding disorders to immune deficiencies to hypovolemic shock [38]. Since then, CP has been used in outbreaks of Ebola and other coronavirus diseases including SARS-CoV and Middle East respiratory syndrome-related coronavirus (MERS-CoV) infection with varying efficacy [33]. CP was proven to be efficacious in patients with severe 2009 pandemic $\mathrm{H} 1 \mathrm{~N} 1 \mathrm{flu}$, reducing respiratory tract viral load, serum cytokine responses, length of hospital stay, and patient mortality [39]. CP therapy involves transfusing whole or fractionated plasma, collected from patients that have recently recovered from SARS-CoV-2 infection, to confer passive humoral immunity in people who are infected or at risk of infection $[29,40]$. Furthermore, CP therapy has advantages over other proposed treatment: it requires low technology (and therefore 
it can be produced where required independent of pharmaceutical companies), it is low cost and has strong biological plausibility, and it has potential for rapid development and deployment (production is easily scalable as long as there are sufficient donors) [41-43]. Accordingly, on March 24, 2020, the Food and Drug Administration (FDA) approved the use of $\mathrm{CP}$ therapy as an emergency investigational new drug to treat patients with serious or immediately life-threatening COVID-19 infections [44]. Subsequently, on August 23, 2020, the FDA issued an Emergency Use Authorization (EUA) for $\mathrm{CP}$ for treating COVID-19 [45]. According to the FDA regulation, the plasma must be collected from recovered patients who can donate blood, have had no symptoms for 14 days, and have had negative results on COVID-19 tests. Both single-donor and pooled immuno-globulin products currently prioritize collection of convalescent donor plasma with high levels of neutralizing antibodies. Based on the preliminary data from clinical trials and considering the United States National Institute of Health and FDA recommendation, remdesivir and $\mathrm{CP}$ are the most promising potential for COVID-19 treatment [46]. CP for treating COVID-19 is accessible via the regulatory pathways (investigational new drug regulatory pathway). Another is expanded access, also called "compassionate use" emergency Investigational New Drug Application (an investigational medical product), to treat patients [47]. It should be noted that, currently, Regeneron's REGN-COV2 and Lilly's LY- CoV555, both of which are cocktail therapies comprising receptor binding domain (RBD)-reactive antibodies, have also been granted EUA for COVID-19 by the FDA [48,49].

On the other hand, systematic reviews have been conducted for current medications that have been used for the treatment of COVID-19. A comparative analysis of three treatment modalities for COVID-19, chloroquine and hydroxychloroquine, $\mathrm{CP}$, and remdesivir, found that each modality had both favorable and unfavorable characteristics, but none showed clear evidence of benefit for early outpatient disease or prophylaxis; in particular, chloroquine or hydroxychloroquine is no longer a viable option [50], while CP therapy appeared to show clinical advantages for inpatient use [14]. Moreover, meta-analysis of the safety and efficacy of various interventions including the three treatments and dexamethasone or lopinavir-ritonavir showed that dexamethasone and remdesivir might be beneficial for patients with COVID-19, but the certainty of the evidence was low to very low, so more trials are needed [51].

Studies are currently underway to evaluate use of $\mathrm{CP}$ as treatment for patients with severe COVID-19 and to prevent infection (prophylaxis) in certain high-risk patients exposed to COVID-19. Currently, CP is being given to small numbers of hospitalized patients with severe or life-threatening COVID-19 illness [52]. Several case reports suggest treatment is helpful, but larger studies are still needed. Although there is a lot that is unknown, CP may work best for patients earlier in the disease course $[53,54]$. Therapy using CP may also be beneficial for prophylaxis against SARS-CoV-2 in individuals who are at high risk; there is considerable interest to leverage $\mathrm{CP}$ for frontline health care workers, first responders, other caregivers, and vulnerable individuals with underlying medical conditions $[55,56]$. This strategy has been previously used in SARS-CoV and MERS-CoV outbreaks [57]. Although the evidence for CP therapy remains inconclusive, preliminary trials for $\mathrm{CP}$ suggest that there may be some benefits, and there is growing consensus that $\mathrm{CP}$ is an important first-line immunotherapy for emerging viral infections when other specific treatments are not available [58]. Currently, several countries and health institutions are collecting $\mathrm{CP}$ for either empirical treatment or clinical trials $[55,59]$. However, research to date is at a high risk of bias, and randomized control trials are desperately needed to determine the efficacy and safety of this therapeutic option.

There are many ongoing trials and reviews, perspectives, commentaries, and guidelines published every day related to all aspects of COVID-19 CP, ranging from donor selection, plasma collection, testing, and storage to clinical use. In this paper, we sought to review all aspects of CP use for COVID-19, from detection of the level and activity of $\mathrm{CP}$ antibodies to appraisal of the quality and meta-analysis of original clinical studies of $\mathrm{CP}$ therapy, to characterize the knowledge gap and provide recommendations for future directions.

\section{Methods}

This systematic review was conducted in accordance with the PRISMA (Preferred Reporting Items for Systematic Reviews and Meta-Analyses) guidelines [60].

\section{Search Strategy}

We searched relevant databases including PubMed, Web of Science, and Embase from June 19, 2020, for published and unpublished trials with no limitations on starting date, with the terms COVID-19 OR SARS-CoV-2 OR "coronavirus* 2019" AND convalescent plasma/ser*; we continued the search and updated the review during the manuscript preparation until October 22, 2020. Both plasma and serum or sera have been used in the literature. In this review, plasma is representative for both terms.

\section{Data Abstraction}

Titles and abstracts were screened to determine relevance and, if deemed appropriate, the full article was reviewed. Additional publications were selected from the cross-references listed in the original papers and from the cited articles. Disagreements were resolved by consensus or with another review author. The same strategy was used for data extraction and study appraisal as described later.

\section{Study Eligibility Criteria}

Experimental (randomized controlled trials [RCTs], quasi-RCTs, non-RCTs), quasi-experimental (controlled before-after studies, interrupted time series), and observational (cohort, case-control) studies are eligible if they examined $\mathrm{CP}$ or serum for prevention, diagnosis, or treatment of COVID-19.

Review articles were excluded unless they were focused on or directly related to $\mathrm{CP}$ (eg, passive immunotherapy) for COVID-19. Papers on antibody detection and immunity were also excluded unless specifically related to $\mathrm{CP}$. 


\section{Data Extraction and Study Appraisal}

All literature search results were screened independently by two reviewers. The commentaries in support of the use of $\mathrm{CP}$ for COVID-19 were considered positive, those suggesting improvements in CP treatment were categorized as neutral, and precautions against $\mathrm{CP}$ were determined to be negative. The review type was determined according to a typology of reviews by Grant and Booth [61]. The quality appraisal of included clinical studies was conducted using the Effective Public Health Practice Project (EPHPP) Quality Assessment Tool [62]. Specifically, each clinical study was evaluated for the following components: sample selection, study design, identification and treatment of confounders, blinding of outcome assessors and participants, reliability and validity of data collection methods, and withdrawals and dropouts. The overall rate of each study was determined by assessing the six component ratings. Those with no weak ratings and at least 4 strong ratings were rated strong. Those with less than 4 strong ratings and 1 weak rating were considered moderate. Those with 2 or more weak ratings were rated weak.

\section{Analyses}

Studies were analyzed separately according to their design (case report, case series, observational, or randomized trials). Clinical and methodological heterogeneities across the studies were assessed by examining the details of the patients, the baseline data, the interventions, and the outcomes to determine whether the studies were sufficiently similar.

For disease severity, severe COVID-19 is a clinical situation in which the patient has dyspnea, tachypnea (respiratory rate $\geq 30$ breaths/minute), blood oxygen saturation $\leq 93 \%$ on room air, partial pressure of arterial oxygen to fraction of inspired oxygen ratio $<300 \mathrm{PaO}_{2} / \mathrm{FiO}_{2}<300$, or lung infiltrates $>50 \%$ within 24-48 hours on chest $\mathrm{x}$-ray [63]. Life-threatening disease is defined as respiratory failure, septic shock, or multiple organ dysfunction or failure [63].

Case and randomized controlled studies were combined in meta-analyses using Review Manager (Version 5.4, The Cochrane Collaboration). Data were pooled using an inverse variance method and analyzed using a random-effects model, as this approach accommodates clinical and statistical variations. Odds ratios (ORs) and 95\% CIs were used as statistical measures for mortality, clinical improvement, and viral clearance as a dichotomous outcome. Mean and SD were the statistical measure used to describe length of hospital stay. In studies that reported data in medians and IQRs, mean and SD were estimated using the sample size in each study arm, the medians, and the first and third IQRs as demonstrated in the method published by Wan et al [64]. Heterogeneity was determined using the $\mathrm{I}^{2}$ statistic and the chi-square test. High values of both tests $\left(\mathrm{I}^{2}>40 \%\right.$, a significant chi-square value with $\left.P<.05\right)$ demonstrate high levels of inconsistency and heterogeneity.

\section{Results}

\section{Overall Findings}

As illustrated in Figure 1, we reviewed 438 titles and abstracts and identified 243 manuscripts relevant to five areas of focus or types: (1) original clinical studies; (2) commentary in the form of letter to the editor, correspondence or editorial, brief communication, opinions, perspectives, and viewpoints; (3) review of the use of $\mathrm{CP}$; (4) protocol or guidance for clinical trials or production of $\mathrm{CP}$; and (5) in vitro testing of $\mathrm{CP}$.

A total of 243 articles were included in this review. As summarized in Table 1, they can be stratified as follows: 64 clinical studies (20 case reports, 31 case series, 11 case-control studies, and 2 RCTs), 79 commentary articles, 46 reviews, 19 guidance and protocols, and 35 in vitro testing of $\mathrm{CP}$ antibodies. 
Figure 1. PRISMA (Preferred Reporting Items for Systematic Reviews and Meta-Analyses) flow diagram. The literature search was conducted on June 19 and updated on October 22, 2020. The screening, full-text review, and extraction were managed online using Covidence. CP: convalscent plasma.

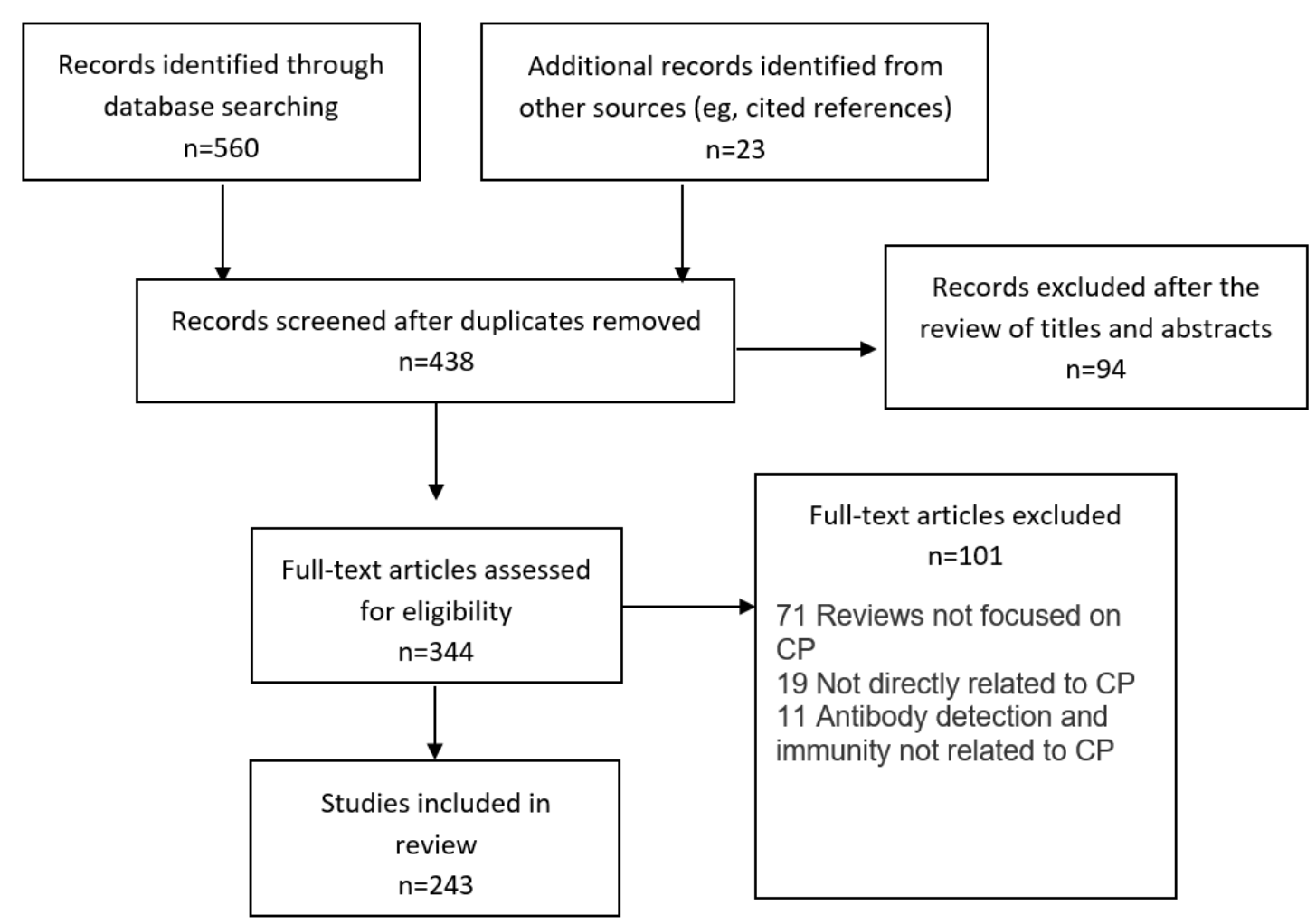


Table 1. Summary of literature.

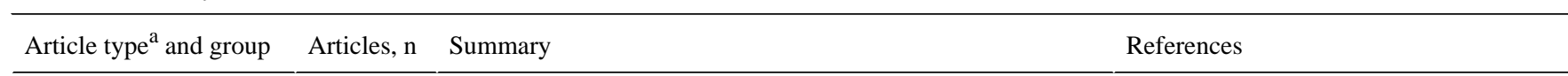

$\begin{array}{cc}\text { Clinical studies } & 64 \\ \text { Case reports } & \end{array}$

Case reports

Case series

Observational (cohort, case-control studies)
A single severe or critically ill COVID-19 patient of different ages (6-100 years), either previously healthy or with comorbidities (cancers, organ transplantation, immunodeficiency, hypertension, diabetes, cerebral hemorrhage, cardiopulmary disease, or pregnancy), was successfully treated with one or two doses of $\mathrm{CP}^{\mathrm{b}}$ (150-250 $\mathrm{mL}$ per dose; anti-SARS-CoV-2 IgG titer 1:13.3-1:700) in combination with antiviral or anti-inflammatory drugs (favipiravir and hydroxychloroquine, enoxaparin, methylprednisolone, remdesivir, lopinavir or ritonavir, prednisone), antibiotic therapy (azithromycin, ceftriaxone moxifloxacin, piperacillin, tienam), antifungal medication (fluconazole), or prophylactic low-molecular-weight heparin
- Al Helali et al 2020 [65]

- Anderson et al 2020 [66]

- Bao et al 2020 [67]

- Cinar et al 2020 [68]

- Clark et al 2020 [69]

- $\quad$ Figlerowicz et al 2020 [70]

- Grisolia et al 2020 [71]

- Hahn et al 2020 [72]

- Hartman 2020 [73]

- Im et al 2020 [74]

- Jafari et al 2020 [75]

- Jiang et al 2020 [76]

- Karataş et al 2020 [77]

- Khan et al 2020 [78]

- $\quad K o n g$ et al 2020 [79]

- $\quad$ Mira et al 2020 [80]

- Rodriguez et al 2020 [81]

- Soleimani and Soleimani 2020 [82]

- Xu et al 2020 [83]

- Zhang et al 2020 [84]

31 clinical studies involving two or more COVID-19 patients of different ages (14-91 years) and disease severity (eg, hospitalized, moderate, severe, or life-threatening), either previously healthy or with comorbidities (cancer, hypertension, immunosuppression, organ transplantation) that were treated with various doses of CP ( $200 \mathrm{~mL}$ to $3 \times 200 \mathrm{~mL})$ in addition to supportive care, antiviral therapy, antibiotics, steroids, or anticoagulation treatment.

- $\quad$ Ahn et al 2020 [85]

- Abdullah et al 2020 [86]

- Bradfute et al 2020 [87]

- Diorio et al 2020 [88]

- Enzmann et al 2020 [89]

- $\quad$ Erkurt et al 2020 [90]

- Fung et al 2020 [56]

- Gemici et al 2020 [91]

- Hartman et al 2020 [63]

- $\quad$ Ibrahim et al 2020 [92]

- Bobek et al 2020 [93]

- Jin et al 2020 [94]

- Joyner et al 2020 [95-97]

- Liu et al 2020 [98]

- $\quad$ Maor et al 2020 [99]

- Naeem et al 2020 [100]

- Olivares-Gazca et al 2020 [101]

- Pal et al 2020 [102]

- Rahman et al 2020 [103]

- Salazar et al 2020 [104]

- Shen et al 2020 [105]

- Tremblay et al 2020 [106]

- Wei et al 2020 [107]

- Wang et al 2020 [108]

- Wu et al 2020 [109]

- Xi et al 2020 [110]

- Ye et al 2020 [111]

- Zhang et al 2020 [112]

- $\quad$ Zeng et al 2020 [113]

11 cohort, case-control studies of a CP treatment group (6-316 patients) and a matched control (12-1430 patients) of severe or life-threatening COVID-19 patients to compare clinical and laboratory outcomes including all-cause mortality, total hospitalization days, and patients' need for intubation between the two groups.
Abolghasemi et al 2020 [114]

- Duan et al 2020 [115]

- Hegerova et al 2020 [116]

- $\quad$ Liu et al 2020 [117]

- Perotti et al 2020 [118]

- Rasheed et al 2020 [119]

- Roger et al 2020 [120]

- Salazar et al 2020 [121]

- Xia et al 2020 [122]

- Xiao et al 2020 [123]

- Zeng et al 2020 [124] 


\begin{tabular}{|c|c|c|c|}
\hline Article type ${ }^{\mathrm{a}}$ and group & Articles, $\mathrm{n}$ & Summary & References \\
\hline $\mathrm{RCT}^{\mathrm{c}}$ & & $\begin{array}{l}\text { Two RCTs of } 86 \text { hospitalized and } 103 \text { severe or life-threatening } \\
\text { COVID-19 patients randomized at } 1: 1 \text { ratio for standard of care } \\
\text { therapy with and without CP. The primary outcome was mortal- } \\
\text { ity and time to clinical improvement. }\end{array}$ & $\begin{array}{l}\text { - } \quad \text { Gharbharan et al } 2020 \text { [125] } \\
\text { Li et al } 2020 \text { [126] }\end{array}$ \\
\hline
\end{tabular}

Commentary (corre-

79

spondence, editorial,

letter to the editor,

opinions, perspectives,

viewpoints) 


\begin{tabular}{|c|c|c|c|}
\hline Article type ${ }^{\mathrm{a}}$ and group & Articles, n & Summary & References \\
\hline Positive & & $\begin{array}{l}\text { These are commentaries that supported clinical use and evalua- } \\
\text { tion of CP for COVID- } 19 \text { treatment based on the unique im- } \\
\text { munomodulatory properties of CP and historical and current } \\
\text { data for its safety and efficacy against coronaviruses including } \\
\text { SARS-CoV-2 but suggested limitations, future clinical investi- } \\
\text { gations, and a variety of aspects to be considered for the optimal } \\
\text { use of CP for COVID-19 including CP donor selection, CP } \\
\text { collection and testing, manufacturing turnaround time, cost and } \\
\text { the logistics of storage, distribution, treatment population, and } \\
\text { administration timing and dosing. }\end{array}$ & 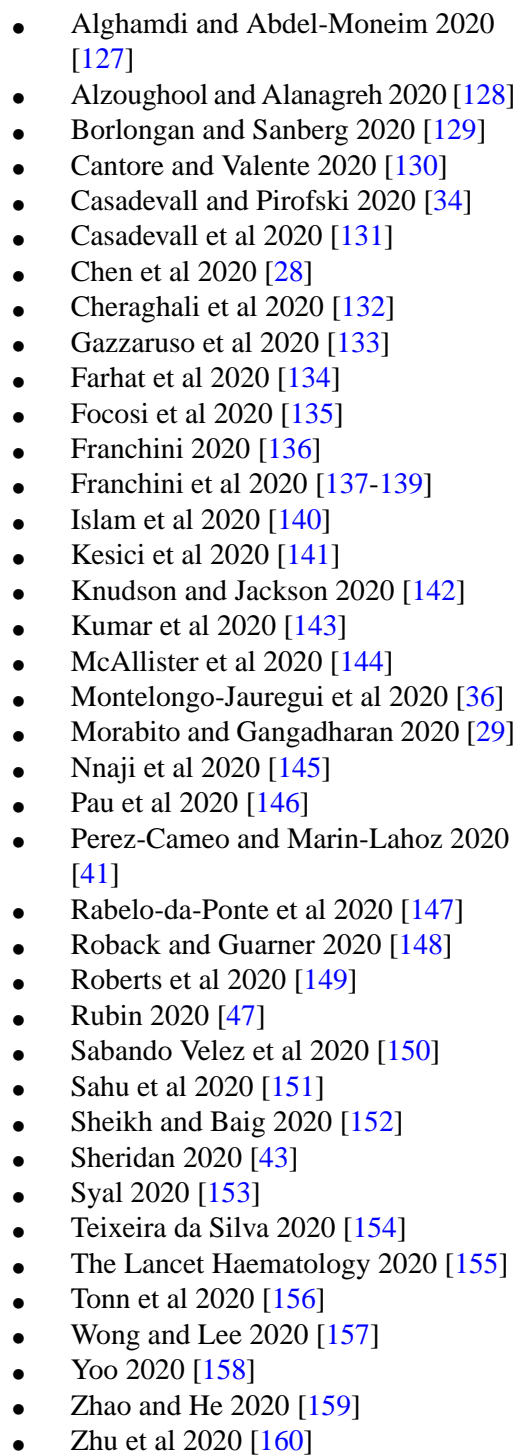 \\
\hline
\end{tabular}




\begin{tabular}{|c|c|c|c|}
\hline Article type ${ }^{\mathrm{a}}$ and group & Articles, $\mathrm{n}$ & Summary & References \\
\hline & & & 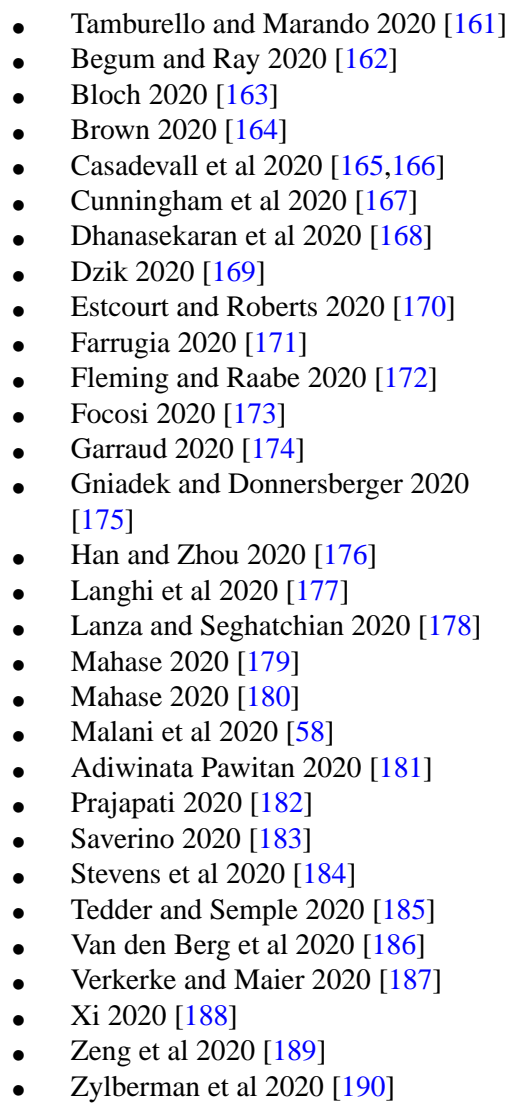 \\
\hline Negative & & $\begin{array}{l}\text { This group of commentaries suggested that the risks associated } \\
\text { with CP use (eg, adverse effects and blood-borne pathogen } \\
\text { transmission) outweighed its benefits or other therapeutics for } \\
\text { COVID-19. }\end{array}$ & $\begin{array}{ll}\text { - } & \text { Caccamo et al } 2020[191] \\
\text { - } & \text { Ferreira and Mostajo-Radji 2020 [192] } \\
\text { - } & \text { Joob and Wiwanitkit 2020 [193] } \\
\text { - } & \text { Sanfilippo et al } 2020[194,195] \\
\text { - } & \text { Wiwanitkit 2020 [196] }\end{array}$ \\
\hline Review & 46 & $\begin{array}{l}46 \text { different types of reviews (a total of } 10 \text { review types with } \\
\text { unique features in terms of prescribed and explicit methodolo- } \\
\text { gies) on CP for treatment of virus infectious diseases (eg, } \\
\text { SARS }^{\text {d }} \text {, MERS }{ }^{\text {e }} \text {, EBOV } \\
\text { f, and H1N1) and COVID-19 with } \\
\text { safety and efficacy as main outcomes and recommendations. } \\
\text { Some reviews also covered other aspects related to CP use, such } \\
\text { as SARS-CoV-2 immunology, mechanism of action, CP donor } \\
\text { selection, CP collection, pooling technologies, pathogen inacti- } \\
\text { vation systems, banking of CP, timing and dose of CP treatment, } \\
\text { patient selection, risk-benefit analysis, and list of ongoing reg- } \\
\text { istered clinical trials. }\end{array}$ & \\
\hline
\end{tabular}




\begin{tabular}{|c|c|c|c|}
\hline Article type ${ }^{\mathrm{a}}$ and group & Articles, $\mathrm{n}$ & Summary & References \\
\hline Rapid review & & & $\begin{array}{l}\text { - } \quad \text { Barone and DeSimone } 2020 \text { [197] } \\
\text { - } \quad \text { Majbour and El-Agnaf } 2020 \text { [198] }\end{array}$ \\
\hline $\begin{array}{l}\text { State-of-the-art re- } \\
\text { view }\end{array}$ & & & $\begin{array}{l}\text { - Brown and McCullough } 2020 \text { [199] } \\
\text { - Focosi et al } 2020 \text { [27] }\end{array}$ \\
\hline Scoping review & & & $\begin{array}{l}\text { - Cao and Shi } 2020[200] \\
\text { - Zheng et al } 2020[201]\end{array}$ \\
\hline $\begin{array}{l}\text { Review of the evi- } \\
\text { dence }\end{array}$ & & & $\begin{array}{ll}\text { - } & \text { de Alwis et al } 2020 \text { [202] } \\
\text { - } & \text { Fischer et al } 2020 \text { [203] } \\
\text { - } & \text { Mucha and Quraishy } 2020 \text { [204] }\end{array}$ \\
\hline $\begin{array}{l}\text { Systematic review } \\
\text { and meta-analysis }\end{array}$ & & & $\begin{array}{ll}\text { - } & \text { Chai et al } 2020 \text { [205] } \\
\text { - } & \text { Devasenapathy et al 2020 [206] } \\
\text { - } & \text { Piechotta et al 2020 [207] } \\
\text { - } & \text { Sarkar et al 2020 [208] } \\
\text { - } & \text { Sun et al 2020 [209] }\end{array}$ \\
\hline Overview & & & $\begin{array}{ll}\text { - } & \text { Abdollahi et al } 2020[210] \\
\text { - } & \text { Annamaria et al 2020 [211] } \\
\text { - } & \text { Anudeep et al } 2020[212] \\
\text { - } & \text { Bloch et al 2020 [55] } \\
\text { - } & \text { Gasparyan Kum et al 2020 [213] } 2020[214] \\
\text { - } & \text { Iftikhar et al 2020 [215] } \\
\text { - } & \text { Li et al 2020 [216] } \\
\text { - } & \text { Lindholm et al 2020 [217] } \\
\text { - } & \text { Murphy et al 2020[218] } \\
\text { - } & \text { Sayinalp et al 2020 [219] } \\
\text { - } & \text { Subbarao et al 2020[220] }\end{array}$ \\
\hline $\begin{array}{l}\text { Mixed studies re- } \\
\text { view }\end{array}$ & & & - $\quad$ Pawar et al 2020 [221] \\
\hline Systematic review & & & $\begin{array}{ll}\text { - } & \text { Bakhtawar et al } 2020 \text { [222] } \\
\text { - } & \text { Chen and Xia } 2020 \text { [223] } \\
\text { - } & \text { Rajendran et al 2020 [224] } \\
\text { - } & \text { Woolk et al 2020 [225] } \\
& \text { Wooding and Bach 2020 [57] }\end{array}$ \\
\hline Critical review & & & $\begin{array}{ll}\text { - } & \text { Focosi and Farrugia } 2020 \text { [226] } \\
\text { - } & \text { Nagoba et al } 2020[227] \\
\text { - } & \text { Tibaltopoulou et al } 2020 \text { [228] } \\
\text { Tien et al } 2020[59]\end{array}$ \\
\hline Literature review & & & $\begin{array}{ll}\text { - } & \text { Choi } 2020 \text { [52] } \\
\text { - } & \text { Khulood et al 2020 [229] } \\
\text { - } & \text { Chua Vi Long et al 2020 [230] } \\
\text { - } & \text { Ouyang et al 2020 [231] } \\
\text { - } & \text { Piyush et al 2020 [232] } \\
\text { - } & \text { Rojas et al 2020 [233] } \\
\text { - } & \text { Selvi 2020 [234] } \\
\text { - } & \text { Sullivan an and Roback 2020 [236] } \\
\text { - } & \text { Yigenoglu et al 2020 [237] }\end{array}$ \\
\hline Protocol/guidance & 19 & $\begin{array}{l}\text { These are protocols for clinical trials to evaluate the safety and } \\
\text { efficacy of CP in treating COVID- } 19 \text { patients, guidelines or } \\
\text { programs for CP donor selection, CP preparation, laboratory } \\
\text { examination, storage, distribution, dose, frequency and timing } \\
\text { of CP administration, targeted patients, parameters to assess } \\
\text { response to the treatment and long - term outcome, adverse } \\
\text { events, and CP application in resource-limited countries and in } \\
\text { pediatrics and neonates. }\end{array}$ & \\
\hline
\end{tabular}




\begin{tabular}{|c|c|c|}
\hline Article type ${ }^{\mathrm{a}}$ and group & Articles, $\mathrm{n} \quad$ Summary & References \\
\hline $\begin{array}{l}\text { Preparation/produc- } \\
\text { tion of } \mathrm{CP}\end{array}$ & & - Accorsi et al 2020 [238] \\
\hline $\begin{array}{l}\text { Protocol for a non- } \\
\text { randomized trial }\end{array}$ & & - Albalawi et al 2020 [239] \\
\hline $\begin{array}{l}\text { Clinical study and } \\
\text { application of CP }\end{array}$ & & - Al-Riyami et al 2020 [240] \\
\hline $\begin{array}{l}\text { Conceptual frame- } \\
\text { work }\end{array}$ & & - Albahri et al 2020 [241] \\
\hline $\begin{array}{l}\text { Expert opinion, sur- } \\
\text { vey of group mem- } \\
\text { bers, and review of } \\
\text { available evidence }\end{array}$ & & - $\quad$ Bloch et al 2020 [242] \\
\hline $\begin{array}{l}\text { COVID-19 CP pro- } \\
\text { gram }\end{array}$ & & $\begin{array}{ll}\text { - } & \text { Blackall et al } 2020 \text { [243] } \\
\text { - } & \text { Budhai et al } 2020 \text { [244] }\end{array}$ \\
\hline $\begin{array}{l}\text { Study protocol for } \\
\text { RCTs }\end{array}$ & & $\begin{array}{ll}\text { - } & \text { Chowdhury et al } 2020 \text { [245] } \\
\text { - } & \text { Eckhardt et al } 2020 \text { [246] } \\
\text { - } & \text { Janssen et al } 2020 \text { [247] }\end{array}$ \\
\hline $\begin{array}{l}\text { Perspective docu- } \\
\text { ment of the Working } \\
\text { Party on Global } \\
\text { Blood Safety of the } \\
\text { International Society } \\
\text { of Blood Transfu- } \\
\text { sion }\end{array}$ & & - $\quad$ Epstein and Burnouf 2020 [248] \\
\hline Commentary & & - Epstein et al 2020 [249] \\
\hline $\begin{array}{l}\text { Guidance for treat- } \\
\text { ing early to moder- } \\
\text { ate COVID-19 pa- } \\
\text { tients with CP }\end{array}$ & & - Hassan et al 2020 [250] \\
\hline $\begin{array}{l}\text { Initiative for provi- } \\
\text { sion of } \mathrm{CP}\end{array}$ & & - $\quad$ Ipe et al 2020 [251] \\
\hline $\begin{array}{l}\text { A pilot program of } \\
\mathrm{CP} \text { collection }\end{array}$ & & - $\quad$ Li et al 2020 [252] \\
\hline $\begin{array}{l}\text { Strategy and experi- } \\
\text { ence }\end{array}$ & & - $\quad$ Pei et al 2020 [253] \\
\hline $\begin{array}{l}\text { One arm proof-of- } \\
\text { concept clinical trial } \\
\text { protocol }\end{array}$ & & - $\quad$ Perotti et al 2020 [254] \\
\hline $\begin{array}{l}\text { An apheresis re- } \\
\text { search project pro- } \\
\text { posal }\end{array}$ & & - $\quad$ Seghatchian and Lanza 2020 [255] \\
\hline $\begin{array}{l}\text { Authority guide by } \\
\text { Turkish Ministry of } \\
\text { Health }\end{array}$ & & - Yilmaz et al 2020 [256] \\
\hline $\begin{array}{l}\text { In vitro testing of conva- } \\
\text { lescent plasma }\end{array}$ & 35 & \\
\hline
\end{tabular}




\begin{tabular}{l}
\hline Article type $^{\mathrm{a}}$ and group \\
\hline ELISA $^{\mathrm{g}}$ with virus \\
antigens (eg, spike $^{\mathrm{h}}$ and $\mathrm{NP}^{\mathrm{h}}$ protein se- \\
quences) or recombi- \\
nant ACE-2 ${ }^{\mathrm{i}}$ as sub- \\
strates \\
\\
Pseudovirus capture \\
assay, VN ${ }^{\mathrm{k}}$ assay \\
using SARS-CoV-2 \\
strains and Vero-E6 \\
cells
\end{tabular}

Immunoassays for anti-SARS-CoV-2 $\mathrm{IgM}, \mathrm{IgG}$, and IgA based on SARSCoV-2 SP

PCR-based tests

$\mathrm{VN}$ assays based on pseudotyped and live SARS-CoV-2 virus, and anti-SARS-CoV-2 $\mathrm{IgM}, \mathrm{IgG}$, and $\operatorname{Ig} \mathrm{A}$ ELISA based on virus antigens and ACE-2

\footnotetext{
Biophysical antibody profiling
}

\section{Articles, $\mathrm{n}$ Summary}

An ELISA could be a high-throughput competitive assay to detect different antibody types against SARS-CoV-2 in serum and plasma from convalescent patients; to estimate the neutralizing capacity of antispike protein antibodies to block interaction with the human ACE-2 required for viral entry; and to identify candidate sera for therapeutic use. A combination of antigenic targets (NP, spike protein, $\left.\mathrm{S}^{-\mathrm{RBD}^{j}}\right)^{\mathrm{j}}$ may improve the accuracy of $\operatorname{IgG}$ detection in $\mathrm{CP}$ donors.

In vitro evaluation of CP potency for COVID-19 treatment could be measured by its binding capacity to the SARS-CoV2 spike protein and neutralizing activity against pseudotyped and chimeric viruses and authentic SARS-CoV-2, which is useful to identify donors with high titers for CP for COVID-19 therapy. There were individual differences in the antibody level (neutralizing antibody titers $<1: 16$ to $>1: 1024$ ) and its changes over 12-60 days since onset of symptoms among representative convalescent patients.

$\mathrm{CP}$ collected from adults who met all criteria for donating blood had confirmed COVID-19 by positive SARS-CoV- $2 \mathrm{PCR}^{\mathrm{m}}$ test and completed resolution of symptoms at least 14 days prior to donation showed a wide range of antibody levels. Total anti-SARS-CoV-2 NP antibody strength correlated with time from symptom resolution to sample collection and symptom duration. There was a decline in the $\operatorname{IgG}$ level over a short duration of 10 days. $\mathrm{RBD}^{\mathrm{n}}$-specific serum $\operatorname{IgG}, \operatorname{IgM}$, and $\operatorname{IgA}$ COVID-19 convalescent patients continued to decline from 28 to 99 days after hospital discharge. Anti-SARS-CoV-2 spike protein IgG antibody strength correlated with age and hospitalization for COVID-19.

SARS-CoV-2 neutralizing antibodies were detectable as early as 10 days after onset of symptoms and continue to rise, plateauing after 18 days and were not altered by amotosalen and UV-A radiation to inactivate potentially contaminating infectious pathogens in CP. Detectable viral RNA in older COVID-19 patients screened for CP donation even 12-24 days after symptom resolution.

The levels of anti-SARS-CoV-2 IgM, IgG, and IgA and the neutralization capacity of $\mathrm{CP}$ showed a wide range and changed over time after the onset of COVID-19 symptoms and declined within the first 3 months following diagnosis, suggesting an optimal time period for $\mathrm{CP}$ collection. Both could be associated with donor's age, sex, weight, COVID-19 severity, days between disease onset and plasma collection. There were various degrees of positive correlations (coefficients 0.21-0.87) between the $\mathrm{VN}$ and ELISA results. Some commercial ELISA can perform effectively as surrogate assays for predicting neutralizing antibody titres.

\section{References}

- $\quad$ Amanat et al 2020 [257]

- Byrnes et al 2020 [258]

- $\quad$ Gattinger et al 2020 [259]

- $\quad$ Zhang et al 2020 [84]

- DomBourian et al 2020 [260]

Ding et al 2020 [261]

- $\quad$ Ianevski et al 2020 [262]

- $\quad$ Schmidt et al 2020 [263]

- Wang et al 2020 [264]

- Muruato et al 2020 [265]
- $\quad$ Ragnesola et al 2020 [266]

- $\quad$ Yang et al 2020 [267]

- de Assis et al 2020 [268]

- Dulipsingh et al 2020 [269]

- Ikegami et al 2020 [270]

- $\quad$ Ma et al 2020 [271]
- Danh et al 2020 [272]

- Hartman et al 2020 [273]

\section{Abe et al 2020 [274]}

Beaudoin-Bussières et al 2020 [275]

Benner et al 2020 [276]

- Boonyaratanakornkit et al 2020 [277]

- $\quad$ Gniadek et al 2020 [278]

- $\quad$ Patel et al 2020 [279]

- Harvala et al 2020 [280]

- Wendel et al 2020 [281]

- $\quad$ Zeng et al 2020 [282]

- Dogan et al 2020 [283]

- Jungbauer et al 2020 [284]

- $\quad$ Li et al 2020 [285]

- $\quad$ Ni et al 2020 [286]

- Robbiani et al 2020 [287]

- $\quad$ Salazar et al 2020 [288]

- Weidner et al 2020 [289]

- $\quad$ Natarajan et al 2020 [290]

$\mathrm{CP}$ antibodies can elicit Fc-dependent functions beyond viral neutralization such as complement activation, phagocytosis, and antibody-dependent cellular cytotoxicity against SARSCoV-2.

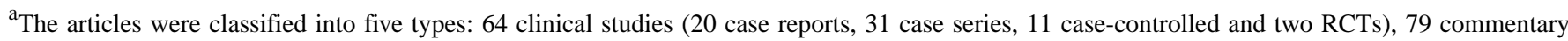
articles, 46 reviews, 19 guidance and protocols, and 35 in vitro testing of CP antibodies. The details are shown in Table S1 in Multimedia Appendix 1. ${ }^{\mathrm{b}} \mathrm{CP}$ : convalescent plasma.

${ }^{\mathrm{c}} \mathrm{RCT}$ : randomized controlled trial.

${ }^{\mathrm{d}}$ SARS: severe acute respiratory syndrome.
} 
${ }^{\mathrm{e}}$ MERS: Middle East respiratory syndrome.

${ }^{f}$ EBOV: Ebola virus.

${ }^{g}$ ELISA: enzyme-linked immunosorbent assay.

${ }^{\mathrm{h}} \mathrm{NP}$ : nucleocapsid protein.

${ }^{\mathrm{i}} \mathrm{ACE} 2$ : angiotensin converting enzyme 2 .

${ }^{\mathrm{j}} \mathrm{S}-\mathrm{RBD}$ : spike protein receptor-binding domain.

${ }^{\mathrm{k}} \mathrm{VN}$ : virus neutralization.

${ }^{1}$ SP: spike protein.

${ }^{m}$ PCR: polymerase chain reaction.

${ }^{\mathrm{n}} \mathrm{RBD}$ : receptor-binding domain.

All clinical studies are therapeutic use of $\mathrm{CP}$ focusing on safety and efficacy, and they are further reviewed in the following section. The commentaries cover various aspects of $\mathrm{CP}$, ranging from critiques of clinical studies [131,137,148,163,176,189] and literature review $[145,221]$ to the stability of antibodies in CP [156,291], relevant news [180], and a response letter [164], while a majority focused on the safety and efficacy of CP. Most commentaries were in favor of CP therapy for COVID-19, recognizing the need for more high-quality evidence from large and well-designed clinical trials to show its efficacy, and other issues (eg, CP collection) still need to be addressed. Some commentaries proposed alternative or complementary CP-based approaches to COVID-19 that possess fewer risks [178,182] but may not be immediately available for clinical use. Only a few commentaries put more emphases on the potential risks over benefits of CP therapy [191-194,196].

In a particular correspondence, a metadata analysis of the efficacy of CP treatment based on 9 clinical studies (mostly case series) suggested that $\mathrm{CP}$ reduced viral loads (risk ratio $0.13,95 \%$ CI $0.09-0.18 ; P<.001 ; \mathrm{n}=75)$ and C-reactive protein levels (ratio of mean [ROM] 0.11, 95\% CI 0.01-0.86; $P<.05$; $\mathrm{n}=42$ ), and improved the clinical status of patients with COVID-19 (ROM 0.53, 95\% CI 0.36-0.79; $P<.01 ; \mathrm{n}=149$ ) when compared to baseline (date of CP transfusion) [147]. In addition, the effects of $\mathrm{CP}$ on $\mathrm{C}$-reactive protein levels and clinical improvement were not associated with the patient's age and the use of antivirals, antibiotics, and hydroxychloroquine. Several commentary papers and reviews advocated for the rationale of developing fast access to $\mathrm{CP}$ collection and treatment of patients with COVID-19 [34,47,59,148,199,229]. Among the reviews, most were descriptive overviews of existing literature and recommendations for clinical use and trial without any search strategies. Few were conducted following the PRISMA guidelines [222,224,225]. It is noteworthy that 1 systematic review and meta-analysis was on the safety and efficacy of $\mathrm{CP}$ therapy for other severe respiratory viral infections to provide indirect evidence for CP therapy for COVID-19 [206], and another 2 systematic reviews and meta-analyses were on completed and ongoing clinical studies on the safety and efficacy of $\mathrm{CP}$ or hyperimmune immunoglobulin transfusion in the treatment of COVID-19 [207,208]. One review and meta-analysis included 20 studies (1 RCT, 3 controlled nonrandomized studies of interventions, 16 noncontrolled nonrandomized studies of interventions) with 5443 participants [207]. The meta-analysis of 4 controlled studies (1 RCT and 3 controlled nonrandomized studies of interventions) with 339 patients could not support any effects of CP treatment on all-cause mortality at hospital discharge, time to death, or improvement of clinical symptoms at 7 days. The review also investigated the safety of CP based on 14 studies (5201 participants, with 5000 participants from 1 noncontrolled nonrandomized studies of intervention) and found very low-certainty evidence for safety. The review was recently updated, which included 19 studies with 36,081 patients treated by CP, and made the same conclusion [205]. The other review included 7 studies, including 2 RCTs and 5 cohort studies, with a total of 5444 patients [208]. The meta-analysis indicated that $\mathrm{CP}$ therapy reduced mortality and increased viral clearance and clinical improvement. It confirmed the safety of $\mathrm{CP}$ transfusion with very low incidence of serious adverse events. However, the risk of bias and quality assessment in both reviews indicated that the evidence for the efficacy and safety of CP therapy was of low quality, suggesting the need for a large well-designed RCT. In addition, a survey has been conducted for current registered clinical trials of CP therapy for COVID-19, including a description of their characteristics such as study design, patient populations, outcomes, eligibility criteria for $\mathrm{CP}$ donors, $\mathrm{CP}$ collection, antibody titer, and CP dose [218].

Protocols, programs, and standards have been developed to select donors and collect, process, characterize, store, distribute, and apply CP to patients in need [238,240,242,250], and to conduct clinical trials [239,246,247,254]. Regional and national programs for COVID-19 CP have been established [243,244] as well as a multi-criteria decision-making frame for both $\mathrm{CP}$ donor and receipt selection [241].

Some key findings and implications from the in vitro testing studies of CP antibodies should be considered: a variety of methods have been developed to measure $\mathrm{CP}$ antibody titers including gold standard neutralization assay using living SARS-Cov-2 [261,262]; enzyme-linked immunosorbent assay (ELISA) using the antigens derived from the virus, mostly in a microplate platform $[257,258]$ and a few in lateral flow [266], microsphere [267], and microarray platforms [268]; and other methods (eg, polymerase chain reaction [PCR] tests) [272,273]. A number of studies showed a wide range of levels and neutralizing activities of anti-SARS-CoV-2 [264,267,289]. The neutralizing antibody levels declined within the first 3 months following diagnosis, suggesting a short optimum time window for the collection of $\mathrm{CP}$ with high neutralizing antibody titers [280]. A significant decrease was also observed in the antibody binding to the spike protein of SARS-CoV-2 and neutralizing capacity of plasma from convalescent donors at 6 and 10 weeks after symptoms onset [261]. The short duration of neutralizing antibody titers within months may have important implications 
for immunity and ongoing efforts to deploy CP for prevention and therapy of COVID-19 [165]. There is a significant correlation to various extents between ELISA-measured immunoglobulin (IgG) titer and neutralizing antibody titer [87,257,274,276,278-280,283-285,288,289]. However, the ELISA-determined anti-SARS-CoV-2 IgG did not always inhibit the virus receptor binding [259]. Antibody binding to SARS-CoV-2 spike glycoprotein as measured by pseudovirus capture assay did not always translate into neutralization [261].

Highly sensitive and specific platforms for the detection of anti-SARS-CoV-2 antibodies are becoming increasingly important for evaluating potential CP donors and identifying individuals with seroconversion [292]. Various platforms demonstrate significant correlations with a SARS-CoV-2 plaque reduction neutralization assay, suggesting their use for screening of individuals who have recovered from SARS-CoV-2 infections. Notably, a novel multiplexed solid-phase chemiluminescence immunoassay has been developed and commercially available from Meso Scale Discovery for simultaneous detection of IgG binding to four SARS-CoV-2 antigens (trimeric spike, spike RBD, spike $\mathrm{N}$ terminal domain, and nucleocapsid antigen) and the quantification of antibody-induced angiotensin-converting enzyme 2 (ACE-2) and ACE-2-binding inhibition (pseudo-neutralization assay) [293].

In addition to neutralization and immune assays, biophysical and functional evaluation of $\mathrm{CP}$ showed that it may have diverse antiviral effects against SARS-CoV-2 beyond neutralization, namely, antibody-dependent cellular cytotoxicity, phagocytosis, and complement activation [290]. Moreover, CP could act not only on the viral infection but also on the antithrombin deficiency to reduce thromboembolic events [133].

\section{Findings of Clinical Studies}

As summarized in Table 2, there are considerable heterogeneities among the clinical studies in terms of the populations, the amount of CP received, and a variety of comparators. The CP therapy studies differed in the following aspects: patient demographics (eg, age, gender, and comorbidities), donors' selection (ie, age, gender, diagnosis of SARS-CoV-2 infection and of recovery, and anti-SARS-CoV-2 antibody titer required for plasma donation), plasma collection and biologic qualification (number, volume and frequency of donations, infectious disease markers, and pathogen inactivation), and treatment and disease characteristics (dose and timing of administration, stage of the disease at which to start $\mathrm{CP}$ treatment). 
Table 2. Summary of original clinical studies of CP therapy for COVID-19. The studies were stratified according to the study design.

\begin{tabular}{llll}
\hline Study design and studies & Population & Details of $\mathrm{CP}^{\mathrm{a}}$ & $\begin{array}{l}\text { Interventions and com- } \\
\text { parisons }\end{array}$
\end{tabular}

\section{Case report}

Al Helali et al 2020 [65]

A previously healthy male 55 years of age with severe COVID-19

Anderson et al 2020 [66]

Bao et al 2020 [67]

Cinar et al $2020[68]$

Clark et al 2020 [69]

Figlerowicz et al 2020 [70] years of age infected by sis, and kidney failure
A pregnant critically ill Not reported female 35 years of age with COVID-19 and past medical history for type 2 diabetes mellitus, asthma, and class III obesity

A critically ill man 38 Not reported SARS-CoV-2 and had cerebral hemorrhage

A male patient 55 years of age with severe COVID-19 and active myeloid malignancy, disseminated tuberculo-

Immunocompromised woman 76 years of age with persisting COVID - 19 following therapeutic lymphocyte depletion

A girl 6 years of age with severe COVID-19

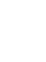

Collected using Trima Accel Automated Blood Collection System from a donor who had previously recovered from COVID-19 and met universal donation criteria, anti-SARS-CoV-2 IgG titer 6.6

Not reported
About $300 \mathrm{~mL}$ CP was transfused over $1 \mathrm{~h}$ in addition to other therapeutics: favipiravir, hydroxychloroquine, enoxaparin, paracetamol, diphenhydramine

One unit of $\mathrm{CP}$ on the day of admission at $\mathrm{ICU}^{\mathrm{c}}$ and supportive care and therapeutic agents

150-200 ml CP of type A Rh positive was given twice 9 days after hospital admission in addition to antiviral and antibacterial treatment

$200 \mathrm{~mL}$ of $\mathrm{CP}$ on fifth day of symptom onset and another $200 \mathrm{~mL}$ of $\mathrm{CP}$ at ICU, in combination with antiviral and anticytokine drugs
A significant radiological and clinical improvement in a few days after $\mathrm{CP}$ transfusion and negative $\mathrm{PCR}^{\mathrm{b}}$ test for COVID-19 in $<48 \mathrm{~h}$ and discharged 12 days post transfusion

CP transfused at day 50 after symptom onset over 2 days (200 $\mathrm{mL} /$ day) in addition to treatment with lopinavir/ritonavir and prednisone

$\mathrm{CP}$ inactivated using methylene blue with anti-SARS$\mathrm{CoV}-2 \mathrm{IgG}$ at a titer of 1:700 test; discharged on day
CP transfused once in a 200-mL dose at 5 weeks from the beginning of the disease and treatment with antiviral drugs and immune modulators, antibiotics, and antifungal drugs
Discharged on day 14 with no further issues afterward and continuing antenatal care with both primary obstetric office and maternal fetal medicine specialists

Both SARS-CoV-2 nucleic acid tests were negative (24 h interval) 2 days after the transfusion, and the patient's symptoms gradually stabilized

SARS-CoV-2 was negative, discharged from the hospital with full recovery

Not reported

Not reported

No adverse reaction or complication

No adverse events health condition, allowing definitively withdrawing oxygen, apyrexia ensued, and negative SARS-CoV-2 69

SARS-CoV-2 was negative for the next 3

No adverse events weeks after $\mathrm{CP}$ therapy. The hematologic parameters did not improve after SARS-CoV-2 elimination.

No significant adverse effects 


\begin{tabular}{|c|c|c|c|c|c|}
\hline Study design and studies & Population & Details of $\mathrm{CP}^{\mathrm{a}}$ & $\begin{array}{l}\text { Interventions and com- } \\
\text { parisons }\end{array}$ & $\begin{array}{l}\text { Outcomes/main find- } \\
\text { ings }\end{array}$ & $\begin{array}{l}\text { Adverse events } \\
\text { related to } \mathrm{CP} \\
\text { therapy }\end{array}$ \\
\hline Grisolia et al 2020 [71] & $\begin{array}{l}\text { A woman } 29 \text { years of } \\
\text { age at } 242 / 7 \text { weeks of } \\
\text { gestation }\end{array}$ & Not reported & $\begin{array}{l}\text { The patient was trans- } \\
\text { fused with } 300 \mathrm{~mL} \text { of } \\
\mathrm{CP} \text { on day } 7 \text { from onset } \\
\text { of symptoms and anoth- } \\
\text { er } 300 \mathrm{~mL} \text { of CP on day } \\
\text { 12, and treated with an- } \\
\text { tibiotics, low-molecu- } \\
\text { lar-weight heparin, hy- } \\
\text { droxychloroquine, and } \\
\text { methylprednisolone }\end{array}$ & $\begin{array}{l}\text { The patient's clinical } \\
\text { condition rapidly im- } \\
\text { proved as shown by } \\
\text { normalization of labora- } \\
\text { tory tests, body temper- } \\
\text { ature, } \mathrm{O}_{2} \text { saturation, } \\
\text { and vital signs within } 3 \\
\text { days of the second } \mathrm{CP} \\
\text { transfusion, discharged } \\
13 \text { days after admission }\end{array}$ & $\begin{array}{l}\text { No adverse ef- } \\
\text { fects }\end{array}$ \\
\hline Hahn et al 2020 [72] & $\begin{array}{l}\text { A previously healthy } \\
\text { man in his } 70 \text { s with se- } \\
\text { vere COVID-19 admit- } \\
\text { ted to ICU }\end{array}$ & $\begin{array}{l}\text { Obtained from two } \\
\text { blood donors with } \\
\text { one being diag- } \\
\text { nosed with high- } \\
\text { level anti-SARS- } \\
\text { CoV-2 IgG anti- } \\
\text { body }\end{array}$ & $\begin{array}{l}\text { A total of } 900 \mathrm{ml} \text { of CP } \\
\text { was transfused at a slow } \\
\text { infusion rate on day } 31 \\
\text { after admission and } \\
\text { treatment with a respira- } \\
\text { tor, muscle relaxants, } \\
\text { and antibiotics }\end{array}$ & $\begin{array}{l}\text { The patient became } \\
\text { afebrile and was tested } \\
\text { negative for SARS- } \\
\text { CoV-2 the following } \\
\text { day after CP therapy, } \\
\text { gradually improved and } \\
\text { was weaned from the } \\
\text { ventilator and dis- } \\
\text { charged alive from the } \\
\text { ICU on day } 63\end{array}$ & Not reported \\
\hline Hartman et al 2020 [73] & $\begin{array}{l}\text { A man } 62 \text { years of age } \\
\text { with a history of moder- } \\
\text { ate persistent asthma, } \\
\text { sinus bradycardia, } \\
\text { chronic obstructive pul- } \\
\text { monary disease, and } \\
\text { newly diagnosed } \\
\text { COVID-19 }\end{array}$ & Not reported & $\begin{array}{l}\text { The patient received } \\
217 \mathrm{~mL} \text { of } \mathrm{CP} \text { with no } \\
\text { other interventions at } \\
\text { the time estimated } 7 \\
\text { days after onset of } \\
\text { symptoms (cough and } \\
\text { shortness of breath) }\end{array}$ & $\begin{array}{l}\text { The patient showed } \\
\text { rapid improvement in } \\
\text { symptoms and electro- } \\
\text { cardiogram findings, } \\
\text { and was discharged } 36 \\
\text { hours after the transfu- } \\
\text { sion }\end{array}$ & Not reported \\
\hline Im et al 2020 [74] & $\begin{array}{l}\text { A man } 68 \text { years of age } \\
\text { with severe COVID-19 }\end{array}$ & $\begin{array}{l}\text { A donor with } \mathrm{ABO} \\
\text { blood group A } \\
\text { (Rh-positive) in- } \\
\text { compatible with } \\
\text { the patient ABO } \\
\text { blood group B } \\
\text { (Rh-positive) }\end{array}$ & $\begin{array}{l}250 \mathrm{~mL} \text { of } \mathrm{CP} \text { at } 16 \\
\text { days after symptom on- } \\
\text { set for } 2 \text { consecutive } \\
\text { days with mechanical } \\
\text { ventilation and EC- } \\
\mathrm{MO}^{\mathrm{d}} \text {, steroid, hep- } \\
\text { arinization, and antibiot- } \\
\text { ic treatment }\end{array}$ & $\begin{array}{l}\text { The patient showed } \\
\text { clear improvement in } \\
\text { respiratory distress and } \\
\text { fever symptoms for } 3 \\
\text { days after the CP trans- } \\
\text { fusion; discharged } \\
\text { without any detectable } \\
\text { virus or other complica- } \\
\text { tions }\end{array}$ & $\begin{array}{l}\text { No evident } \\
\text { acute adverse } \\
\text { effect }\end{array}$ \\
\hline Jafari et al 2020 [75] & $\begin{array}{l}\text { A woman } 26 \text { years of } \\
\text { age with a twin pregnan- } \\
\text { cy at } 36 \text { weeks and } 1 \\
\text { day gestation with con- } \\
\text { firmed COVID-19 }\end{array}$ & Not reported & $\begin{array}{l}\text { One unit of CP was } \\
\text { transfused on the sixth } \\
\text { day after hospital admis- } \\
\text { sion in addition to } \\
\text { favipiravir and oxy- } \\
\text { tocine }\end{array}$ & $\begin{array}{l}\text { The patient showed } \\
\text { dramatic clinical and } \\
\text { radiologic improve- } \\
\text { ments and was dis- } \\
\text { charged } 2 \text { weeks after } \\
\text { admission with no infec- } \\
\text { tion of the newborns }\end{array}$ & Not reported \\
\hline Jiang et al 2020 [76] & $\begin{array}{l}\text { A kidney transplant fe- } \\
\text { male recipient } 70 \text { years } \\
\text { of age with immunosup- } \\
\text { pression; severe } \\
\text { COVID-19; and a histo- } \\
\text { ry of chronic bronchitis, } \\
\text { hypertension, and hyper- } \\
\text { lipidemia }\end{array}$ & $\begin{array}{l}\text { Collected by } \\
\text { apheresis from a } \\
\text { donor who had re- } \\
\text { covered from } \\
\text { SARS-CoV-2 infec- } \\
\text { tion for >14 days, } \\
\text { with an ELISA } \\
\text { antibody titer } \\
>1: 1000\end{array}$ & $\begin{array}{l}200 \mathrm{~mL} \text { CP was admin- } \\
\text { istered at day } 4 \text { and } 11 \\
\text { after admission in addi- } \\
\text { tion to treatment with } \\
\text { moxifloxacin, } \\
\text { piperacillin, methylpred- } \\
\text { nisolone, tienam, and } \\
\text { fluconazole }\end{array}$ & $\begin{array}{l}\text { The patient's body tem- } \\
\text { perature became normal } \\
\text { and chest } \mathrm{CT}^{\mathrm{f}} \text { was sig- } \\
\text { nificantly better than at } \\
\text { admission, and the pa- } \\
\text { tient was discharged on } \\
\text { day } 30\end{array}$ & Not reported \\
\hline
\end{tabular}




\begin{tabular}{|c|c|c|}
\hline Study design and studies & Population & Details of $\mathrm{CP}^{\mathrm{a}}$ \\
\hline Karataş et al 2020 [77] & $\begin{array}{l}\text { A man } 61 \text { years of age } \\
\text { with a history of AS- } \\
\mathrm{CT}^{\mathrm{g}} \text { for lymphoma with } \\
\text { persistent positive tests } \\
\text { for SARS-CoV-2 RT- } \\
\text { PCR }^{\mathrm{h}} \text { and fever }\end{array}$ & $\begin{array}{l}\text { Obtained using } \\
\text { Trima Accel Auto- } \\
\text { mated Blood Col- } \\
\text { lection System } \\
\text { from a donor satis- } \\
\text { fying universal do- } \\
\text { nation criteria and } \\
\text { recovered from } \\
\text { COVID-19 dis- } \\
\text { ease; ELISA IgG } \\
\text { titer } 13.3\end{array}$ \\
\hline Kong et al 2020 [79] & $\begin{array}{l}\text { A mild COVID-19 } \\
\text { male } 100 \text { years of age } \\
\text { with a } 30 \text {-year record of } \\
\text { hypertension, abdomi- } \\
\text { nal aortic aneurysm, } \\
\text { cerebral infarction, } \\
\text { prostate hyperplasia, } \\
\text { and complete loss of } \\
\text { cognitive function for } \\
\text { the preceding } 3 \text { years }\end{array}$ & $\begin{array}{l}\text { Collected via } \\
\text { plasmapheresis } \\
\text { from a donor who } \\
\text { had recovered from } \\
\text { COVID-19 for } \\
\text { more than } 2 \text { weeks } \\
\text { and had a SARS- } \\
\text { CoV-2 S- } \\
\text { RBD }- \text {-specific IgG } \\
\text { titer >1:640 }\end{array}$ \\
\hline Mira et al 2020 [80] & $\begin{array}{l}\text { A male patient } 39 \text { years } \\
\text { of age with severe } \\
\text { COVID-19 and XLA } \\
\text { receiving monthly im- } \\
\text { munoglobulin replace- } \\
\text { ment therapy }\end{array}$ & $\begin{array}{l}\text { IgG antibodies } \\
\text { against either the } \\
\text { spike or nucleocap- } \\
\text { side viral proteins } \\
\text { with a titer } \geq 1: 320\end{array}$ \\
\hline
\end{tabular}

Soleimani and Soleimani 2020 [82]

Xu et al 2020 [83]

Zhang et al 2020 [84] with severe COVID-19

Not reported
A woman 30 years of age (gravid 3, parity 2) at her 21 and $2 / 7$ weeks gestation with ARDS ${ }^{1}$ caused by SARS-CoV2 infection

A man 65 years of age

A critically ill female 64 years of age with hypertension and diabetes

\begin{tabular}{|c|c|c|}
\hline $\begin{array}{l}\text { Solermani and Soleimani } \\
2020 \text { [82] }\end{array}$ & $\begin{array}{l}\text { age (gravid } 3 \text {, parity } 2 \text { ) } \\
\text { at her } 21 \text { and } 2 / 7 \text { weeks } \\
\text { gestation with } \text { ARDS }^{1} \\
\text { caused by SARS-CoV- } \\
2 \text { infection }\end{array}$ & \\
\hline Xu et al 2020 [83] & $\begin{array}{l}\text { A man } 65 \text { years of age } \\
\text { with severe COVID-19 }\end{array}$ & $\begin{array}{l}\text { Collected from two } \\
\text { convalescent pa- } \\
\text { tients; no details } \\
\text { provided }\end{array}$ \\
\hline Zhang et al 2020 [84] & $\begin{array}{l}\text { A critically ill female } \\
64 \text { years of age with } \\
\text { hypertension and dia- } \\
\text { betes }\end{array}$ & $\begin{array}{l}\text { Collected by } \\
\text { apheresis from a } \\
\text { male } 37 \text { years of } \\
\text { age with blood } \\
\text { type } \mathrm{O} \text { at } 36 \text { days } \\
\text { after symptom on- } \\
\text { set and } 17 \text { days af- } \\
\text { ter discharge; CP } \\
\text { IgG titer }>1: 320 \text { by } \\
\text { ELISA }\end{array}$ \\
\hline
\end{tabular}

Collected from two convalescent patients; no details provided

Collected by apheresis from a male 37 years of age with blood type $\mathrm{O}$ at 36 days after symptom onset and 17 days after discharge; $\mathrm{CP}$ IgG titer $>1: 320$ by ELISA
The patient received $\mathrm{CP}$ twice: $200 \mathrm{ml}$ on the

seventh day of hospital- by a factor of $\sim 18,24 \mathrm{~h}$ ization and $100 \mathrm{ml}$ on after the first transfuthe 11th day of hospital- sion of convalescent ization plasma and then became undetectable after the second, discharged on day 13 of hospitalization

$200 \mathrm{~mL}$, single dose, on day 23 after admission

After $24 \mathrm{~h}$ of infusion, fever ceased without subsequent reappearance and with progressive improvement of asthenia. After $48 \mathrm{~h}$ of infusion, no detectable virus in $\mathrm{qPCR}^{\mathrm{k}}$ from nasopharyngeal exudate

$\mathrm{CP}$ was administered in addition to lopinavir/ritonavir and azithromycin and early methyl prednisolone therapy

$\mathrm{CP}$ was given at a $400-$ $\mathrm{mL}$ dose on day 1 and 2 after admission, and hydroxychloroquine was orally administrated for a week

$200 \mathrm{~mL}$ CP on day 17 of hospitalization while receiving invasive mechanical ventilation
A mild clinical improvement and decrease in inflammatory markers; normal growth of the fetus

On day 11 after $\mathrm{CP}$ transfusion, temperature returned to normal and mechanical ventilation was withdrawn, the positive in throat swab, and CT revealed severe pulmonary lesions

The patient did not re- No adverse quire mechanical venti- event lation 11 days after plasma transfusion and was transferred from ICU to a general ward RNA test remained
No apparent side effects

(n)
Adverse events related to $\mathrm{CP}$ therapy

Not reported sion, his fever resolved hospital on the 78th day of hospitalization; viral
shedding remained positive as demonstrated by RT-PCR

Not reported

Not reported

Case series 


\begin{tabular}{|c|c|c|c|c|c|}
\hline Study design and studies & Population & Details of $\mathrm{CP}^{\mathrm{a}}$ & $\begin{array}{l}\text { Interventions and com- } \\
\text { parisons }\end{array}$ & $\begin{array}{l}\text { Outcomes/main find- } \\
\text { ings }\end{array}$ & $\begin{array}{l}\text { Adverse events } \\
\text { related to } \mathrm{CP} \\
\text { therapy }\end{array}$ \\
\hline Ahn et al 2020 [85] & $\begin{array}{l}\text { A previously healthy } \\
\text { man } 71 \text { years of age } \\
\text { and a woman } 67 \text { years } \\
\text { of age with a medical } \\
\text { history of hypertension, } \\
\text { both diagnosed with se- } \\
\text { vere COVID-19 }\end{array}$ & $\begin{array}{l}\text { Obtained with } \\
\text { Spectra Optia } \\
\text { apheresis system } \\
\text { from a male donor } \\
\text { in his } 20 \text { s who had } \\
\text { recovered from } \\
\text { COVID-19 for } 21 \\
\text { and } 18 \text { days, respec- } \\
\text { tively, and met the } \\
\text { blood donor eligi- } \\
\text { bility criteria for } \\
\text { plasma donation. } \\
\text { ELISA optical } \\
\text { density ratio for } \\
\text { anti-SARS-CoV-2 } \\
\text { IgG was } 0.586 \text { and } \\
0.532 \text { (cutoff value } \\
0.22 \text { ) }\end{array}$ & $\begin{array}{l}\text { A total } 500 \mathrm{~mL} \text { of } \mathrm{CP} \\
\text { was divided into two } \\
\text { doses and given over } 1 \\
\text { hour for each dose at } \\
\text { 12-hour intervals after } \\
22 \text { days from the onset } \\
\text { of symptoms in case } 1 \\
\text { and } 7 \text { days in case } 2\end{array}$ & $\begin{array}{l}\text { SARS-CoV-2 became } \\
\text { negative in both cases: } \\
\text { case } 1 \text { underwent a tra- } \\
\text { cheostomy and current- } \\
\text { ly was successfully } \\
\text { weaned from the me- } \\
\text { chanical ventilator; case } \\
2 \text { was successfully extu- } \\
\text { bated and discharged } \\
\text { from the hospital on } \\
\text { day } 24\end{array}$ & $\begin{array}{l}\text { No adverse reac- } \\
\text { tion occurred } \\
\text { after the admin- } \\
\text { istration of } \mathrm{CP}\end{array}$ \\
\hline Abdullah et al 2020 [86] & $\begin{array}{l}\text { A male } 46 \text { years of age } \\
\text { and a male } 56 \text { years of } \\
\text { age, both with hyperten- } \\
\text { sion and severe } \\
\text { COVID-19 }\end{array}$ & $\begin{array}{l}\text { Collected from a } \\
\text { recovered moder- } \\
\text { ate COVID-19 pa- } \\
\text { tient after perform- } \\
\text { ing necessary inves- } \\
\text { tigations for donor } \\
\text { plasma } \\
\text { (hemoglobin level } \\
\text { and viral screen) } \\
\text { but not antibody } \\
\text { tests }\end{array}$ & $\begin{array}{l}\text { Deteriorated despite } \\
\text { supportive care and an- } \\
\text { tiviral therapy: } 200 \mathrm{~mL} \\
\text { of CP at day } 3 \text { of hospi- } \\
\text { talization (day } 7 \text { after } \\
\text { symptom onset) in case } \\
1 \text {; day } 10 \text { of hospitaliza- } \\
\text { tion (day } 13 \text { after } \\
\text { symptom onset) in case } \\
2\end{array}$ & $\begin{array}{l}\text { Improve clinically } 4 \\
\text { days and } 70 \mathrm{~h} \text { after } \mathrm{CP} \text {, } \\
\text { discharged from the } \\
\text { hospital } 16 \text { and } 21 \text { days } \\
\text { after admission with } \\
\text { three consecutive nega- } \\
\text { tive RT-PCR tests each } \\
\text { with at least } 24 \mathrm{~h} \text { apart }\end{array}$ & Not reported \\
\hline Bradfute et al 2020 [87] & $\begin{array}{l}12 \text { hospitalized } \\
\text { COVID- } 19 \text { patients ( } 8 \\
\text { males and } 4 \text { females) } \\
\text { with a median age of } 52 \\
\text { (range } 39-91 \text { ) years, } 9 \\
\text { obese patients, } 10 \text { pa- } \\
\text { tients in the ICU, and } 2 \\
\text { on the general ward }\end{array}$ & $\begin{array}{l}\text { Collected by } \\
\text { apheresis from } \\
\text { donors } \geq 28 \text { days } \\
\text { after positive PCR } \\
\text { test, with complete } \\
\text { recovery from } \\
\text { COVID-19 and a } \\
\text { median of neutraliz- } \\
\text { ing antibody titer } \\
\text { of } 1: 40 \text { (range, un- } \\
\text { detectable to } \\
1: 160 \text { ) }\end{array}$ & $\begin{array}{l}\text { Patients received one } \\
\text { unit ( } 200 \mathrm{~mL}) \mathrm{CP} \text { at a } \\
\text { median of } 8.5 \text { (range 6- } \\
\text { 16) days after the onset } \\
\text { of symptoms and a me- } \\
\text { dian } 3.5 \text { (range } 1-10 \text { ) } \\
\text { days after hospitaliza- } \\
\text { tion }\end{array}$ & $\begin{array}{l}\text { Temporal increases in } \\
\text { neutralizing antibody } \\
\text { titers and IgG/IgM lev- } \\
\text { els, gradual decreases } \\
\text { in viral loads, with two } \\
\text { deaths within } 14 \text { days } \\
\text { after CP transfusion }\end{array}$ & $\begin{array}{l}\text { No serious ad- } \\
\text { verse events }\end{array}$ \\
\hline Diorio et al 2020 [88] & $\begin{array}{l}\text { Four critically ill chil- } \\
\text { dren with COVID-19; } \\
\text { 14-18 years; female; } \\
\text { varied antibody titer } \\
\text { levels pretransfusion }\end{array}$ & $\begin{array}{l}\text { Collected from } \\
\text { donors proven pos- } \\
\text { itive for SARS - } \\
\text { CoV - } 2 \text { by a labo- } \\
\text { ratory test; and ei- } \\
\text { ther } \geq 14 \text { days from } \\
\text { symptom resolu- } \\
\text { tion with a repeat } \\
\text { negative test for } \\
\text { SARS - CoV - } 2 \\
\text { or } \geq 28 \text { days from } \\
\text { symptom resolu- } \\
\text { tion without the re- } \\
\text { peat test. RBD- } \\
\text { specific IgG titer } \\
<1: 160 \text { to }>1: 6000\end{array}$ & $\begin{array}{l}200-220 \mathrm{~mL} \text { of } \mathrm{CP} \text { at } 7- \\
14 \text { days after symptom } \\
\text { onset }\end{array}$ & $\begin{array}{l}1 \text { died; } 2 \text { showed no } \\
\text { clinical improvement; } \\
1 \text { recovered }\end{array}$ & $\begin{array}{l}\text { No emergent } \\
\text { adverse events } \\
\text { related to CP in- } \\
\text { fusion }\end{array}$ \\
\hline Enzmann et al 2020 [89] & $\begin{array}{l}16 \text { critically ill COVID- } \\
19 \text { patients with most } \\
\text { (12 patients) underlying } \\
\text { cardiovascular disease }\end{array}$ & Not reported & Not reported & $\begin{array}{l}\text { In-hospital mortality } \\
\text { rate was } 31 \% \text { and medi- } \\
\text { an length of hospital } \\
\text { stay was } 19(8-36) \text { days }\end{array}$ & $\begin{array}{l}\text { No apparent ad- } \\
\text { verse effects }\end{array}$ \\
\hline
\end{tabular}




\begin{tabular}{|c|c|c|c|c|c|}
\hline Study design and studies & Population & Details of $\mathrm{CP}^{\mathrm{a}}$ & $\begin{array}{l}\text { Interventions and com- } \\
\text { parisons }\end{array}$ & $\begin{array}{l}\text { Outcomes/main find- } \\
\text { ings }\end{array}$ & $\begin{array}{l}\text { Adverse events } \\
\text { related to } \mathrm{CP} \\
\text { therapy }\end{array}$ \\
\hline Erkurt et al 2020 [90] & $\begin{array}{l}26 \text { ( } 8 \text { females and } 18 \\
\text { males) severe COVID- } \\
19 \text { patients (mean age } \\
67.4, \text { SD } 15.5 \text { years) }\end{array}$ & $\begin{array}{l}\text { Collected via } \\
\text { apheresis } \geq 14 \text { days } \\
\text { after complete re- } \\
\text { covery from the el- } \\
\text { igible blood donors } \\
\text { who had mild or } \\
\text { moderate COVID- } \\
19 \text { with positive } \\
\text { antibodies }\end{array}$ & $\begin{array}{l}200 \mathrm{~mL} \text { of } \mathrm{CP} \text { was ad- } \\
\text { ministered at a mean } \\
13.87 \text { (SD 6.5) days af- } \\
\text { ter admission in addi- } \\
\text { tion to supportive treat- } \\
\text { ment, hydroxychloro- } \\
\text { quine, azithromycin, } \\
\text { and favipiravir }\end{array}$ & $\begin{array}{l}\text { The patients who did } \\
\text { not need mechanical } \\
\text { ventilation improved } \\
\text { with CP treatment, } \\
\text { while } 6 \text { of } 17 \text { patients } \\
\text { on mechanical ventila- } \\
\text { tion were dead }\end{array}$ & $\begin{array}{l}\text { No severe ad- } \\
\text { verse reactions }\end{array}$ \\
\hline Fung et al 2020 [56] & $\begin{array}{l}4 \text { immune-suppressed } \\
\text { patients (males: two } \\
\text { were aged } 42 \text { years and } \\
\text { one was aged } 62 \text { years; } \\
\text { female: one aged } 65 \\
\text { years) with or at risk of } \\
\text { progression to severe or } \\
\text { life-threatening } \\
\text { COVID-19 }\end{array}$ & $\begin{array}{l}\text { Collected per } \\
\text { FDA }^{\mathrm{m}} \text { guidance } \\
\text { from donors with } \\
\text { confirmed } \\
\text { COVID-19 and } \\
\text { resolution of } \\
\text { symptoms within } \\
\text { 14-28 days and a } \\
\text { negative PCR test } \\
\text { or }>28 \text { days with- } \\
\text { out a PCR test; } \\
\text { ELISA an- } \\
\text { ti-SARS-CoV-2 } \\
\text { spike protein IgG } \\
\text { titer }>1: 400\end{array}$ & $\begin{array}{l}\text { Approximately } 200 \mathrm{~mL} \\
\text { of CP was transfused at } \\
\text { 4-27 days following } \\
\text { symptom onset }\end{array}$ & $\begin{array}{l}\text { All patients were clini- } \\
\text { cally improved, with } 2 \\
\text { discharged home and } \\
\text { fully recovered, and } 2 \\
\text { discharged to skilled } \\
\text { nursing facilities }\end{array}$ & $\begin{array}{l}\text { No adverse reac- } \\
\text { tions }\end{array}$ \\
\hline Gemici et al 2020 [91] & $\begin{array}{l}40 \text { consecutive patients } \\
\text { (median age } 57.5 \text { years } \\
\text { and } 72.5 \% \text { male) with } \\
\text { severe COVID-19 }\end{array}$ & $\begin{array}{l}\text { Collected from eli- } \\
\text { gible blood donors } \\
\text { recovered from } \\
\text { COVID-19 with } \\
\text { negative laboratory } \\
\text { results and symp- } \\
\text { tom free for } \geq 14 \\
\text { days }\end{array}$ & $\begin{array}{l}\text { Patients received a me- } \\
\text { dian of } 2 \text { (range } 1-3 \text { ) } \\
\text { units of } \mathrm{CP} \text { at median } \\
\text { time of } 5 \text { days from the } \\
\text { diagnosis in addition to } \\
\text { antiviral therapy }\end{array}$ & $\begin{array}{l}90 \% \text { of patients who } \\
\text { received CP outside } \\
\text { ICU totally recovered } \\
\text { at a median of } 9 \text { days } \\
\text { after the transfusion, } \\
\text { and half of the patients } \\
\text { treated in ICU were free } \\
\text { of mechanical ventila- } \\
\text { tion }\end{array}$ & $\begin{array}{l}\text { No TRALI }{ }^{\mathrm{n}} \text { or } \\
\text { severe allergic } \\
\text { reactions }\end{array}$ \\
\hline Hartman et al 2020 [63] & $\begin{array}{l}16 \text { ( } 7 \text { female) severe } \\
\text { and } 15 \text { ( } 3 \text { female) life- } \\
\text { threatened patients }\end{array}$ & $\begin{array}{l}\text { Collected from a } \\
\text { local donor recruit- } \\
\text { ment and referral } \\
\text { program }\end{array}$ & $\begin{array}{l}\text { Dose and timing not re- } \\
\text { ported }\end{array}$ & $\begin{array}{l}\text { Respiratory support re- } \\
\text { quirements began on or } \\
\text { about day } 7 \text { following } \\
\mathrm{CP} \text { transfusion, especial- } \\
\text { ly in the severe patients }\end{array}$ & Not reported \\
\hline Ibrahim et al 2020 [92] & $\begin{array}{l}38 \text { hospitalized, severe- } \\
\text { ly }(n=16) \text { or critically } \\
\text { ill patients ( } n=22) \text { with } \\
\text { confirmed COVID-19 } \\
\text { (mean age } 63, \text { SD } 12 \\
\text { years; } 18 \text { female); } \\
31.5 \% \text { had three or } \\
\text { more comorbidities, } \\
\text { with } 68 \% \text { having hyper- } \\
\text { tension and } 47 \% \text { having } \\
\text { diabetes }\end{array}$ & $\begin{array}{l}\text { Collected by } \\
\text { apheresis from } \\
\text { adults who were } \\
\text { confirmed positive } \\
\text { and had recovered } \\
\text { from SARS-CoV- } \\
2 \text { with negative } \\
\text { PCT test for the } \\
\text { virus and had total } \\
\text { anti-SARS-CoV-2 } \\
\text { titer }>1: 320\end{array}$ & $\begin{array}{l}\text { ABO-compatible CP } \\
\text { was given in two con- } \\
\text { secutive } 200-\mathrm{mL} \text { infu- } \\
\text { sions (mean } 18.7, \mathrm{SD} \\
\text { 9.0) days following } \\
\text { symptom onset. Anoth- } \\
\text { er unit of CP was given } \\
\text { to those with unde- } \\
\text { tectable anti-SARS- } \\
\text { CoV-2 antibodies. }\end{array}$ & $\begin{array}{l}24(63 \%) \text { recovered and } \\
\text { were discharged from } \\
\text { the hospital, and } 14 \\
(37 \%) \text { died. The sur- } \\
\text { vival patients received } \\
\text { CP earlier in their } \\
\text { course of disease (mean } \\
15.3, \text { SD } 6.9 \text { days) and } \\
\text { hospital stay (mean } 8.4 \text {, } \\
\text { SD } 6.8 \text { days) compared } \\
\text { to those who died with } \\
\text { mean durations of } 24.5 \\
\text { (SD 9.6) days and } 16.6 \\
\text { (SD 9.5) days, respec- } \\
\text { tively. }\end{array}$ & $\begin{array}{l}\text { No adverse ef- } \\
\text { fects except for } \\
\text { a transient } \\
\text { transfusion reac- } \\
\text { tion (fever and } \\
\text { hematuria) } \\
\text { within } 2 \text { h of } \\
\mathrm{CP} \text { infusion in } \\
1 \text { patient }\end{array}$ \\
\hline
\end{tabular}




\begin{tabular}{|c|c|c|c|c|c|}
\hline Study design and studies & Population & Details of $\mathrm{CP}^{\mathrm{a}}$ & $\begin{array}{l}\text { Interventions and com- } \\
\text { parisons }\end{array}$ & $\begin{array}{l}\text { Outcomes/main find- } \\
\text { ings }\end{array}$ & $\begin{array}{l}\text { Adverse events } \\
\text { related to } \mathrm{CP} \\
\text { therapy }\end{array}$ \\
\hline Bobek et al 2020 [93] & $\begin{array}{l}2 \text { critically ill Hungari- } \\
\text { an patients (males } 59 \\
\text { and } 72 \text { years of age) } \\
\text { with COVID-19, hyper- } \\
\text { tension, and cardiovas- } \\
\text { cular disease }\end{array}$ & $\begin{array}{l}\text { Collected by } \\
\text { plasmapheresis } \\
\text { from recovered } \\
\text { COVID-19 pa- } \\
\text { tients who had } \\
\text { been asymptomatic } \\
\text { for at least } 2 \\
\text { weeks, negative } \\
\text { PCR tests, and } \\
\text { IgG-type antibody } \\
\text { detectable by } \\
\text { ELISA }\end{array}$ & $\begin{array}{l}3 \times 200 \mathrm{~mL} \text { of CP with } \\
\text { the first dose adminis- } \\
\text { tered on the fourth day } \\
\text { of the patient's ICU } \\
\text { mechanical ventilation }\end{array}$ & $\begin{array}{l}\text { Both showed improved } \\
\text { oxygenation and inflam- } \\
\text { matory decreased } \\
\text { markers, and were } \\
\text { weaned from mechani- } \\
\text { cal ventilation within } 2 \\
\text { weeks }\end{array}$ & $\begin{array}{l}\text { No severe ad- } \\
\text { verse effects }\end{array}$ \\
\hline Jin et al 2020 [94] & $\begin{array}{l}3 \text { patients (males } 10, \\
24, \text { and } 40 \text { years of age) } \\
\text { with XLA, hospitalized } \\
\text { for COVID-19 }\end{array}$ & $\begin{array}{l}\text { CP containing anti- } \\
\text { spike protein titer } \\
1 \geq: 320\end{array}$ & $\begin{array}{l}\text { Two units of } 200 \mathrm{~mL} \\
\text { ABO-compatible CP } \\
\text { were given on days } 16 \text {, } \\
22 \text {, or } 44 \text { of illness } \\
\text { when there was mini- } \\
\text { mal improvement on } \\
\text { other therapies }\end{array}$ & $\begin{array}{l}\text { Various clinical and } \\
\text { laboratory improve- } \\
\text { ments including increas- } \\
\text { es in antibody titers; } \\
\text { discharged within days } \\
\text { after CP transfusion }\end{array}$ & Not reported \\
\hline Joyner et al 2020 [95] & $\begin{array}{l}5000 \text { hospitalized adults } \\
\text { (median age of 62) with } \\
81 \% \text { having severe or } \\
\text { life-threatening } \\
\text { COVID-19 and } 66 \% \\
\text { admitted to ICU }\end{array}$ & $\begin{array}{l}\text { ABO-compatible } \\
\mathrm{CP}\end{array}$ & $\mathrm{CP}$ dose of $200-500 \mathrm{~mL}$ & $\begin{array}{l}\text { The incidence of SAEs } \\
\text { was less than } 1 \% \text {, and } \\
\text { the mortality rate at the } \\
\text { seventh day after CP } \\
\text { transfusion was } 14.9 \%\end{array}$ & $\begin{array}{l}\text { Of } 36 \text { SAEs, } 7 \\
\text { and } 11 \text { incidents } \\
\text { of TACO }{ }^{p} \text { and } \\
\text { TRALI, respec- } \\
\text { tively, were } \\
\text { judged as relat- } \\
\text { ed to CP transfu- } \\
\text { sion }\end{array}$ \\
\hline Joyner et al 2020 [96] & $\begin{array}{l}20,000 \text { hospitalized } \\
\text { adults (aged } 20-80 \\
\text { years) with severe or } \\
\text { life-threatening } \\
\text { COVID-19 }\end{array}$ & $\begin{array}{l}\text { ABO-compatible } \\
\mathrm{CP} \text { with no mini- } \\
\text { mum neutralizing } \\
\text { antibody titer level } \\
\text { donated by recent- } \\
\text { ly recovered } \\
\text { COVID-19 sur- } \\
\text { vivors }\end{array}$ & $\mathrm{CP}$ dose of $200-500 \mathrm{~mL}$ & $\begin{array}{l}141 \text { SAEs classified as } \\
\text { transfusion reactions } \\
\text { were reported ( }<1 \% \text { of } \\
\text { all transfusions); } 38 \\
\text { thromboembolic or } \\
\text { thrombotic events and } \\
\text { cardiac events were re- } \\
\text { lated to the transfusion. } \\
\text { The mortality rate at the } \\
\text { seventh day after trans- } \\
\text { fusion was } 13.0 \% \text {. }\end{array}$ & $\begin{array}{l}\text { Of } 141 \text { SAEs, } \\
\text { there were } 36 \\
\text { reports of } \\
\text { TACO, } 21 \text { re- } \\
\text { ports of TRALI, } \\
\text { and } 21 \text { reports } \\
\text { of severe aller- } \\
\text { gic transfusion } \\
\text { reaction }\end{array}$ \\
\hline Joyner et al 2020 [97] & $\begin{array}{l}35,322 \text { hospitalized pa- } \\
\text { tients with (or at risk } \\
\text { of) severe or life- } \\
\text { threatening acute } \\
\text { COVID-19 and a di- } \\
\text { verse representation of } \\
\text { gender, age, weight sta- } \\
\text { tus, race, and ethnicity }\end{array}$ & $\begin{array}{l}\text { Collected from re- } \\
\text { cently recovered } \\
\text { COVID-19 sur- } \\
\text { vivors without } \\
\text { symptoms for } \geq 14 \\
\text { days, and the anti- } \\
\text { body levels in the } \\
\text { units collected } \\
\text { were unknown at } \\
\text { the time. }\end{array}$ & $\begin{array}{l}\text { All patients were treat- } \\
\text { ed with at least one unit } \\
(\sim 200 \mathrm{~mL}) \text { of } \mathrm{CP} \text { with } \\
\text { the option to administer } \\
\text { additional doses if clini- } \\
\text { cally justified in addi- } \\
\text { tion to adjunctive } \\
\text { COVID- } 19 \text { medications }\end{array}$ & $\begin{array}{l}\text { A gradient of } 7 \text { - and } \\
\text { 30-day mortality associ- } \\
\text { ated with higher IgG } \\
\text { levels in CP and early } \\
\text { CP transfusion within } 3 \\
\text { days of COVID-19 diag- } \\
\text { nosis }\end{array}$ & $\begin{array}{l}\text { Reported in } \\
\text { Joyner et al } \\
2020[96]\end{array}$ \\
\hline Liu et al 2020 [117] & $\begin{array}{l}3 \text { critically ill male pa- } \\
\text { tients with COVID - } 19 \\
(42,56, \text { and } 58 \text { years of } \\
\text { age; two healthy; one } \\
\text { with hypertension) }\end{array}$ & $\begin{array}{l}\text { Collected from } \\
\text { COVID-19 sur- } \\
\text { vivors who had } \\
\text { fully recovered and } \\
\text { tested negative for } \\
\text { the virus and a to- } \\
\text { tal anti-SARS- } \\
\text { CoV - } 2 \text { IgG titer } \\
\text { of } 160\end{array}$ & $\begin{array}{l}\text { Patients were transfused } \\
\text { with } 200-225 \mathrm{~mL} \mathrm{CP} \\
\text { between } 20 \text { and } 30 \text { days } \\
\text { after disease onset at } \\
\text { the critical illness stage } \\
\text { in addition to standard } \\
\text { care }\end{array}$ & $\begin{array}{l}\text { No therapeutic effect of } \\
\text { CP was observed in any } \\
\text { of the patients }\end{array}$ & Not reported \\
\hline
\end{tabular}




\begin{tabular}{|c|c|c|c|c|c|}
\hline Study design and studies & Population & Details of $\mathrm{CP}^{\mathrm{a}}$ & $\begin{array}{l}\text { Interventions and com- } \\
\text { parisons }\end{array}$ & $\begin{array}{l}\text { Outcomes/main find- } \\
\text { ings }\end{array}$ & $\begin{array}{l}\text { Adverse events } \\
\text { related to } \mathrm{CP} \\
\text { therapy }\end{array}$ \\
\hline Maor et al 2020 [99] & $\begin{array}{l}49 \text { patients (median age } \\
64.0, \text { IQR } 50.5-76.0 \\
\text { years; } 35 \text { males) with } \\
\text { moderate and severe } \\
\text { COVID-19 and comor- } \\
\text { bidities (diabetes and } \\
\text { hypertension) in one- } \\
\text { third of the patients }\end{array}$ & $\begin{array}{l}\text { Collected by } \\
\text { apheresis proce- } \\
\text { dure from recov- } \\
\text { ered COVID-19 } \\
\text { patients eligible for } \\
\text { plasma donation } \\
\text { and >14 days since } \\
\text { the last negative } \\
\text { PCR test; neutraliz- } \\
\text { ing antibody titer } \\
\text { 1:20-1:2560 }\end{array}$ & $\begin{array}{l}\text { The first dose of } \\
200 \mathrm{~mL} \text { CP was trans- } \\
\text { fused at a median of } \\
10.0 \text { (IQR } 4.0-14.0 \text { ) } \\
\text { days after PCR diagno- } \\
\text { sis, followed by a sec- } \\
\text { ond unit of } 200 \mathrm{~mL} \\
24 \text { h later, in addition to } \\
\text { various standard of care }\end{array}$ & $\begin{array}{l}\text { At day } 14 \text { after the first } \\
\text { CP dose, } 24 \text { patients } \\
\text { improved, } 9 \text { died, and } \\
13 \text { were ventilated. } \\
\text { More patients improved } \\
\text { when treated with CP } \\
\text { containing higher anti- } \\
\text { body levels or earlier. }\end{array}$ & $\begin{array}{l}\text { No serious ad- } \\
\text { verse events ex- } \\
\text { cept that one } \\
\text { developed a } \\
\text { rash that re- } \\
\text { sponded to anti- } \\
\text { histamine thera- } \\
\text { py }\end{array}$ \\
\hline Naeem et al 2020 [100] & $\begin{array}{l}3 \text { kidney transplant re- } \\
\text { cipients with COVID - } \\
19 \text { treated with CP (1 } \\
\text { female } 65 \text { years of age } \\
\text { admitted to the general } \\
\text { medicine service and a } \\
\text { female aged } 35 \text { years } \\
\text { and a male } 36 \text { years of } \\
\text { age in the ICU) }\end{array}$ & $\begin{array}{l}\text { Collected from } \\
\text { donors at local and } \\
\text { regional blood cen- } \\
\text { ters }\end{array}$ & $\begin{array}{l}\text { One or two units of CP } \\
\text { were given on day } 2,4 \text {, } \\
\text { or } 7 \text { after hospital admis- } \\
\text { sion, in addition to im- } \\
\text { munosuppressant/ an- } \\
\text { tiviral/antibiotic }\end{array}$ & $\begin{array}{l}\text { All showed clinical im- } \\
\text { provement and were } \\
\text { discharged } 9,16 \text {, and } \\
25 \text { days after hospital } \\
\text { admission with no evi- } \\
\text { dent infectious compli- } \\
\text { cations }\end{array}$ & $\begin{array}{l}1 \text { patient experi- } \\
\text { enced acute } \\
\text { chest pain and } \\
\text { dyspnea but im- } \\
\text { proved over the } \\
\text { following } 12- \\
24 \mathrm{~h} \text {. }\end{array}$ \\
\hline $\begin{array}{l}\text { Olivares-Gazca et al } 2020 \\
\text { [101] }\end{array}$ & $\begin{array}{l}10 \text { male severe } \\
\text { COVID-19 patients } \\
\text { with a median age of } 53 \\
\text { (range 27-72) years and } \\
\text { comorbidities (diabetes, } \\
\text { hypertension) }\end{array}$ & $\begin{array}{l}\text { Obtained by } \\
\text { apheresis from } 5 \\
\text { donors ( } 2 \text { females) } \\
\text { with a median age } \\
\text { of } 35 \text { (range } 24-52 \text { ) } \\
\text { years and two neg- } \\
\text { ative PCR tests in } \\
\text { a } 24 \text {-h interval } 10 \\
\text { days after the reso- } \\
\text { lution of COVID- } \\
19 \text { symptoms }\end{array}$ & $\begin{array}{l}\text { Each patient received } \\
200 \mathrm{~mL} \text { of } \mathrm{ABO}-\mathrm{com}- \\
\text { patible } \mathrm{CP} \text { and other } \\
\text { therapies (eg, steroids } \\
\text { or hydroxychloroquine) }\end{array}$ & $\begin{array}{l}\text { Improvement in overall } \\
\text { respiratory function and } \\
\text { clinical condition over } \\
\text { a period of } 8 \text { days, with } \\
6 \text { discharged and } 2 \text { died }\end{array}$ & No side effects \\
\hline Pal et al 2020 [102] & $\begin{array}{l}17 \text { critically ill patients } \\
\text { (mean age } 56, \text { range } 24- \\
81 \text { years; } 10 \text { males) } \\
\text { with COVID - } 19 \text { and } \\
\text { most patients had multi- } \\
\text { ple medical comorbidi- } \\
\text { ties, including } 6 \text { with } \\
\text { hematological malignan- } \\
\text { cies }\end{array}$ & $\begin{array}{l}\text { Collected from } \\
\text { donors } 18-56 \text { days } \\
\text { following full re- } \\
\text { covery from } \\
\text { COVID-19 with } \\
\text { anti-SARS-CoV-2 } \\
\text { spike protein IgG } \\
\text { titers 1:400-1:6400 } \\
\text { as measured by } \\
\text { ELISA }\end{array}$ & $\begin{array}{l}\text { A single unit of } 200 \mathrm{~mL} \\
\mathrm{CP} \text { was given at an aver- } \\
\text { age time of } 12 \text { (range } \\
4-41 \text { ) days from ill- } \\
\text { ness; } 3 \text { patients re- } \\
\text { ceived two units rough- } \\
\text { ly } 8 \text { days apart in addi- } \\
\text { tion to other COVID- } 19 \\
\text { treatment and } \\
\text { chemotherapy as re- } \\
\text { quired }\end{array}$ & $\begin{array}{l}\text { All patients showed a } \\
\text { decline in oxygen needs } \\
\text { and ventilatory support } \\
\text { with most effects seen } \\
\text { in patients when CP } \\
\text { was administered early } \\
\text { in their disease course }\end{array}$ & $\begin{array}{l}\text { No adverse } \\
\text { events except a } \\
\text { fever during } \\
\text { transfusion in } 1 \\
\text { patient, result- } \\
\text { ing in infusion } \\
\text { of only } 100 \mathrm{~mL}\end{array}$ \\
\hline Rahman et al 2020 [103] & $\begin{array}{l}13 \mathrm{SOT}^{\mathrm{q}} \text { recipients } \\
\text { (median age } 51 \text {, range } \\
20-75 \text { years; } 8 \text { males) } \\
\text { with severe COVID-19 } \\
\text { and comorbidities (eg, } \\
\text { hypertension and dia- } \\
\text { betes) }\end{array}$ & $\begin{array}{l}\text { Collected from eli- } \\
\text { gible blood donors } \\
\text { with anti-SARS- } \\
\mathrm{CoV}-2 \text { spike pro- } \\
\text { tein antibody titers } \\
\geq 1: 320 \text { as mea- } \\
\text { sured by ELISA }\end{array}$ & $\begin{array}{l}\text { All patients received } \\
\text { two ABO-compatible } \\
\text { units of } \mathrm{CP} \text {, for a total } \\
\text { of } 500 \mathrm{~mL} \text {, at a median } \\
\text { time of } 8 \text { days from } \\
\text { symptom onset and ad- } \\
\text { ditional therapies (hy- } \\
\text { droxychloroquine alone } \\
\text { or in combination with } \\
\text { azithromycin, steroids, } \\
\text { anticoagulation, and } \\
\text { immunosuppression) }\end{array}$ & $\begin{array}{l}8 \text { patients had de-esca- } \\
\text { lating oxygenation sup- } \\
\text { port by day } 7 \text { post CP. } \\
9 \text { patients were dis- } \\
\text { charged, } 1 \text { still hospital- } \\
\text { ized, and } 3 \text { patients died } \\
\sim 3 \text { months after the CP } \\
\text { transfusion. }\end{array}$ & $\begin{array}{l}\text { No apparent } \\
\text { transfusion-relat- } \\
\text { ed adverse reac- } \\
\text { tions }\end{array}$ \\
\hline
\end{tabular}




\begin{tabular}{|c|c|c|c|c|c|}
\hline Study design and studies & Population & Details of $\mathrm{CP}^{\mathrm{a}}$ & $\begin{array}{l}\text { Interventions and com- } \\
\text { parisons }\end{array}$ & $\begin{array}{l}\text { Outcomes/main find- } \\
\text { ings }\end{array}$ & $\begin{array}{l}\text { Adverse events } \\
\text { related to } \mathrm{CP} \\
\text { therapy }\end{array}$ \\
\hline Salazar et al 2020 [104] & $\begin{array}{l}25 \text { patients (median age } \\
51 \text { years) with severe or } \\
\text { life-threatening } \\
\text { COVID-19 and one or } \\
\text { more underlying chron- } \\
\text { ic conditions }\end{array}$ & $\begin{array}{l}\text { Obtained from } \\
\text { donors eligible ac- } \\
\text { cording to standard } \\
\text { blood donor crite- } \\
\text { ria, confirmed } \\
\text { SARS-CoV-2 infec- } \\
\text { tion and symptom } \\
\text { free for } 14 \text { days, } \\
\text { and tested negative } \\
\text { for SARS-CoV-2 } \\
\text { by RT-PCR; } \\
\text { ELISA IgG titer } \\
\text { ranged from } 0 \text { to } \\
\text { 1350 }\end{array}$ & $\begin{array}{l}\text { One } 300-\mathrm{mL} \text { dose of } \\
\mathrm{CP} \text { at a median time of } \\
10 \text { days from symptom } \\
\text { onset and concomitant } \\
\text { anti-inflammatory and } \\
\text { antiviral treatments, and } \\
1 \text { patient received a } \\
\text { second dose } 6 \text { days af- } \\
\text { ter the initial transfu- } \\
\text { sion }\end{array}$ & $\begin{array}{l}\text { By day } 14 \text { of CP trans- } \\
\text { fusion, } 19(76 \%) \text { pa- } \\
\text { tients had clinical im- } \\
\text { provement and } 11 \text { were } \\
\text { discharged }\end{array}$ & $\begin{array}{l}\text { No adverse } \\
\text { events within } \\
24 \mathrm{~h} \text { after trans- } \\
\text { fusion. } 1 \text { patient } \\
\text { developed a } \\
\text { morbilliform } \\
\text { rash } 1 \text { day after } \\
\text { transfusion that } \\
\text { lasted for sever- } \\
\text { al days. }\end{array}$ \\
\hline Shen et al 2020 [105] & $\begin{array}{l}5 \text { critically ill patients } \\
\text { (age range } 36-65 \text { years; } \\
2 \text { female) with laborato- } \\
\text { ry-confirmed COVID- } \\
\text { 19, rapid progression, } \\
\text { and continuously high } \\
\text { viral load despite antivi- } \\
\text { ral treatment }\end{array}$ & $\begin{array}{l}\text { Obtained from } 5 \\
\text { patients who recov- } \\
\text { ered from COVID- } \\
\text { 19; anti-SARS- } \\
\text { CoV-2 IgG titer } \\
>1: 1000 \text { as deter- } \\
\text { mined by ELISA } \\
\text { and a neutraliza- } \\
\text { tion titer }>40\end{array}$ & $\begin{array}{l}\text { ABO-compatible CP } \\
\text { was administered at a } \\
\text { dose of } 200-250 \text { twice } \\
\text { ( } 400 \mathrm{~mL} \text { in total) be- } \\
\text { tween } 10 \text { and } 22 \text { days } \\
\text { after admission }\end{array}$ & $\begin{array}{l}\text { Improvement in their } \\
\text { clinical status as indicat- } \\
\text { ed by declined viral } \\
\text { load, body temperature } \\
\text { reduction, improved } \\
\mathrm{Pa}_{\mathrm{O} 2} / \mathrm{F}_{\mathrm{iO} 2} \text {, and chest } \\
\text { imaging }\end{array}$ & Not reported \\
\hline Tremblay et al 2020 [106] & $\begin{array}{l}24 \text { patients with cancer } \\
\text { and severe or life- } \\
\text { threatening COVID-19 } \\
\text { (median age } 69 \text {, range } \\
31-88 \text { years; } 14 \text { males), } \\
\text { some having other co- } \\
\text { morbidities (eg, hyper- } \\
\text { tension in } 15 \text { patients) }\end{array}$ & $\begin{array}{l}\text { Collected via } \\
\text { plasmapheresis, } \\
\text { spike protein-direct- } \\
\text { ed ELISA antibody } \\
\text { titers } \geq 1: 320\end{array}$ & $\begin{array}{l}\text { Two units ( } 250 \mathrm{~mL}) \text { of } \\
\text { ABO-compatible CP } \\
\text { were transfused at } 3 \\
\text { (IQR 2-7) days from } \\
\text { admission in addition to } \\
\text { cancer - directed treat- } \\
\text { ment and COVID- } \\
\text { 19-specific therapies } \\
\text { (hydroxychloroquine, } \\
\text { azithromycin, remde- } \\
\text { sivir, and tocilizumab) }\end{array}$ & $\begin{array}{l}\text { Marked variability in } \\
\text { both the timing and de- } \\
\text { gree of improvement or } \\
\text { worsening of oxygen } \\
\text { requirement; } 13 \text { dis- } \\
\text { charged; } 10 \text { deaths }\end{array}$ & $\begin{array}{l}3 \text { patients expe- } \\
\text { rienced febrile } \\
\text { nonhemolytic } \\
\text { transfusion reac- } \\
\text { tions }\end{array}$ \\
\hline Wang et al 2020 [108] & $\begin{array}{l}5 \text { critically ill COVID- } \\
19 \text { patients (median age } \\
56, \text { IQR 50-62 years) } \\
\text { admitted to ICU with a } \\
\text { persistent (>30 days) } \\
\text { positive nucleic acid } \\
\text { test for SARS-CoV-2 } \\
\text { and underlying chronic } \\
\text { comorbidities, includ- } \\
\text { ing hypertension and } \\
\text { diabetes }\end{array}$ & $\begin{array}{l}\text { Collected from the } \\
\text { recently cured pa- } \\
\text { tients whose anti- } \\
\text { body titers were } \\
\text { above } 1: 640\end{array}$ & $\begin{array}{l}200 \text { mL of cross- } \\
\text { matching CP was trans- } \\
\text { fused over } 15 \text { min initi- } \\
\text { ated at a median of } 37 \\
\text { (IQR } 34-44 \text { ) days from } \\
\text { the onset of symptoms. } \\
\text { In total, } 3 \text { patients re- } \\
\text { ceived } 400 \text { mL and the } \\
\text { other } 2 \text { received } 1200 \\
\text { mL; all received antibi- } \\
\text { otics, antiviral, and an- } \\
\text { ti-inflammatory agents. }\end{array}$ & $\begin{array}{l}\text { Within } 6 \text { days after CP } \\
\text { therapy, all patients be- } \\
\text { came negative for two } \\
\text { consecutive nucleic } \\
\text { acid tests. Additionally, } \\
4-9 \text { days following the } \\
\text { CP, } 3 \text { patients showed } \\
\text { resolution of pulmonary } \\
\text { lesion. } 2 \text { recovered and } \\
3 \text { died. }\end{array}$ & $\begin{array}{l}\text { No adverse reac- } \\
\text { tions }\end{array}$ \\
\hline Wei et al 2020 [107] & $\begin{array}{l}2 \text { COVID- } 19 \text { patients } \\
\text { (males aged } 50 \text { and } 81 \\
\text { years, the latter with } \\
\text { type } 2 \text { diabetes mellitus, } \\
\text { hypertension, and aortic } \\
\text { dissection) with long- } \\
\text { term positive viral infec- } \\
\text { tion }\end{array}$ & Not reported & $\begin{array}{l}\text { One or two } 200-\mathrm{mL} \\
\text { doses of CP were admin- } \\
\text { istered > } 8 \text { weeks after } \\
\text { symptom onset; other } \\
\text { therapeutics: interferon, } \\
\text { arbidol, chloroquine } \\
\text { phosphate, and riton- } \\
\text { avir-boosted danoprevir }\end{array}$ & $\begin{array}{l}\text { Substantial improve- } \\
\text { ment as confirmed by } \\
\text { CT scan and discharged } \\
\text { after three consecutive } \\
\text { negative nucleic acid } \\
\text { tests }\end{array}$ & Not reported \\
\hline
\end{tabular}




\begin{tabular}{|c|c|c|c|c|c|}
\hline Study design and studies & Population & Details of $\mathrm{CP}^{\mathrm{a}}$ & $\begin{array}{l}\text { Interventions and com- } \\
\text { parisons }\end{array}$ & $\begin{array}{l}\text { Outcomes/main find- } \\
\text { ings }\end{array}$ & $\begin{array}{l}\text { Adverse events } \\
\text { related to } \mathrm{CP} \\
\text { therapy }\end{array}$ \\
\hline Wu et al 2020 [109] & $\begin{array}{l}27 \text { adult patients with } \\
\text { prolonged infection for } \\
\text { a median of } 44 \text { (IQR } \\
30-47 \text { ) days between } \\
\text { symptom onset and last } \\
\text { positive test of SARS- } \\
\text { CoV-2 before CP thera- } \\
\text { py (median age } 64, \text { IQR } \\
57-72 \text { years; } 55.5 \% \\
\text { males), some with } \\
\text { chronic diseases }\end{array}$ & $\begin{array}{l}\text { Collected from } \\
\text { donors (without } \\
\text { transfusion-related } \\
\text { infectious diseases } \\
\text { who recovered } \\
\text { from COVID-19) } \\
>3 \text { weeks after } \\
\text { symptom onset and } \\
>10 \text { days after dis- } \\
\text { charge; neutraliz- } \\
\text { ing antibody titer } \\
>1: 160\end{array}$ & $\begin{array}{l}\text { The patients were treat- } \\
\text { ed with a median of } 400 \\
\text { (IQR 200-600) mL CP } \\
\text { at a median of } 45 \text { (IQR } \\
\text { 3549) days after symp- } \\
\text { tom onset and other } \\
\text { therapeutics: antivirals, } \\
\text { antibiotics, corticoid, or } \\
\text { immunoglobulin }\end{array}$ & $\begin{array}{l}\text { The patients showed } \\
\text { pulmonary imaging im- } \\
\text { provement (within } 5-8 \\
\text { days) and viral clear- } \\
\text { ance ( } 18 \text { patients) } 15 \\
\text { days after the CP trans- } \\
\text { fusion, and } 3 \text { died with- } \\
\text { in } 60 \text { days }\end{array}$ & $\begin{array}{l}\text { No transfusion- } \\
\text { related adverse } \\
\text { reactions }\end{array}$ \\
\hline Ye et al 2020 [111] & $\begin{array}{l}6 \text { laboratory - con- } \\
\text { firmed critically } \\
\text { ill COVID - } 19 \text { patients } \\
\text { (mean age } 58, \text { SD } 16.4 \\
\text { years; } 3 \text { male) }\end{array}$ & $\begin{array}{l}\text { Collected from pa- } \\
\text { tients at least } 3 \\
\text { weeks following } \\
\text { disease onset, two } \\
\text { consecutive nega- } \\
\text { tive RT-PCR tests, } \\
\text { and seropositive } \\
\text { for anti-SARS - } \\
\text { CoV-2 IgG and } \\
\text { IgM }\end{array}$ & $\begin{array}{l}\text { One to three doses of } \\
\text { ABO-compatible CP } \\
\text { ( } 200 \text { mL/dose) at 6-31 } \\
\text { days after admission. } \\
\text { Each transfusion was } \\
\text { administered over a } \\
30 \text { - minute period. }\end{array}$ & $\begin{array}{l}\text { A resolution of } \\
\text { ground - glass opacities } \\
\text { and consolidation in } 5 \\
\text { out of } 6 \text { patients and an } \\
\text { elimination of the virus } \\
\text { in } 2 \text { in the following } \\
\text { days of CP therapy }\end{array}$ & $\begin{array}{l}\text { No adverse } \\
\text { events }\end{array}$ \\
\hline Zhang et al 2020 [112] & $\begin{array}{l}4 \text { critically ill patients } \\
\text { infected with SARS- } \\
\text { CoV-2 (age: } 31-73 \\
\text { years; } 2 \text { male) }\end{array}$ & $\begin{array}{l}\text { Prepared from re- } \\
\text { covered patients } \\
\text { without details }\end{array}$ & $\begin{array}{l}\text { One to eight doses of } \\
\mathrm{CP}(200-2400 \mathrm{~mL} \text { in } \\
\text { total) } 11-41 \text { days after } \\
\text { admission in addition to } \\
\text { antiviral therapy }\end{array}$ & $\begin{array}{l}\text { The time from transfu- } \\
\text { sion to negative RT- } \\
\text { PCR test results ranged } \\
\text { from } 3 \text { to } 22 \text { days. } 3 \\
\text { were discharged from } \\
\text { the hospital, and } 1 \text { re- } \\
\text { mained in ICU up to the } \\
\text { time of this writing }\end{array}$ & $\begin{array}{l}\text { No adverse } \\
\text { events }\end{array}$ \\
\hline Zeng et al 2020 [113] & $\begin{array}{l}8 \text { patients ( } 4 \text { males, me- } \\
\text { dian age } 65 \text { years) with } \\
\text { severe or critical } \\
\text { COVID- } 19 ; 5 \text { patients } \\
\text { had coexisting chronic } \\
\text { diseases }\end{array}$ & $\begin{array}{l}\text { Collected from } \\
\text { seven donors (medi- } \\
\text { an age of } 37 \text { years) } \\
\text { who had mild or } \\
\text { moderate COVID- } \\
19 \text { with no comor- } \\
\text { bidities and were at } \\
\text { a median day of } 11 \\
\text { from discharge; } \\
\text { neutralizing anti- } \\
\text { body titer } 1: 255- \\
1: 1576\end{array}$ & $\begin{array}{l}\text { ABO-compatible and } \\
\text { cross-matched CP were } \\
\text { administered at one ( } 3 \\
\text { patients) or two doses } \\
\text { of } 100-200 \mathrm{~mL} \text { of } \mathrm{CP} \\
\text { within } 24 \mathrm{~h} \text { between } 9 \\
\text { and } 34 \text { days following } \\
\text { the onset of symptoms }\end{array}$ & $\begin{array}{l}6 \text { of } 8 \text { patients showed } \\
\text { an improvement in } \\
\text { oxygen support status } \\
\text { within } 5 \text { days from CP } \\
\text { treatment, partial resolu- } \\
\text { tion of pulmonary le- } \\
\text { sions, and decreased vi- } \\
\text { ral load }\end{array}$ & $\begin{array}{l}\text { No adverse } \\
\text { events }\end{array}$ \\
\hline
\end{tabular}




\begin{tabular}{|c|c|c|c|c|c|}
\hline Study design and studies & Population & Details of $\mathrm{CP}^{\mathrm{a}}$ & $\begin{array}{l}\text { Interventions and com- } \\
\text { parisons }\end{array}$ & $\begin{array}{l}\text { Outcomes/main find- } \\
\text { ings }\end{array}$ & $\begin{array}{l}\text { Adverse events } \\
\text { related to } \mathrm{CP} \\
\text { therapy }\end{array}$ \\
\hline $\begin{array}{l}\text { Abolghasemi et al } 2020 \\
{[114]}\end{array}$ & $\begin{array}{l}115 \text { CP treatment group } \\
\text { with an average age of } \\
54.4 \text { years, and } 74 \text { con- } \\
\text { trol group- matched by } \\
\text { age, gender, underlying } \\
\text { diseases (hypertension } \\
\text { and diabetes), and } \\
\text { COVID-19 severity }\end{array}$ & $\begin{array}{l}\text { Selected from clin- } \\
\text { ically and laborato- } \\
\text { ry-confirmed recov- } \\
\text { ered patients of } \\
\text { COVID-19 who } \\
\text { were between the } \\
\text { ages of } 18-60 \text { years } \\
\text { and had no remain- } \\
\text { ing symptoms of } \\
\text { COVID-19 infec- } \\
\text { tion for at least } 14 \\
\text { days; ELISA anti- } \\
\text { body titer cutoff } \\
\text { index }>1.1\end{array}$ & $\begin{array}{l}\text { One unit of } 500 \mathrm{~mL} \\
\text { was infused in }<3 \text { days } \\
\text { of hospital admission } \\
\text { ( } \leq 7 \text { days since illness } \\
\text { onset), followed by an- } \\
\text { other unit if the patient } \\
\text { did not show any im- } \\
\text { provement after } 24 \mathrm{~h}\end{array}$ & $\begin{array}{l}\text { More discharged pa- } \\
\text { tients ( } 98.2 \% \text { vs } 78.7 \\
\%) \text {, shorter hospital stay } \\
\text { ( } 9.54 \text { vs } 12.88 \text { days), } \\
\text { and less requirement for } \\
\text { intubation ( } 7 \% \text { vs } 20 \% \text { ) } \\
\text { in the CP group than } \\
\text { the control group }\end{array}$ & $\begin{array}{l}\text { No adverse ef- } \\
\text { fect }\end{array}$ \\
\hline Duan et al 2020 [115] & $\begin{array}{l}10 \text { severe COVID-19 } \\
\text { patients ( } 6 \text { males and } 4 \\
\text { females) with a median } \\
\text { age of } 52.5 \text { years in } \\
\text { comparison with a his- } \\
\text { toric control group of } \\
10 \text { patients matched by } \\
\text { age, gender, and severi- } \\
\text { ty of the diseases }\end{array}$ & $\begin{array}{l}\text { Collected by } \\
\text { apheresis using a } \\
\text { Baxter CS } 300 \text { cell } \\
\text { separator from } 10 \\
\text { donor patients who } \\
\text { recovered from } \\
\text { COVID-19 at } 3 \\
\text { weeks after illness } \\
\text { and } 4 \text { days after } \\
\text { discharge and two } \\
\text { consecutively nega- } \\
\text { tive results of spu- } \\
\text { tum SARS-CoV-2 } \\
\text { by RT-PCR assay } \\
\text { (1-day sampling } \\
\text { interval) neutraliza- } \\
\text { tion activity of } \\
>1: 640\end{array}$ & $\begin{array}{l}\text { One dose }(200 \mathrm{~mL}) \text { of } \\
\mathrm{CP} \text { at the median time } \\
\text { of } 16 \text { days from onset } \\
\text { of illness in combina- } \\
\text { tion with antiviral, an- } \\
\text { tibiotic or antifungal } \\
\text { treatment, or glucocorti- } \\
\text { coid therapy }\end{array}$ & $\begin{array}{l}\text { Improved clinical } \\
\text { symptoms and paraclin- } \\
\text { ical criteria within } 3 \\
\text { days after CP, varying } \\
\text { degrees of absorption } \\
\text { of lung lesions for all } \\
\text { patients within } 7 \text { days, } \\
\text { as compared to } 3 \\
\text { deaths, } 6 \text { cases in stabi- } \\
\text { lized status, and } 1 \text { case } \\
\text { of improvement in the } \\
\text { control group }(P<.001)\end{array}$ & $\begin{array}{l}\text { No SAEs or } \\
\text { safety events; } 1 \\
\text { patient showed } \\
\text { an evanescent } \\
\text { facial red spot }\end{array}$ \\
\hline Hegerova et al 2020 [116] & $\begin{array}{l}20 \text { patients (median age } \\
60, \text { range } 29-95 \text { years) } \\
\text { with severe or critical } \\
\text { COVID-19 treated with } \\
\text { CP under an expanded } \\
\text { access protocol, as } \\
\text { compared with } 20 \\
\text { matched controls with } \\
\text { regard to age, number } \\
\text { of comorbidities, and } \\
\text { severity of illness }\end{array}$ & $\begin{array}{l}\text { Collected from pa- } \\
\text { tients aged from } 29 \\
\text { to } 79 \text { years who re- } \\
\text { covered from } \\
\text { COVID-19 (symp- } \\
\text { tom free) for }>28 \\
\text { days without hospi- } \\
\text { talization, most } \\
\text { showing an- } \\
\text { ti-SARS-CoV-2 } \\
\text { IgG }\end{array}$ & $\begin{array}{l}\text { One unit of ABO-com- } \\
\text { patible CP was adminis- } \\
\text { tered early at the medi- } \\
\text { an time of } 2 \text { (IQR 1- } \\
\text { 4.3) days from hospital- } \\
\text { ization and additional } \\
\text { therapies (eg, } \\
\text { azithromycin and hy- } \\
\text { droxychloroquine) }\end{array}$ & $\begin{array}{l}\text { Improved laboratory } \\
\text { and respiratory parame- } \\
\text { ters in patients follow- } \\
\text { ing CP infusion, similar } \\
\text { to those in controls but } \\
\text { with lower mortality ( } 2 \\
\text { vs } 6 \text { deaths) }\end{array}$ & $\begin{array}{l}\text { No adverse } \\
\text { events }\end{array}$ \\
\hline Liu et al 2020 [117] & $\begin{array}{l}39 \text { hospitalized patients } \\
\text { (mean age 55, SD } 13 \\
\text { years; } 25 \text { males) with } \\
\text { severe to life-threaten- } \\
\text { ing COVID-19 received } \\
\text { CP transfusion in com- } \\
\text { parison with a cohort of } \\
\text { retrospectively matched } \\
\text { controls }(n=156)\end{array}$ & $\begin{array}{l}\text { Collected by } \\
\text { plasmapheresis } \\
\text { from donors with } \\
\text { antispike antibody } \\
\text { titers } \geq 1: 320 \text { as } \\
\text { measured by } \\
\text { ELISA }\end{array}$ & $\begin{array}{l}\text { Two units ( } 250 \mathrm{~mL} \\
\text { each unit) of ABO-type } \\
\text { matched were infused } \\
\text { over } 1-2 \text { hours at the } \\
\text { median time of } 4 \text { days } \\
\text { after admission in addi- } \\
\text { tion to a variety of inpa- } \\
\text { tient pharmacotherapies }\end{array}$ & $\begin{array}{l}\text { More likely improve- } \\
\text { ments in supplemental } \\
\text { oxygen requirements by } \\
\text { posttransfusion day } 14, \\
\text { improved survival, } \\
\text { compared to control pa- } \\
\text { tients, especially for } \\
\text { nonintubated patients }\end{array}$ & $\begin{array}{l}\text { No significant } \\
\text { transfusion-relat- } \\
\text { ed morbidity or } \\
\text { mortality }\end{array}$ \\
\hline
\end{tabular}




\begin{tabular}{|c|c|c|c|c|c|}
\hline Study design and studies & Population & Details of $\mathrm{CP}^{\mathrm{a}}$ & $\begin{array}{l}\text { Interventions and com- } \\
\text { parisons }\end{array}$ & $\begin{array}{l}\text { Outcomes/main find- } \\
\text { ings }\end{array}$ & $\begin{array}{l}\text { Adverse events } \\
\text { related to } \mathrm{CP} \\
\text { therapy }\end{array}$ \\
\hline Perotti et al 2020 [118] & $\begin{array}{l}46 \text { moderate to severe } \\
\text { COVID-19 patients } \\
\text { (mean age } 63, \text { SD } 12 \\
\text { years), with } 19(41 \%) \\
\text { having two or more co- } \\
\text { morbidities, in compari- } \\
\text { son with a control co- } \\
\text { hort of } 23 \text { consecutive } \\
\text { patients }\end{array}$ & $\begin{array}{l}\text { Collected using a } \\
\text { Trima Accel blood } \\
\text { collection device } \\
\text { from eligible } \\
\text { COVID-19 recov- } \\
\text { ered patients with } \\
2 \text { consecutive nega- } \\
\text { tive tests for } \\
\text { SARS - CoV - } 2, \\
\text { followed by } \\
\text { pathogen reduc- } \\
\text { tion; neutralization } \\
\text { titers } \geq 1: 80\end{array}$ & $\begin{array}{l}24 \text { patients received one } \\
\text { unit of plasma, } 21 \text { re- } \\
\text { ceived two units, and } 1 \\
\text { patient received } 3 \text { units } \\
\text { after having symptoms } \\
\text { for } 2 \text { weeks, with most } \\
\text { having been treated } \\
\text { with antibiotics, hydrox- } \\
\text { ychloroquine, and anti- } \\
\text { coagulants }\end{array}$ & $\begin{array}{l}3 \text { out of } 46 \text { patients } \\
(6.5 \%) \text { died within } 7 \\
\text { days (at } 1,4 \text {, and } 6 \\
\text { days), lower than } 30 \% \\
\text { in the control, and } \\
\text { showed improved respi- } \\
\text { ratory function }\left(\mathrm{PaO}_{2}\right. \\
\left./ \mathrm{FiO}_{2}\right) \text {, chest radio- } \\
\text { gram, laboratory param- } \\
\text { eters }\left(\mathrm{CRP}^{\mathrm{r}} \text {, Ferritin, }\right. \\
\mathrm{LDH}^{\mathrm{s}} \text {, viral load), and } \\
\text { weaning from mechani- } \\
\text { cal ventilation }\end{array}$ & $\begin{array}{l}\text { Five serious ad- } \\
\text { verse events oc- } \\
\text { curred in } 4 \text { pa- } \\
\text { tients. }\end{array}$ \\
\hline Rasheed et al 2020 [119] & $\begin{array}{l}49 \text { early-stage (no more } \\
\text { than } 3 \text { days in ICU) } \\
\text { critically ill COVID-19 } \\
\text { patients randomized to } \\
\text { receive CP or not ( } 21 \\
\text { and } 28 \text { patients, respec- } \\
\text { tively, matched in terms } \\
\text { of age, sex, and comor- } \\
\text { bidities) }\end{array}$ & $\begin{array}{l}\text { Collected from } \\
\text { healthy donors } \\
\text { younger than } 50 \\
\text { years who recov- } \\
\text { ered from moder- } \\
\text { ate COVID-19 and } \\
\text { had a IgG index } \\
\geq 1.25 \text { as measured } \\
\text { by ELISA }\end{array}$ & $\begin{array}{l}400 \mathrm{~mL} \text { of } \mathrm{CP} \text { were } \\
\text { transfused over } 2 \text { hours } \\
\text { in addition to standard } \\
\text { of care in the control } \\
\text { group }\end{array}$ & $\begin{array}{l}\text { CP-treated patients } \\
\text { showed reduced dura- } \\
\text { tion of infection in } \\
\text { about } 4 \text { days, a lower } \\
\text { death rate }(1 / 21 \text { vs } \\
8 / 28) \text {, and higher levels } \\
\text { of SARS-CoV-2 IgG } \\
\text { and IgM } 3 \text { days after } \\
\text { CP transfusion com- } \\
\text { pared to the control } \\
\text { group }\end{array}$ & $\begin{array}{l}\text { No adverse } \\
\text { events except } \\
\text { that } 1 \text { patient } \\
\text { developed mild } \\
\text { skin redness } \\
\text { and itching that } \\
\text { lasted for } 1 \\
\text { hour after CP; } \\
\text { resolved by anti- } \\
\text { histamine injec- } \\
\text { tion }\end{array}$ \\
\hline Roger et al 2020 [120] & $\begin{array}{l}64 \text { patients with symp- } \\
\text { tom onset } \leq 10 \text { days pri- } \\
\text { or to admission and } \\
\text { supplemental oxygen } \\
\text { (but not invasive venti- } \\
\text { lation) within } 48 \text { h of } \\
\text { hospitalization versus a } \\
\text { matched control group } \\
\text { of } 177 \text { patients for all } \\
\text { cause in-hospital mortal- } \\
\text { ity and rate of hospital } \\
\text { discharge at day } 28\end{array}$ & $\begin{array}{l}\text { The SARS-CoV-2 } \\
\text { antibody content in } \\
\text { CP was assessed } \\
\text { retrospectively } \\
\text { with } 13 \% \text { of the } \\
\text { units below the } \\
\text { cutoff for a posi- } \\
\text { tive antibody index }\end{array}$ & $\begin{array}{l}3 \text { of } 64 \text { patients re- } \\
\text { ceived one and the re- } \\
\text { mainder received two } \\
\text { units of CP at a median } \\
\text { of } 7 \text { (IQR 5-9) days af- } \\
\text { ter symptom onset }\end{array}$ & $\begin{array}{l}\text { No significant differ- } \\
\text { ence in the risk of in- } \\
\text { hospital mortality or } \\
\text { overall rate of hospital } \\
\text { discharge between the } \\
\text { two groups, except for } \\
\text { a significantly increased } \\
\text { hospital discharge rate } \\
\text { among patients } 65 \text { years } \\
\text { or older }\end{array}$ & $\begin{array}{l}2 \text { patients had } \\
\text { TRALI reac- } \\
\text { tions associated } \\
\text { with the first } \\
\text { unit of CP, and } \\
1 \text { had TACO } \\
\text { approximately } \\
3 \text { h after transfu- } \\
\text { sion of the sec- } \\
\text { ond unit of CP }\end{array}$ \\
\hline Salazar et al 2020 [121] & $\begin{array}{l}136 \text { severe or life- } \\
\text { threatening COVID-19 } \\
\text { patients treated with CP } \\
\text { versus } 215 \text { propensity } \\
\text { score-matched patients } \\
\text { to assess the efficacy of } \\
\text { CP transfusion com- } \\
\text { pared to standard of } \\
\text { care }\end{array}$ & $\begin{array}{l}\text { Collected from } \\
\text { donors who had } \\
\text { been asymptomatic } \\
\text { for more than } 14 \\
\text { days and had nega- } \\
\text { tive SARS-CoV-2 } \\
\text { RT-PCR tests at } \\
\text { the time of plasma- } \\
\text { pheresis; antispike } \\
\text { IgG antibody titers } \\
\geq 1: 1350 \text { as mea- } \\
\text { sured by ELISA }\end{array}$ & $\begin{array}{l}\text { The majority of patients } \\
\text { received one and some } \\
\text { patients reviewed two } \\
\text { units of CP due to } \\
\text { worsening COVID-19 } \\
\text { conditions }\end{array}$ & $\begin{array}{l}\text { Patients treated by CP } \\
\text { with IgG titer } \geq 1: 1350 \\
\text { within } 72 \text { h of hospital } \\
\text { admission had de- } \\
\text { creased mortality within } \\
28 \text { days }\end{array}$ & $\begin{array}{l}\text { Reported in } \\
\text { Joyner et al } \\
2020[95]\end{array}$ \\
\hline
\end{tabular}




\begin{tabular}{|c|c|c|c|c|c|}
\hline Study design and studies & Population & Details of $\mathrm{CP}^{\mathrm{a}}$ & $\begin{array}{l}\text { Interventions and com- } \\
\text { parisons }\end{array}$ & $\begin{array}{l}\text { Outcomes/main find- } \\
\text { ings }\end{array}$ & $\begin{array}{l}\text { Adverse events } \\
\text { related to } \mathrm{CP} \\
\text { therapy }\end{array}$ \\
\hline Xia et al 2020 [122] & $\begin{array}{l}1568 \text { severe or critical } \\
\text { COVID- } 19 \text { patients, } \\
\text { most with comorbidi- } \\
\text { ties, among whom } 1430 \\
\text { patients (median age of } \\
63 \text { years; } 50 \% \text { male) } \\
\text { only received standard } \\
\text { treatment and } 138 \text { pa- } \\
\text { tients (median age of } 65 \\
\text { years; } 56 \% \text { male) also } \\
\text { received ABO-compati- } \\
\text { ble CP }\end{array}$ & Not reported & $\begin{array}{l}200-1200 \mathrm{~mL} \text { of } \mathrm{CP} \\
\text { were transfused at a } \\
\text { median of } 45 \text { days of } \\
\text { symptom onset ( } 1 \text { week } \\
\text { to } \geq 8 \text { weeks from } \\
\text { symptom onset to CP } \\
\text { therapy) }\end{array}$ & $\begin{array}{l}\text { Compared to that in the } \\
\text { standard treatment } \\
\text { group, there was a re- } \\
\text { duced mortality rate } \\
(2.2 \% \text { vs } 4.1 \%) \text {, lower } \\
\text { admission to ICU ( } 2.4 \% \\
\text { vs } 5.1 \%) \text {, and improved } \\
\text { respiratory symptoms } \\
\text { of severe patients as } \\
\text { evaluated by SCSS }\end{array}$ & $\begin{array}{l}\text { No significant } \\
\text { differences in } \\
\text { cardiac, liver, } \\
\text { and renal func- } \\
\text { tions before and } \\
\text { after CP thera- } \\
\text { py, except for a } \\
\text { decrease in total } \\
\text { bilirubin and } 3 \\
\text { patients with } \\
\text { minor allergic } \\
\text { reactions (pruri- } \\
\text { tus or erythema) } \\
\text { during the } \\
\text { transfusion }\end{array}$ \\
\hline Xiao et al 2020 [123] & $\begin{array}{l}18 \text { patients with severe } \\
\text { and critical COVID-19 } \\
\text { divided into two groups } \\
\text { with no significant dif- } \\
\text { ferences in age, gender, } \\
\text { and basic clinical data: } \\
\text { one with CP transfusion } \\
\text { ( } n=6) \text { and the other } \\
\text { without CP transfusion } \\
(n=12)\end{array}$ & $\begin{array}{l}\text { Collected from } \\
\text { donors between } \\
\text { age 18-55 years } \\
\text { who had fully re- } \\
\text { covered from } \\
\text { COVID-19 without } \\
\text { symptoms for } 2 \\
\text { weeks and } \geq 4 \\
\text { weeks from symp- } \\
\text { tom onset; an- } \\
\text { ti-SARS-CoV-2 } \\
\text { IgG titers > 1:160 }\end{array}$ & $\begin{array}{l}200 \sim 500 \mathrm{~mL}(4 \sim 5 \\
\mathrm{mL} / \mathrm{kg} \text { body weight) of } \\
\text { CP were transfused }\end{array}$ & $\begin{array}{l}\text { No difference between } \\
\text { the two groups of pa- } \\
\text { tients in terms of venti- } \\
\text { lator and ECMO wean- } \\
\text { ing time, time for viral } \\
\text { clearance, and hospital- } \\
\text { ization }\end{array}$ & Not reported \\
\hline Zeng et al 2020 [124] & $\begin{array}{l}21 \text { critically ill patients } \\
\text { with COVID-19 and } \\
\text { respiratory failure: } 6 \\
\text { patients (median age of } \\
61.5 \text { years; } 5 \text { males) in } \\
\text { the CP group versus } 15 \\
\text { patients (median age of } \\
73 \text { years; } 11 \text { males) in } \\
\text { a control group with no } \\
\text { significant differences } \\
\text { in demographic and } \\
\text { clinical features }\end{array}$ & $\begin{array}{l}200-400 \mathrm{~mL} \text { ob- } \\
\text { tained from each } \\
\text { young adult individ- } \\
\text { ual who had recov- } \\
\text { ered from COVID- } \\
19 \text { for } 1-2 \text { weeks } \\
\text { and was negative } \\
\text { for SARS-CoV-2 } \\
\text { RNA and IgM test- } \\
\text { ing, and positive } \\
\text { for IgG testing be- } \\
\text { fore donation }\end{array}$ & $\begin{array}{l}\text { A median volume of } \\
300 \mathrm{~mL} \text { CP was trans- } \\
\text { fused at a median of } \\
21.5 \text { days after viral } \\
\text { shedding was first de- } \\
\text { tected }\end{array}$ & $\begin{array}{l}\text { All CP-treated patients } \\
\text { tested negative for } \\
\text { SARS-CoV-2 RNA } \\
\text { within } 3 \text { days after infu- } \\
\text { sion versus } 26.7 \% \text { in } \\
\text { the control group, but } 5 \\
\text { patients eventually died } \\
\text { with a longer survival } \\
\text { period, suggesting } \\
\text { treatment should be ini- } \\
\text { tiated earlier }\end{array}$ & $\begin{array}{l}\text { No immediate } \\
\text { or noticeable } \\
\text { adverse effects }\end{array}$ \\
\hline \multicolumn{6}{|l|}{$\mathbf{R C T}^{\mathbf{u}}$} \\
\hline Gharbharan et al 2020 [125] & $\begin{array}{l}86 \text { hospitalized patients } \\
\text { (median age of } 63 \\
\text { years; } 72 \% \text { male) ran- } \\
\text { domized at } 1: 1 \text { for stan- } \\
\text { dard of care thera- } \\
\text { py with and without CP }\end{array}$ & $\begin{array}{l}\text { Collected from } \\
\text { donors confirmed } \\
\text { with an RT-PCR } \\
\text { SARS-CoV-2 infec- } \\
\text { tion and were } \\
\text { asymptomatic for } \\
\text { at least } 14 \text { days; } \\
\text { neutralizing anti- } \\
\text { bodies titer } \geq 1: 80 \\
\text { determined by a } \\
\text { SARS-CoV-2 } \\
\text { plaque reduction } \\
\text { neutralization test }\end{array}$ & $\begin{array}{l}\text { One unit of } 300 \mathrm{~mL} \\
\text { ABO-compatible CP } \\
\text { was transfused on the } \\
\text { day of inclusion fol- } \\
\text { lowed with the second } \\
\text { plasma unit after } 5 \text { days } \\
\text { for patients with persis- } \\
\text { tent positive RT-PCR } \\
\text { tests }\end{array}$ & $\begin{array}{l}\text { There was no difference } \\
\text { in day- } 60 \text { mortality, } \\
\text { hospital stay }(P=.68) \text {, } \\
\text { or day- } 15 \text { disease } \\
\text { severity }(P=.58) \text { be- } \\
\text { tween CP-treated pa- } \\
\text { tients and patients on } \\
\text { standard care. The } \\
\text { study was discontinued } \\
\text { due to high neutralizing } \\
\text { antibody titers at hospi- } \\
\text { tal admission in the } \\
\text { majority of the study } \\
\text { population. }\end{array}$ & $\begin{array}{l}\text { No plasma-relat- } \\
\text { ed serious ad- } \\
\text { verse events } \\
\text { were observed }\end{array}$ \\
\hline
\end{tabular}




\begin{tabular}{|c|c|c|c|c|c|}
\hline Study design and studies & Population & Details of $\mathrm{CP}^{\mathrm{a}}$ & $\begin{array}{l}\text { Interventions and com- } \\
\text { parisons }\end{array}$ & $\begin{array}{l}\text { Outcomes/main find- } \\
\text { ings }\end{array}$ & $\begin{array}{l}\text { Adverse events } \\
\text { related to } \mathrm{CP} \\
\text { therapy }\end{array}$ \\
\hline Li et al 2020 [126] & $\begin{array}{l}103 \text { patients (median } \\
\text { age } 70 \text { years; } 60 \text { males, } \\
58.3 \% \text { ) with severe and } \\
\text { life-threatening } \\
\text { COVID-19 randomized } \\
\text { to receive CP in addi- } \\
\text { tion to standard treat- } \\
\text { ment ( } \mathrm{n}=52 \text { ) or standard } \\
\text { treatment (antiviral } \\
\text { medications, antibacteri- } \\
\text { al medications, steroids, } \\
\text { human immunoglobu- } \\
\text { lin, Chinese herbal } \\
\text { medicines, and other } \\
\text { medications) alone } \\
\text { (control; } \mathrm{n}=51 \text { ) }\end{array}$ & $\begin{array}{l}\text { Collected based on } \\
\text { routine plasma col- } \\
\text { lection procedures } \\
\text { via plasmapheresis } \\
\text { from adults aged } \\
\text { 18-55 years that } \\
\text { were suitable for } \\
\text { blood donation, } \\
\text { initially diagnosed } \\
\text { with COVID-19 } \\
\text { but with } 2 \text { negative } \\
\text { PCR results from } \\
\text { nasopharyngeal } \\
\text { swabs (at least } 24 \\
\text { h apart) prior to } \\
\text { hospital discharge, } \\
\text { discharged for } \geq 2 \\
\text { weeks from the } \\
\text { hospital, and had } \\
\text { no persisting } \\
\text { COVID-19 symp- } \\
\text { toms. CP S- } \\
\text { RBD-specific IgG } \\
\text { titer } \geq 1: 640 \text { corre- } \\
\text { lating to serum } \\
\text { neutralization titre } \\
\text { of } 1: 80\end{array}$ & $\begin{array}{l}\text { ABO-compatible CP } \\
\text { was transfused at ap- } \\
\text { proximately } 4-13 \\
\text { mL/kg of recipient } \\
\text { body weight and at ap- } \\
\text { proximately } 10 \mathrm{~mL} \text { for } \\
\text { the first } 15 \text { minutes, } \\
\text { which was then in- } \\
\text { creased to approximate- } \\
\text { ly } 100 \mathrm{~mL} \text { per hour } \\
\text { with close monitoring }\end{array}$ & $\begin{array}{l}\text { More clinical improve- } \\
\text { ment occurred within } \\
28 \text { days in the CP group } \\
\text { than in the control } \\
\text { group among those with } \\
\text { severe disease }(91.3 \% \\
\text { vs } 68.2 \% ; P=.03) \text { but } \\
\text { not for those with life- } \\
\text { threatening disease } \\
(20.7 \% \text { vs } 24.1 \% \text {; } \\
P=.83) \text {. There was a } \\
\text { higher negative conver- } \\
\text { sion rate of viral PCR } \\
\text { at } 72 \text { hours in the CP } \\
\text { group than in the con- } \\
\text { trol group ( } 87.2 \% \text { vs } \\
37.5 \% ; P<.001) .\end{array}$ & $\begin{array}{l}2 \text { patients in the } \\
\text { CP group experi- } \\
\text { enced adverse } \\
\text { events within } \\
\text { hours after } \\
\text { transfusion that } \\
\text { improved with } \\
\text { supportive care }\end{array}$ \\
\hline
\end{tabular}

${ }^{\mathrm{a}} \mathrm{CP}$ : convalescent plasma.

${ }^{\mathrm{b}} \mathrm{PCR}$ : polymerase chain reaction.

${ }^{\mathrm{c}} \mathrm{ICU}$ : intensive care unit.

${ }^{\mathrm{d}}$ ECMO: extracorporeal membranous oxygenation.

eELISA: enzyme-linked immunosorbent assay.

${ }^{\mathrm{f}} \mathrm{CT}$ : computed tomography.

g ASCT: autologous stem cell transplantation.

${ }^{\mathrm{h}}$ RT-PCR: real-time polymerase chain reaction.

${ }^{\mathrm{i}} \mathrm{S}-\mathrm{RBD}$ : spike protein receptor-binding domain.

${ }^{\mathrm{j} X L A}$ : X-linked agammagloblulinemia.

k $\mathrm{qPCR}$ : quantitative polymerase chain reaction.

${ }^{1}$ ARDS: acute respiratory distress syndrome.

mFA: Food and Drug Administration.

${ }^{\mathrm{n}}$ TRALI: transfusion-related acute lung injury.

${ }^{\circ} \mathrm{SAE}$ : serious adverse event.

PTACO: transfusion-associated circulatory overload.

${ }^{\mathrm{q}}$ SOT: solid organ transplant.

${ }^{\mathrm{r}} \mathrm{CRP}$ : C-reactive protein.

${ }^{\text {s}} \mathrm{LDH}$ : lactate dehydrogenase.

${ }^{\mathrm{t}} \mathrm{SCSS}$ : six-category scale score.

${ }^{\mathrm{u}} \mathrm{RCT}$ : randomized controlled trial.

\section{Patient Demographics}

A total of 36,379 patients, with most patients $(n=35,322)$ from a single study [97], have been treated with CP in all clinical studies included in this review. There is a patient heterogeneity across the clinical studies in terms of age (ranging from infant [81] and 6 [70] to 100 years [79]), gender, and different underlying diseases, in particular hypertension and diabetes $[114,122,124,294]$. Some case studies investigated CP therapy for COVID-19 in patients who were immune compromised or deficient [56,80,94,100,103,125].

A few studies reported the antibody titers of patients before $\mathrm{CP}$ transfusion, which varied from undetectable IgG RBD antibody levels ( $<1: 50$ serum dilution) to extremely high levels $(1: 25,600)$ [88]. Studies suggested that patients with low antibody levels may benefit more from CP therapy $[88,125]$. 


\section{Donor Selection and CP Antibody Titer}

Most individuals with previous laboratory-diagnosed SARS-CoV-2 infection developed measurable antibody responses and neutralizing antibodies. There is evidence for a significant decline in neutralizing antibody levels over time [280].

Studies suggest that the efficacy of CP depends on the antibody levels of the donor plasma and CP, with high antibody levels possibly conferring immediate immunity to recipients [122]. One key factor associated with CP therapy is the neutralizing antibody titer, and when the infused plasma has a high antibody titer, it may be of the greatest benefit $[88,97,99,113]$. Hence, it may be a prerequisite to find eligible donors who have high levels of neutralizing antibody.

Prior smaller studies have reported a variety of titer cut-offs $[105,115]$. The FDA has recommended that $\mathrm{CP}$ with a virus neutralizing antibody titer of $\geq 1: 160$ be used for therapeutic transfusion [295]. Recently, the FDA has updated its EUA to limit the authorization to the use of high titer CP for the treatment of hospitalized patients with COVID-19 early in the disease course and to those hospitalized who have impaired humoral immunity and cannot produce an adequate antibody response, and include additional tests to be used in the manufacture of COVID-19 CP [296]. Studies have reported the levels of $\mathrm{CP}$ antibody titer, ranging from no minimum neutralizing antibody titer level [96] to 1:640 [115], and an even wider range of RBD-specific IgG titer, from $<1: 160$ to $>1: 6000$ within the same study [88].

There was substantial heterogeneity in the antibody response among potential CP donors, but sex, age, and hospitalization emerged as factors that can be used to identify individuals with a high likelihood of having strong antiviral antibody levels [297]. In vitro testing of CP showed a tendency of higher neutralizing antibody titers from donors with increased disease severity, of advanced age, and of male sex; however, the clinical relevance of this difference needs to be investigated [109,270,276,277,283,284]. Moreover, pooling CP samples from many donors may prove more effective for increasing and standardizing anti-SARS-CoV-2 neutralizing antibody titers [19].

In addition, CP collection efforts should be organized around the temporal dynamics of the immune response to viral clearance and a rise in neutralizing antibody titer, with a recommended window for plasma collection beginning at 4 weeks after the resolution of symptoms and narrowing rapidly by 12 weeks [165].

\section{Timing and Dose}

One key factor associated with CP efficacy is the optimal treatment time point [115]. The phase of the disease that this treatment modality may be most beneficial is still a matter of some debate, with early versus intermediate-late stages of the cytokine storm reaction being associated with acute respiratory distress syndrome or other severe disease complications [298].

There was no therapeutic effect from CP treatment on severely or critically ill patients with COVID-19 more than 2 weeks after the onset of disease as reported by Liu et al [117]. However, $\mathrm{CP}$ therapy has been limited to patients with severe or critical COVID-19. The majority of patients were severe or critically ill with COVID-19, with only a few mild cases [79,90,109].

Similar to most viral illnesses, viremia in COVID-19 peaks in the first week of infection, and the primary immune response develops by days $10-14$, which is followed by virus clearance. Therefore, transfusion of $\mathrm{CP}$ at the early stage of disease theoretically should be more effective [114,121,124]. CP appears to be of greater clinical benefit when administered early in the course of disease than delaying transfusion under the development of severe disease $[63,108]$; in principle, the course of disease does not exceed 3 weeks [67]. Studies have found that, regardless of COVID-19 severity at time of transfusion, patients that received $\mathrm{CP}$ earlier in their course of disease showed lower mortality, more rapid viral clearance, and shorter hospital stays [92,113].

Based on the current findings, CP treatment should be given to patients with COVID-19 at the right phase or severity of illness and at the right time point. It is known that most patients with mild COVID-19 can recover without treatment, and CP may be an improper therapy for those patients. For patients with end-stage COVID-19, treatment with CP may be unable to avert a poor outcome, as demonstrated by the current findings [108,124,294]. Therefore, CP treatment may be more beneficial if used in patients who are potentially critically ill with COVID-19 at an early stage of the disease. Thus, early recognition of patients with COVID-19 who are likely to become critically ill is important for timely treatment with CP [124].

This is in line with one of the first published RCTs of CP, in which $\mathrm{Li}$ and colleagues [126] found that clinical improvement was limited to those without life-threatening disease, with $91 \%$ improvement in the plasma group compared to $68 \%$ in the control arm [294]. A large multicenter study involving 35,322 patients found significant reductions in 7- and 30-day mortality with early use of $\mathrm{CP}$ containing high levels of SARS-CoV-2-specific IgG antibodies in a subset of patients [97].

Transfusion volume ranged from 2x50 mL [110] to 8x300 mL [112]. Total antibody dose could be calculated as the transfused volume of $\mathrm{CP}$ multiplied by SARS-CoV-2 neutralizing antibody titer. CP dose has also been recognized as a key characteristic that may influence CP-associated outcomes [187]. One study showed that patients transfused with $400 \mathrm{~mL}$ of $\mathrm{CP}$ tended to turn faster to viral clearance than those who received $200 \mathrm{~mL}$ of CP [113].

\section{Safety}

All studies that assessed adverse events have reported no or minimal adverse events [102,206]. Of major interest is one of the first large trials published so far-concerning the safety of 5000 recipients - that has identified only limited and nonunexpected transfusion complications [95]. The case series study focused on the safety of CP transfusion in COVID-19 reported that, out of 5000 patients, there were 7 transfusion-associated circulatory overload (TACO), 11 transfusion-related lung injury (TRALI), and 3 severe allergic 
reactions. However, the reported low incidence of serious adverse effects might be due to an extremely short time frame of observation (4 hours) [194]. The latest update of the study involving 20,000 hospitalized adults with severe or life-threatening COVID-19 further demonstrated low adverse events because of the treatment, with 36 TACO, 21 TRALI, 21 severe allergic reactions, and 38 transfusion-related thromboembolic events [96]. Consistently, other studies reported no to minimal adverse events. Half of the case reports that assessed the safety of CP did not indicate any adverse events or complications related to its use. One case series study reported 5 serious adverse events in 4 out of 46 patients [118]. The controlled studies reported 15 adverse events out of 695 patients. Overall, among a total of 20,749 patients reported with safety data, the incidence of adverse events related to $\mathrm{CP}$ transfusion was less than $0.8 \%$, comparable or even lower than the incidence of adverse events related to plasma transfusions in other clinical settings [299]. There has been no evidence so far of antibody-mediated enhancement of disease in patients with COVID-19 treated with CP despite the concern that this might be a possibility in the presence of reactive but nonneutralizing antibodies against SARS-CoV-2 [170].

Although it is not yet clear whether the SARS-CoV-2 virus is transmitted by blood [300], donor selection criteria in compliance with existing policies and routine procedures should be met and pathogens reduction by solvent- or detergent-based treatments or light-based methods (especially for noncovered or detected in screening tests) should be performed in each donated plasma product as a standard for any plasma production $[157,230]$. Ultraviolet light and riboflavin used in the pathogen reduction process could effectively reduce SARS-CoV-2 in plasma and blood products without decreasing the quality of the blood products [301]. More studies have shown that the pathogen reduction processes did not alter neutralizing antibodies [156,272].

\section{Outcomes}

These were measured by SARS-CoV-2 negative PCR tests, improvements of clinical symptoms assessed by respiratory distress and fever, computed tomography, time to death, length of hospital stay, and mortality at discharge.

All case reports showed either viral load decrease/clearance or different extents of improvements of clinical symptoms with no mortality. Preliminary evidence from case reports and case series is favorable, as significant clinical and biochemical improvement and hospital discharge have been reported.

COVID-19 severity and underlying diseases affected the outcome of CP treatment. A patient with lymphoma who underwent autologous stem cell transplantation showed persistent SARS-CoV-2 viral shedding for 74 days, even with the administration of $\mathrm{CP}$ [77]. On the other hand, 1 study reported that 2 patients with long-term positive viral infection for 8 weeks showed substantial improvement after treatment with CP and ritonavir-boosted danoprevir [107]. Similarly, another study showed that $\mathrm{CP}$ therapy could rapidly reduce viral loads in more than half of 27 patients with prolonged positivity of SARS-CoV-2 for a median of 44 days after symptom onset [109]. It should be noted that most of these patients had mild COVID-19 symptoms.

Studies demonstrated that $\mathrm{CP}$ could effectively improve the respiratory symptoms of severe patients and help them wean from oxygen support. However, patients in extremely critical or life-threatening conditions could not benefit from CP $[63,122,124,294]$.

The case series reported a mortality rate of $24.4 \%$ in 35,666 patients, mainly from 1 study with 35,322 patients [97]. The case-control and randomized controlled studies included a total of 2289 patients in the control group and 695 patients in the $\mathrm{CP}$ group, and reported a total of $219(9.6 \%)$ and $63(9.1 \%)$ deaths in each group, respectively. The number of patients and the mortality rates varied remarkably among these studies, from 6 [124] to 1430 patients [122] and from $0 \%$ [115] to 93.3\% [124], respectively. The mortality at discharge [114] or at 28-day posttransfusion [121,294] have been reported as a primary outcome. Some studies showed improved survival for the CP group compared to its control $[115,117,122]$, more clinical improvements [115,117], and viral clearance [115,124]. The efficacy of CP on mortality, length of hospital stay, clinical improvement, and viral clearance was further analyzed by meta-analysis of controlled studies, as presented later.

\section{Quality Assessment of Clinical Studies}

As indicated in Table 3, 52 clinical studies showed overall weak quality, 9 had moderate quality, and 1 had strong quality. Patients often had underlying medical conditions (hypertension, diabetes). Case reports and series with limited number of patients were considered weak for selection of participants (high risk of selection bias). Some studies included only males with a total of 3 patients [117] or only pediatric patients with fewer than 4 children $[70,88]$ and therefore were judged to be weak for sample selection. Studies that targeted a specific group (eg, older populations, median age $>60$ years) were rated with moderate selection bias [122,124,125,294], while studies that selected patients with a broad range of ages and balanced gender and comorbidities $[114,121]$ were ranked as strong. 
Table 3. Quality assessment components and their rankings for clinical studies evaluated using the Effective Public Health Practice Project tool.

\begin{tabular}{|c|c|c|c|c|c|c|c|}
\hline Studies & Patient selection & Study design & Confounders & Blinding & $\begin{array}{l}\text { Data collection } \\
\text { methods }\end{array}$ & $\begin{array}{l}\text { Withdraws/ } \\
\text { dropouts }\end{array}$ & Overall \\
\hline Al Helali et al 2020 [65] & Weak & Weak & Weak & Weak & Weak & Strong & Weak \\
\hline Anderson et al 2020 [66] & Weak & Weak & Weak & Weak & Weak & Strong & Weak \\
\hline Bao et al 2020 [67] & Weak & Weak & Weak & Weak & Weak & Strong & Weak \\
\hline Cinar et al 2020 [68] & Weak & Weak & Weak & Weak & Moderate & Strong & Weak \\
\hline Clark et al 2020 [69] & Weak & Weak & Weak & Weak & Weak & Strong & Weak \\
\hline Figlerowicz et al 2020 [70] & Weak & Weak & Weak & Moderate & Moderate & Strong & Weak \\
\hline Grisolia et al 2020 [71] & Weak & Weak & Weak & Weak & Moderate & Strong & Weak \\
\hline Hahn et al 2020 [72] & Weak & Weak & Weak & Weak & Moderate & Strong & Weak \\
\hline Hartman et al 2020 [73] & Weak & Weak & Moderate & Weak & Weak & Moderate & Weak \\
\hline Im et al 2020 [74] & Weak & Weak & Weak & Weak & Weak & Strong & Weak \\
\hline Jafari et al 2020 [75] & Weak & Weak & Weak & Weak & Weak & Strong & Weak \\
\hline Jiang et al 2020 [76] & Weak & Weak & Weak & Weak & Moderate & Strong & Weak \\
\hline Karataş et al 2020 [77] & Weak & Weak & Weak & Weak & Weak & Strong & Weak \\
\hline Kong et al 2020 [79] & Weak & Weak & Weak & Moderate & Moderate & Strong & Weak \\
\hline Mira et al 2020 [80] & Weak & Weak & Moderate & Weak & Moderate & Strong & Weak \\
\hline $\begin{array}{l}\text { Soleimani and Soleimani } 2020 \\
\text { [82] }\end{array}$ & Weak & Weak & Weak & Weak & Weak & Strong & Weak \\
\hline Xu et al 2020 [83] & Weak & Weak & Weak & Weak & Weak & Strong & Weak \\
\hline Zhang et al 2020 [84] & Weak & Weak & Weak & Weak & Moderate & Strong & Weak \\
\hline Ahn et al 2020 [85] & Weak & Weak & Weak & Weak & Strong & Strong & Weak \\
\hline Abdullah et al 2020 [86] & Weak & Weak & Weak & Weak & Weak & Strong & Weak \\
\hline Bradfute et al 2020 [87] & Moderate & Weak & Weak & Weak & Moderate & Strong & Weak \\
\hline Diorio et al 2020 [88] & Weak & Weak & Weak & Weak & Strong & Strong & Weak \\
\hline Enzmann et al 2020 [89] & Weak & Weak & Weak & Weak & Weak & Strong & Weak \\
\hline Erkurt et al 2020 [90] & Moderate & Weak & Weak & Weak & Moderate & Strong & Weak \\
\hline Fung et al 2020 [56] & Weak & Weak & Weak & Weak & Moderate & Strong & Weak \\
\hline Gemici et al 2020 [91] & Moderate & Weak & Weak & Weak & Moderate & Strong & Weak \\
\hline Hartman et al 2020 [63] & Moderate & Weak & Weak & Weak & Weak & Strong & Weak \\
\hline Ibrahim et al 2020 [92] & Moderate & Weak & Weak & Weak & Strong & Strong & Weak \\
\hline Bobek et al 2020 [93] & Weak & Weak & Weak & Weak & Moderate & Strong & Weak \\
\hline Jin et al 2020 [94] & Weak & Weak & Weak & Weak & Moderate & Strong & Weak \\
\hline Joyner et al 2020 [95] & Strong & Weak & Weak & Weak & Weak & Strong & Weak \\
\hline Joyner et al 2020 [96] & Strong & Weak & Weak & Weak & Moderate & Strong & Weak \\
\hline Joyner et al 2020 [97] & Strong & Weak & Moderate & Weak & Strong & Strong & Weak \\
\hline Liu et al 2020 [98] & Weak & Weak & Weak & Weak & Moderate & Strong & Weak \\
\hline Maor et al 2020 [99] & Moderate & Weak & Weak & Weak & Strong & Strong & Weak \\
\hline Naeem et al 2020 [100] & Weak & Weak & Weak & Weak & Moderate & Strong & Weak \\
\hline Olivares-Gazca et al 2020 [101] & Weak & Weak & Weak & Weak & Moderate & Strong & Weak \\
\hline Pal et al 2020 [102] & Moderate & Weak & Weak & Weak & Moderate & Strong & Weak \\
\hline Rahman et al 2020 [103] & Weak & Weak & Weak & Weak & Moderate & Strong & Weak \\
\hline Salazar et al 2020 [104] & Weak & Weak & Weak & Weak & Strong & Strong & Weak \\
\hline
\end{tabular}




\begin{tabular}{|c|c|c|c|c|c|c|c|}
\hline Studies & Patient selection & Study design & Confounders & Blinding & $\begin{array}{l}\text { Data collection } \\
\text { methods }\end{array}$ & $\begin{array}{l}\text { Withdraws/ } \\
\text { dropouts }\end{array}$ & Overall \\
\hline Shen et al 2020 [105] & Moderate & Weak & Weak & Weak & Strong & Strong & Weak \\
\hline Tremblay et al 2020 [106] & Moderate & Weak & Weak & Weak & Moderate & Strong & Weak \\
\hline Wang et al 2020 [108] & Weak & Weak & Weak & Weak & Strong & Strong & Weak \\
\hline Wei et al 2020 [107] & Weak & Weak & Weak & Weak & Weak & Strong & Weak \\
\hline Wu et al 2020 [109] & Moderate & Weak & Weak & Weak & Strong & Strong & Weak \\
\hline Xi et al 2020 [110] & Weak & Weak & Weak & Weak & Weak & Moderate & Weak \\
\hline Ye et al 2020 [111] & Moderate & Weak & Weak & Weak & Strong & Strong & Weak \\
\hline Zhang et al 2020 [112] & Moderate & Weak & Weak & Weak & Moderate & Strong & Weak \\
\hline Zeng et al 2020 [113] & Weak & Weak & Weak & Weak & Strong & Strong & Weak \\
\hline Abolghasemi et al 2020 [114] & Strong & Moderate & Moderate & Weak & Strong & Strong & Moderate \\
\hline Duan et al 2020 [115] & Moderate & Moderate & Weak & Weak & Strong & Strong & Weak \\
\hline Hegerova et al 2020 [116] & Moderate & Moderate & Weak & Weak & Strong & Strong & Weak \\
\hline Liu et al 2020 [117] & Moderate & Moderate & Moderate & Moderate & Strong & Strong & Moderate \\
\hline Perotti et al 2020 [118] & Moderate & Moderate & Moderate & Weak & Strong & Moderate & Moderate \\
\hline Rasheed et al 2020 [119] & Moderate & Strong & Strong & Weak & Moderate & Strong & Moderate \\
\hline Roger et al 2020 [120] & Moderate & Moderate & Moderate & Weak & Strong & Strong & Moderate \\
\hline Salazar et al 2020 [121] & Strong & Moderate & Moderate & Weak & Strong & Strong & Moderate \\
\hline Xia et al 2020 [122] & Moderate & Moderate & Moderate & Weak & Moderate & Strong & Moderate \\
\hline Xiao et al 2020 [123] & Weak & Moderate & Moderate & Weak & Moderate & Strong & Weak \\
\hline Zeng et al 2020 [124] & Moderate & Moderate & Moderate & Weak & Moderate & Strong & Moderate \\
\hline Gharbharan et al 2020 [125] & Moderate & Strong & Strong & Weak & Strong & Strong & Moderate \\
\hline Li et al 2020 [126] & Moderate & Strong & Strong & Moderate & Strong & Strong & Strong \\
\hline
\end{tabular}

With respect to the study design, case reports and series were considered to be weak; case-control studies and RCTs were determined to be moderate and strong, respectively. The confounders for case reports and series studies were ranked weak given the uncontrolled nature of these studies involving other therapeutic treatments and supportive care and the use of other treatment regimens, including antiviral medications along with CP transfusion. Two different analytical methods were used to control for confounding in 1 case series study [97] subsequently determined to be of moderate risk for confounders. This component was ranked to be strong for RCTs and moderate for case-control studies, except for 1 study by Duan et al [115] given the uncertain characteristics of participants selected into the intervention group and the use of a historical control group.

As CP treatment was not blinded to either outcome assessors or study patients in most studies, the blinding component was judged to be weak except for the RCT by Li et al [126], where the evaluation of clinical outcomes was performed by an investigator who was blind to the treatment.

If there was no detailed $\mathrm{CP}$ therapy in terms of $\mathrm{CP}$ collection, neutralizing antibody or anti-SARS-CoV-2 IgG titers, timing and dose of the treatment, and valid measures of clinical outcomes, the data collection methods of the study were deemed to be weak. Some case reports did not provide any information for CP donators, antibody titers, and adverse events [66,67].
There were no dropouts in the case reports and case series. One case series study where all patients were followed up for only 7 days [118] was ranked as moderate. In the RCT reported by Gharbharan et al [125], all 86 patients had been followed for at least 15 days after inclusion, and 75 and 32 patients for at least 30 and 60 days, respectively.

Both RCTs were terminated prematurely due to the concerns over the potential benefit of $\mathrm{CP}$ in the study population with high neutralizing antibody titers $(\geq 1: 160)$ at baseline [125] and the lack of patients with COVID-19 to reach the planned recruitment target of 200 patients [294], resulting in an underpowered study sample size.

\section{Meta-analyses}

Figures 2-5 summarize the statistical analyses of pooled results from the controlled clinical studies addressing the efficacy of CP treatment for COVID-19. We found 13 controlled articles ( 2 RCTs and 11 cohort studies) assessing mortality, with a total of 695 and 2289 patients in the CP and control groups, respectively. CP reduced the mortality by half in COVID-19 (OR 0.48, 95\% CI 0.34-0.67; $\mathrm{I}^{2}=0$ ), as demonstrated in the forest plot (Figure 2).

However, fewer studies were available to assess the effects of $\mathrm{CP}$ treatment on the length of hospital stay, clinical improvement, and viral clearance. We identified only 6 studies 
(1 RCT and 5 cohort studies) reporting the length of hospital stay, with a total of 366 and 1735 patients in the $\mathrm{CP}$ and control groups, respectively (Figure 3 ). These studies had significant heterogeneity $\left(P<.001 ; \mathrm{I}^{2}=95 \%\right)$ and, when combined, did not show any effects of $\mathrm{CP}$ treatment on the length of hospital stay (mean difference $0.84,95 \% \mathrm{CI}-3.35$ to 5.02 days).

Similarly, 4 studies (2 RCTs and 2 cohort studies) assessed the clinical improvement with the number of patients in both $\mathrm{CP}$ and control groups. As depicted in Figure 4, a larger portion of the patients in the $\mathrm{CP}$ group showed improved clinical status compared to that in the control, but the difference was not statistically significant (OR $1.54,95 \%$ CI $0.79-3.01 ; \mathrm{I}^{2}=43 \%$ ).

Based on the 3 studies (1 RCT and 2 cohort studies) with a total of 63 and 65 patients in the $\mathrm{CP}$ and control groups, respectively, we found that the use of $\mathrm{CP}$ increased the viral clearance significantly (OR 26.21, 95\% CI 4.36-157.66; $\mathrm{I}^{2}=43 \%$ ) as shown in Figure 5.

Figure 2. Efficacy of CP treatment on mortality in COVID-19 patients. Data from 13 controlled clinical trials were pooled using an inverse variance method and analyzed using a random-effects model. Odds ratios and $95 \%$ CIs were used as statistical measures for mortality as a dichotomous outcome. CP: convalescent plasma.

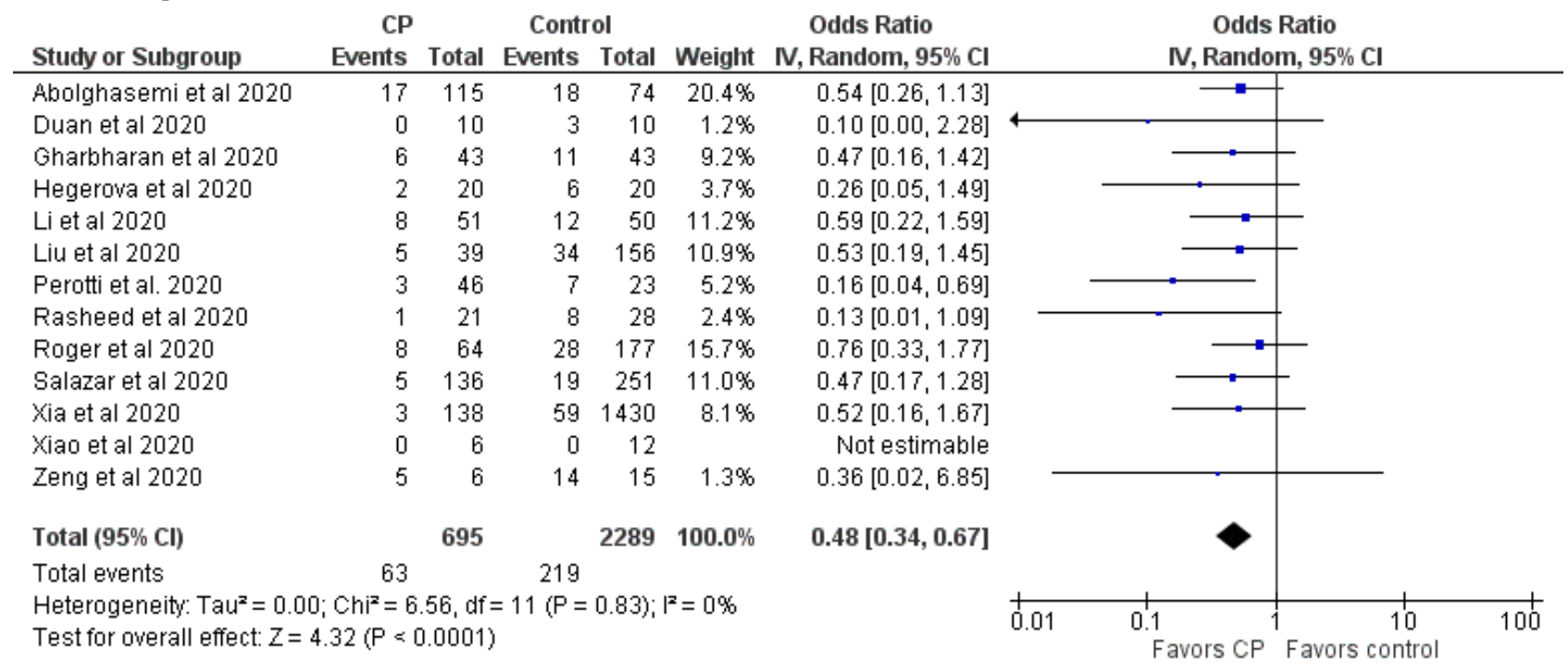

Figure 3. Efficacy of CP treatment on length of hospital stay in COVID-19 patients. Data from 6 controlled clinical trials were pooled using an inverse variance method and analyzed using a random-effects model. Means and SDs were the statistical measures used to describe the length of hospital stay. CP: convalescent plasma.

\begin{tabular}{|c|c|c|c|c|c|c|c|c|c|}
\hline \multirow[b]{2}{*}{ Study or Subgroup } & \multicolumn{3}{|c|}{ CP } & \multicolumn{3}{|c|}{ Control } & \multicolumn{2}{|r|}{ Mean Difference } & \multirow{2}{*}{$\begin{array}{c}\text { Mean Difference } \\
\text { IV, Random, } 95 \% \mathrm{Cl}\end{array}$} \\
\hline & Mean & SD & Total & Mean & SD & Total & Weight & IV, Random, 95\% Cl & \\
\hline Abolghasemi et al 2020 & 9.54 & 5.07 & 115 & 12.88 & 7.19 & 74 & $18.3 \%$ & $-3.34[-5.22,-1.46]$ & ] \\
\hline Hegerova et al 2020 & 13.83 & 5.16 & 20 & 9.83 & 5.16 & 20 & $17.1 \%$ & $4.00[0.80,7.20]$ & 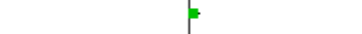 \\
\hline Li et al 2020 & 32.67 & 11.02 & 23 & 41.33 & 18.25 & 22 & $10.3 \%$ & $-8.66[-17.52,0.20]$ & -1 \\
\hline Roger et al 2020 & 7.83 & 4.17 & 64 & 8.67 & 5.8 & 177 & $18.6 \%$ & $-0.84[-2.17,0.49]$ & \\
\hline Xia et al 2020 & 22.67 & 10.45 & 138 & 14.33 & 9.63 & 1430 & $18.3 \%$ & $8.34[6.53,10.15]$ & $=$ \\
\hline Xiao et al 2020 & 24.2 & 3.3 & 6 & 22.6 & 1.7 & 12 & $17.5 \%$ & $1.60[-1.21,4.41]$ & \\
\hline Total $(95 \% \mathrm{Cl})$ & & & 366 & & & 1735 & $100.0 \%$ & $0.84[-3.35,5.02]$ & 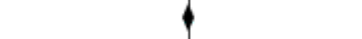 \\
\hline $\begin{array}{l}\text { Heterogeneity: } \operatorname{Tau}^{2}=24 \text {. } \\
\text { Test for overall effect: } Z=\end{array}$ & $\begin{array}{l}1 ; \mathrm{Chi}^{2}= \\
1.39(\mathrm{P}=\end{array}$ & $\begin{array}{l}=98.68 \\
=0.70)\end{array}$ & $d f=5($ & $(P<0$. & 001); & $=95 \%$ & & & $\begin{array}{ccccc}1 & 1 & 1 & 1 & 1 \\
-100 & -50 & 0 & 50 & 100 \\
& \text { Favors CP } & \text { Favors control }\end{array}$ \\
\hline
\end{tabular}

Figure 4. Efficacy of CP treatment on clinical improvement in COVID-19 patients. Data from 4 controlled clinical trials were pooled using an inverse variance method and analyzed using a random-effects model. Odds ratios and $95 \%$ CIs were used as statistical measures for clinical improvement as a dichotomous outcome. CP: convalescent plasma.

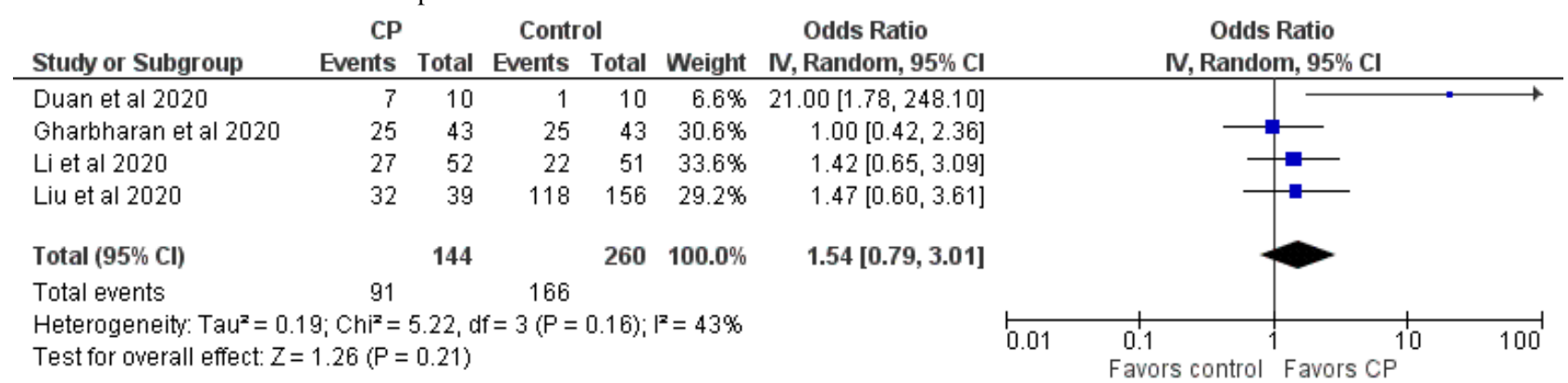


Figure 5. Efficacy of $\mathrm{CP}$ treatment on viral clearance in COVID-19 patients. Data from 3 controlled clinical trials were pooled using an inverse variance method and analyzed using a random-effects model. Odds ratios and 95\% CIs were used as statistical measures for viral clearance as a dichotomous outcome. CP: convalescent plasma.

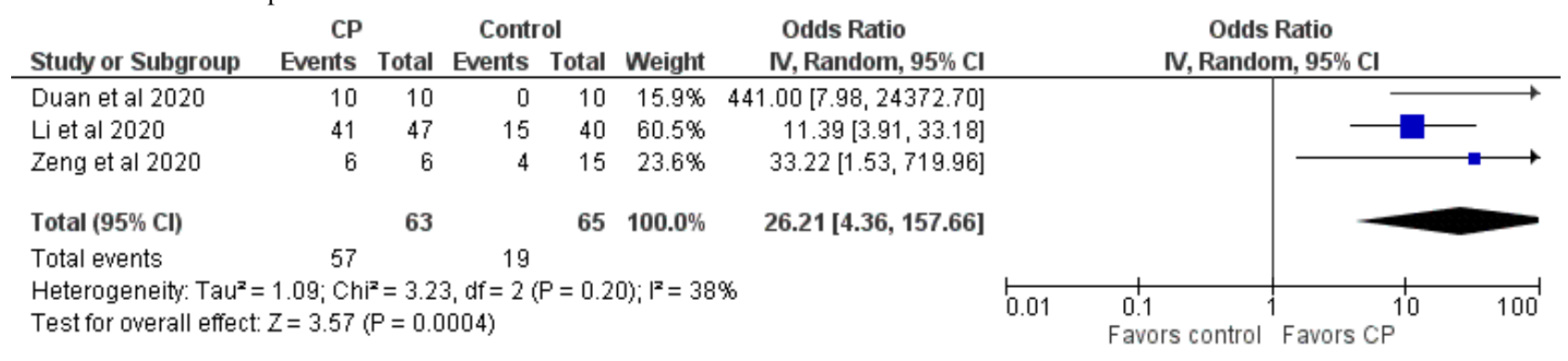

Except for the high heterogeneity among the studies on assessing the length of hospital stay $\left(\mathrm{I}^{2}=0.98 ; P<.001\right)$, the heterogeneity among the studies assessing the clinical improvement and viral clearance was mild $\left(\mathrm{I}^{2}=43 \%, P=.16\right.$ and $\mathrm{I}^{2}=38 \%, P=.20$, respectively). Furthermore, since the included studies on the efficacy of $\mathrm{CP}$ treatment for mortality are homogenous $\left(\mathrm{I}^{2}=0\right.$; $P=.99$ ), the overall effect on the mortality from the meta-analysis seems to be conclusive.

\section{Mechanisms of Action}

The biological basis for efficacy of CP entails the transfer of specific antiviral immunoglobulins (antibodies) and other bioactive substances in the plasma of patients in the convalescent phase of COVID-19 infection [233,302]. In theory, administration of $\mathrm{CP}$ containing high levels of polyclonal neutralizing antibodies (comprised mainly of $\mathrm{IgG}$, with smaller amounts of IgM, IgA) can confer immediate pathogen-specific protection by inhibiting viral infection in a susceptible person [303]. However, findings suggest considerable variation in antibody titers and the duration of protective anti-SARS-CoV-2 $\mathrm{IgG}$ and $\mathrm{IgM}$ immunity observed in recovered CP donors [304,305]. A recent population-based study of humoral immune responses to SARS-CoV-2 demonstrated that $>90 \%$ of people who recovered from COVID-19 were seropositive on virus-specific pan-immunoglobulin assays by day 25 , and hospitalized patients seroconverted more frequently than nonhospitalized people. Furthermore, anti-SARS-CoV-2 antibody titers remained stable in recovered patients for the next 2 months, suggesting a durable immunoglobulin response [306]. Aside from CP, pooled human immunoglobulins may also be prepared from plasma as a concentrated antibody-containing solution to be administered as intravenous, subcutaneous, or intramuscular immunoglobulin. These pooled plasma-derived immunoglobulin products benefit from the polyclonal response of each individual donor and from the interindividual variability in such responses [307]. In addition, purified, high-titer hyperimmune immunoglobulin formulations can be obtained from vaccinated or convalescing donors, which have known levels of plasma-derived neutralizing antibodies that may prove valuable against COVID-19 [33,207,225].

Although not fully elucidated, the protective mechanisms of $\mathrm{CP}$ are based on direct and indirect antiviral activities, including antibody neutralization of viral infectivity [233,307]. In the case of SARS-CoV-2 pathogenesis, the viral spike glycoprotein is critical to the dissemination and pathogenesis of the virus [308]. The spike protein mediates binding of SARS-CoV-2 to host cell ACE-2 surface receptors, thereby acting as the first step in cellular entry and infection. Several lines of evidence from studies of SARS-CoV and CoV-2 show that infected hosts produce neutralizing antibodies directed against the RBD of the homotrimeric spike protein and can block infection by preventing viral entry and subsequent replication [309]. Other beneficial immune effects of $\mathrm{CP}$ are thought to include enhanced antibody-dependent cellular cytotoxicity, complement activation, and phagocytosis, along with restoration of the vascular endothelial glycocalyx [34,200]. Moreover, a majority of convalescent patients display robust antiviral SARS-CoV-2-specific T cell responses, with enhanced in vivo priming and expansion of CD8+ cytotoxic T cells and a higher frequency of CD4+ memory $\mathrm{T}$ cells in those who recovered from severe COVID-19, which may provide long-term antiviral protection even if antibodies wane [310]. Therefore, T cells could help to control SARS-CoV-2 infection and serve as correlates of protective antiviral immunity [311].

As new strains of SARS-CoV-2 with several dominant mutations in the spike protein have been identified recently, crucial questions associated with the possible reinfection of recovered patients and the efficiencies of vaccines designed based on early epidemic strains have arisen [22]. Recent findings show that sera collected from convalescent COVID-19 patients in early 2020 vaccinated with $R B D$-based vaccines efficiently neutralize viral variants of D614G and B.1.1.7 but weakly neutralize those of 501Y.V2, suggesting a warning to recovered patients and developed vaccines [312]. These results show that, as mutations accumulate in the RBD, spike proteins may acquire an antigenic shift that enable SARS-CoV-2 variants with loss-of-neutralization potency in vitro against emerging variants and eventually resist the current vaccines. Therefore, intensive monitoring of virus mutations and timely adjustments to the spike sequences of designed vaccines and updated antibody cocktail therapies, targeting highly conserved regions, are required to control the viral pandemic [313].

\section{Discussion}

\section{Main Findings}

This systematic review summarizes a variety of evidence on the use of CP for treatment of COVID-19. Though the focus of this review was to identify and assess the quality of clinical studies reporting CP treatment for COVID-19, the broad search strategy identified a large number of studies related to various aspects of CP use, highlighting substantial research in this field. 
The data on this topic is being rapidly generated and reported. Most are commentary and review articles and protocol or guidance descriptions on the theme of $\mathrm{CP}$ treatments for COVID-19. The main findings according to each group of articles dealing with COVID-19 CP were:

1. Clinical studies: Overall, there were significant variations among the studies regarding the study design and population, the timing of initiation of $\mathrm{CP}$ transfusion, dosage and neutralizing antibody titer, and concomitant therapy. The quality of the current evidence on the use of $\mathrm{CP}$ for COVID-19 was low. However, there is a widespread belief that $\mathrm{CP}$ should be used given that no other efficacious treatment is currently available.

2. Commentary articles: This category mainly consisted of commentary and letter to the editor in addition to a few editorials and perspectives that collectively supported the use of CP for COVID-19 and suggested further clinical trials.

3. Review: The volume and the pace of the clinical trials launched to evaluate the safety and efficacy of CP against COVID-19 reflects the need for high-quality evidence for the therapy to be practiced by clinicians.

4. Protocol and guideline: This category of literature showed the importance for establishment of a CP production and storage transfusion program in a public health care network and a decision-making framework; the requirements applicable to plasma donors; and the standards for preparation, qualification, storage, distribution, and control of product use.

5. In vitro testing of $\mathrm{CP}$ : A variety of tests have been developed to measure the levels of $\mathrm{CP}$ antibodies. Generally, two methods have been most used to determine antibody titers of CP: ELISA for $\operatorname{IgG}$ and $\operatorname{IgM}$, and neutralization assay for neutralizing antibodies. ELISA-based antibody titers can correlate well with neutralizing titers.

Our meta-analysis of controlled studies showed significant reduction in mortality by $\mathrm{CP}$ therapy in comparison to controls. Similar meta-analysis of the efficacy of CP therapy on different types of infectious disease found a $44 \%$ reduction in the mortality of patients with COVID-19 [208]; a 25\% reduction in other severe acute respiratory infections [33]; and a $32 \%$ reduction in SARS-CoV infection, severe influenza, and Ebola infection [209]. In contrast, the meta-analysis from 4 RCTs on $\mathrm{CP}$ treatment for influenza infection ( $\mathrm{n}=572$ patients) showed no convincing effects on deaths [206]. Another recent systematic review of $1 \mathrm{RCT}$ and 3 controlled nonrandomized studies of CP therapy in patients with COVID-19 reported a potential reduction in mortality, time to death, and improvement of clinical symptoms but was unable to provide any opinion regarding the efficacy of $\mathrm{CP}$ treatment for COVID-19 due to paucity in quantitative synthesis [207].

Our meta-analysis showed no effect of CP on the length of hospital stay (mean difference), which is consistent with another meta-analysis of $3 \mathrm{RCT}$ s for the effect of CP on the length of hospitalization in other severe respiratory viral infections, as reported by Devasenapathy et al [206]. Other systematic reviewers reported mixed results of both reduced length of hospital stay and no effects on the length of hospitalization in SARS-CoV infection, severe influenza, and Ebola infection [209], suggesting that the effectiveness of $\mathrm{CP}$ in reducing hospital length of stay might be dependent on early administration of the therapy, and its use as prophylaxis is more likely to be beneficial than treating severe disease [33]. However, the optimal timing and dosage of CP therapy remains to be defined.

The insignificant effect of $\mathrm{CP}$ on the improvements of clinical COVID-19 symptoms is comparable to another systematic review and meta-analysis of 5 studies with a total of 259 patients with COVID-19, showing more clinically improved patients treated with $\mathrm{CP}$ than no $\mathrm{CP}$ treatment but was not statistically significant (OR 2.06, 95\% CI $0.8-4.9 ; \mathrm{I}^{2}=44 \%$ ) [208]. In contrast, the meta-analysis of 9 controlled and uncontrolled studies showed improved clinical status of patients with COVID-19 when compared to baseline (ROM 0.53, 95\% CI $0.36-0.79 ; P<.01 ; \mathrm{n}=149)$ [147].

The significant increase in the viral clearance is also consistent with the other meta-analysis of 2 studies with a total of 144 patients, suggesting that the use of $\mathrm{CP}$ helps in viral clearance significantly [208], and with the meta-analysis of 9 controlled and uncontrolled studies showing reduced viral loads [147].

Various tools have been developed for quality assessment involving slightly different components and ranking criteria [314]. We used the EPHPP tool as it can be used for all types of clinical studies. This is a generic tool used to evaluate a variety of intervention study designs such as RCTs, before-and-after, and case-control studies [62]. A study has shown differences in quality assessment for RCTs between the EPHPP and the Cochrane Collaboration Risk of Bias tool [315]. Overall, clinical studies and systematic reviews have confirmed that $\mathrm{CP}$ caused few or no serious adverse events with low-quality evidence.

Consistent with other reviews [207,208], our quality appraisal showed that the present studies on the efficacy of CP are generally of low quality, although there are certain agreements and discrepancies between our assessment and others on the overall quality of case and randomized controlled studies on the use of CP for COVID-19, as different assessment tools have been used. Only 1 high-quality (low risk of bias in the underlying study results) RCT by Li et al [126] was identified in our assessment using the EPHPP tool, which is in agreement with the assessment in the systematic review by Sarkar et al [208], but was rated to be unclear in another systematic review by Piechotta et al [207], even though both reviews used the same Cochrane risk-of-bias tool (RoB 2.0) for the RCT.

The overall quality of the case-control studies in our assessment lies in between the risk of bias assessed by other two systematic reviews conducted by Piechotta et al [207] and Sarkar et al [208]. Specifically, the study by Duan et al [115] was considered weak in our quality assessment but was critical as assessed by Piechotta et al [207] and moderate risk of bias by Sarkar et al [208] in their reviews. The case-control study reported by Liu et al [117] was of moderate quality in our assessment but was critical and had a low risk of bias as assessed by Piechotta et al 
[207] and Sarkar et al [208], respectively, using the same Risk of Bias in Non-randomized Studies-of Interventions. The case-control study reported by Zeng et al [124] was moderate in our assessment, agreeing with the assessment in the systematic review by Sarkar et al [208], but was rated to be a critical risk of bias in the systematic review by Piechotta et al [207]. In addition to controlled and randomized studies, EPHPP could be used to assess the quality of case reports and series studies [62]. The overall quality of all case reports and series were weak based on our assessment.

Considering the promising evidence from existing clinical data, there is a clear need for RCTs on large patient numbers to evaluate the efficacy of CP therapy. Apart from sample size and the noncomparative, nonrandomized study design, numerous limitations hamper the interpretation of the aforementioned studies, such as the superimposition of effects mediated by other antiviral treatments, antibiotics, and glucocorticoids administered concomitantly with CP. As a whole, these studies indicate that patients receiving transfusions earlier than 14 days post infection may benefit from CP treatment [228,230].

\section{Limitations}

There are 2 systematic reviews and meta-analysis to appraise the literature on CP therapy for patients with COVID-19. However, this review covers the latest literature as of the date of our manuscript submission and provides insights about various aspects for the subject on the use of CP for COVID-19 that needs further investigation. The primary limitation of this review is that most data identified are nonrandomized (only 2 out of 64 clinical studies were randomized, with only 1 being of high quality), and therefore, confounding is highly inevitable. Furthermore, study populations, interventions, and measured outcomes have important clinical and methodological heterogeneity, which reflects an overall low to moderate quality of evidence identified by the appropriate quality assessment tool.

Publication bias may be another potential limitation given that the majority of early clinical studies on COVID-19 lacked original data, and those that did were rushed and did not include the appropriate measures to reduce bias [316]. Among the 243 papers included in this review, 32.5\% $(\mathrm{n}=79)$ were commentaries, $18.9 \%(n=46)$ were reviews, and $7.8 \%(n=19)$ were protocols that did not contain any new data. We then evaluated the quality of the original clinical studies using the validated tool and found that more than $80 \%(52 / 64)$ were at risk of bias, mainly because of few participants, unrepresentative patient selection, poor study design, no control of confounders, and no blinding.

\section{Future Directions}

We summarized various aspects of the evidence on the use of CP in patients with COVID-19. However, important gaps in knowledge remain. Notably, the following areas require further investigation.

Well-designed prospective observational studies, preferentially RCTs, with well-defined characteristics for both CP donors and recipients are warranted to answer questions concerning the effects on mortality or other important clinical outcomes such as improvement in symptoms and respiratory status. The placebo or control should include standard-of-care or normal fresh frozen plasma. The plasma exchange has shown therapeutic effects for severe COVID-19 acute respiratory distress syndrome with multiple organ failure [317].

In vitro testing showed variable or diverse neutralizing antibody titers among individual donors, suggesting that an adequate pooling strategy of plasma units from different donors could reduce the variability of neutralizing antibody titers of $\mathrm{CP}$ and compensate deviations of individual antibody titers [289]. Clinical studies on the safety and efficacy of pooled CP should be conducted.

The COVID-19 pandemic has substantially reduced the national ability to provide blood products for medical care in an emergency [318], which further highlights the need to secure a stockpile of blood products with a long shelf life (eg, freeze-dried plasma) to be self-sufficient in a national crisis. Current $\mathrm{CP}$ protocols specify that, once thawed, $\mathrm{CP}$ may be stored for up to 5 days at $4{ }^{\circ} \mathrm{C}$, similar to that of fresh frozen plasma. A recent study has demonstrated long-term stability of anti-SARS-CoV-2 spike antibodies in donor CP for 42 days when stored under refrigerated conditions [291]. There will be a need to stockpile freeze-dried CP for future waves of the pandemic for several years. Additionally, global concern over the potential for future waves of infection to occur before effective vaccines or drug therapies are available has many looking at other biological sources for large-scale production of neutralizing SARS-CoV-2 antibodies. Taking this into consideration, we are developing COVID-19 convalescent freeze-dried plasma. As this is a pooled plasma product of 10 donors, we also hypothesize that convalescent freeze-dried plasma will have higher anti-SARS-CoV-2 neutralizing antibody titers and activity than single donor CP. As well, this product may be administered in a hypertonic solution for those patients who cannot tolerate large volume $\mathrm{CP}$ transfusions.

\section{Conclusions}

There is still limited evidence but accumulating interest in $\mathrm{CP}$ treatment for COVID-19. The theoretical reasons for the likely efficacy of passive immunization, the urgent need felt by clinicians worldwide for effective treatment options for COVID-19, and the promising results offered mainly by retrospective clinical studies must be balanced against the lack of efficacy in the RCTs of $\mathrm{CP}$ and hyperimmune globulin therapy in severe influenza and COVID-19.

CP may be of greatest benefit for patients who are early in their illness and have not yet generated endogenous antibodies, and when the infused CP has a high antibody titer. Recurring observations suggested that treatment with $\mathrm{CP}$ within 4-5 days of symptom onset might be more effective than later treatment.

Our systematic review and analysis emphasizes the low quality of clinical studies. These studies could provide important lessons that should inform the planning of adequately powered and properly designed RCTs to evaluate the promise of CP therapy for patients with COVID-19.

Future research is necessary to fill the obvious knowledge gaps regarding $\mathrm{CP}$ treatment for patients with COVID-19. In brief, 
we offered recommendations around the need for a large-scale properly designed RCT, the potential prophylactic use of $\mathrm{CP}$, selection criteria for both $\mathrm{CP}$ donors and recipients, development of antibodies with higher potency than $\mathrm{CP}$, and freeze-dried $\mathrm{CP}$ as a long-term strategy against the pandemic.

\section{Acknowledgments}

We would like to thank Defence Research and Development Canada for funding support.

\section{Conflicts of Interest}

None declared.

\section{Multimedia Appendix 1}

Supplemental Table 1.

[DOCX File, 486 KB-Multimedia Appendix 1]

\section{References}

1. Zhu N, Zhang D, Wang W, Li X, Yang B, Song J, China Novel Coronavirus Investigating and Research Team. A novel coronavirus from patients with pneumonia in China, 2019. N Engl J Med 2020 Feb 20;382(8):727-733 [FREE Full text] [doi: 10.1056/NEJMoa2001017] [Medline: $\underline{\text { 31978945] }}$

2. Yesudhas D, Srivastava A, Gromiha MM. COVID-19 outbreak: history, mechanism, transmission, structural studies and therapeutics. Infection 2020 Sep 04:199-213 [FREE Full text] [doi: 10.1007/s15010-020-01516-2] [Medline: 32886331]

3. Perlman S. Another decade, another coronavirus. N Engl J Med 2020 Feb 20;382(8):760-762 [FREE Full text] [doi: 10.1056/NEJMe2001126] [Medline: $\underline{\text { 31978944] }}$

4. Struyf T, Deeks J, Dinnes J, Takwoingi Y, Davenport C, Leeflang M, Cochrane COVID-19 Diagnostic Test Accuracy Group. Signs and symptoms to determine if a patient presenting in primary care or hospital outpatient settings has COVID-19 disease. Cochrane Database Syst Rev 2020 Jul 07;7:CD013665 [FREE Full text] [doi: 10.1002/14651858.CD013665] [Medline: $\underline{\text { 32633856] }}$

5. Hasani H, Mardi S, Shakerian S, Taherzadeh-Ghahfarokhi N, Mardi P. The novel coronavirus disease (COVID-19): a PRISMA systematic review and meta-analysis of clinical and paraclinical characteristics. Biomed Res Int 2020;2020:3149020. [doi: 10.1155/2020/3149020] [Medline: 32851061]

6. Rajgor DD, Lee MH, Archuleta S, Bagdasarian N, Quek SC. The many estimates of the COVID-19 case fatality rate. Lancet Infect Dis 2020 Jul;20(7):776-777 [FREE Full text] [doi: 10.1016/S1473-3099(20)30244-9] [Medline: 32224313]

7. Del Rio C, Collins LF, Malani P. Long-term health consequences of COVID-19. JAMA 2020 Oct 05:1723-1724. [doi: 10.1001/jama.2020.19719] [Medline: 33031513]

8. Chattu VK, Adisesh A, Yaya S. Canada's role in strengthening global health security during the COVID-19 pandemic. Glob Health Res Policy 2020;5:16 [FREE Full text] [doi: 10.1186/s41256-020-00146-3] [Medline: $\underline{32328533}$ ]

9. Gebru A, Birhanu T, Wendimu E, Ayalew A, Mulat S, Abasimel H, et al. Global burden of COVID-19: situational analyis and review. Hum Antibodies 2020 Jul 24:1. [doi: 10.3233/HAB-200420] [Medline: 32804122]

10. Rizwan K, Rasheed T, Khan SA, Bilal M, Mahmood T. Current perspective on diagnosis, epidemiological assessment, prevention strategies, and potential therapeutic interventions for severe acute respiratory infections caused by 2019 novel coronavirus (SARS-CoV-2). Hum Vaccin Immunother 2020 Dec 01;16(12):3001-3010. [doi: 10.1080/21645515.2020.1794684] [Medline: 32881628]

11. Kaddoura M, AlIbrahim M, Hijazi G, Soudani N, Audi A, Alkalamouni H, et al. COVID-19 therapeutic options under investigation. Front Pharmacol 2020;11:1196. [doi: 10.3389/fphar.2020.01196] [Medline: 32848795]

12. Koyama T, Weeraratne D, Snowdon J, Parida L. Emergence of drift variants that may affect COVID-19 vaccine development and antibody treatment. Pathogens 2020 Apr 26;9(5):324 [FREE Full text] [doi: 10.3390/pathogens9050324] [Medline: $\underline{32357545]}$

13. Liu W, Zhou P, Chen K, Ye Z, Liu F, Li X, et al. Efficacy and safety of antiviral treatment for COVID-19 from evidence in studies of SARS-CoV-2 and other acute viral infections: a systematic review and meta-analysis. CMAJ 2020 Jul 06;192(27):E734-E744 [FREE Full text] [doi: 10.1503/cmaj.200647] [Medline: 32493740]

14. Meo SA, Zaidi SZA, Shang T, Zhang JY, Al-Khlaiwi T, Bukhari IA, et al. Biological, molecular and pharmacological characteristics of chloroquine, hydroxychloroquine, convalescent plasma, and remdesivir for COVID-19 pandemic: A comparative analysis. J King Saud Univ Sci 2020 Oct;32(7):3159-3166 [FREE Full text] [doi: 10.1016/j.jksus.2020.09.002] [Medline: 32921965]

15. WHO Rapid Evidence Appraisal for COVID-19 Therapies (REACT) Working Group, Sterne JAC, Murthy S, Diaz JV, Slutsky AS, Villar J, et al. Association between administration of systemic corticosteroids and mortality among critically ill patients with COVID-19: a meta-analysis. JAMA 2020 Oct 06;324(13):1330-1341 [FREE Full text] [doi: 10.1001/jama.2020.17023] [Medline: 32876694] 
16. Yang Z, Liu J, Zhou Y, Zhao X, Zhao Q, Liu J. The effect of corticosteroid treatment on patients with coronavirus infection: a systematic review and meta-analysis. J Infect 2020 Jul;81(1):e13-e20 [FREE Full text] [doi: 10.1016/j.jinf.2020.03.062] [Medline: $\underline{32283144]}$

17. Mellet J, Pepper MS. A COVID-19 vaccine: big strides come with big challenges. Vaccines (Basel) 2021 Jan 11;9(1):39 [FREE Full text] [doi: 10.3390/vaccines9010039] [Medline: 33440895]

18. Singh R, Kang A, Luo X, Jeyanathan M, Gillgrass A, Afkhami S, et al. COVID-19: current knowledge in clinical features, immunological responses, and vaccine development. FASEB J 2021 Mar;35(3):e21409 [FREE Full text] [doi: 10.1096/fj.202002662R] [Medline: 33577115]

19. Machhi J, Herskovitz J, Senan AM, Dutta D, Nath B, Oleynikov MD, et al. The natural history, pathobiology, and clinical manifestations of SARS-CoV-2 infections. J Neuroimmune Pharmacol 2020 Sep;15(3):359-386 [FREE Full text] [doi: 10.1007/s11481-020-09944-5] [Medline: 32696264]

20. Wherry EJ, Jaffee EM, Warren N, D'Souza G, Ribas A, AACR COVID-19 and Cancer Task Force. How did we get a COVID-19 vaccine in less than 1 year? Clin Cancer Res 2021 Feb 04:1. [doi: 10.1158/1078-0432.CCR-21-0079] [Medline: $\underline{33542081]}$

21. Forni G, Mantovani A, COVID-19 Commission of Accademia Nazionale dei Lincei, Rome. COVID-19 vaccines: where we stand and challenges ahead. Cell Death Differ 2021 Feb;28(2):626-639 [FREE Full text] [doi: 10.1038/s41418-020-00720-9] [Medline: 33479399]

22. Mascola JR, Graham BS, Fauci AS. SARS-CoV-2 viral variants-tackling a moving target. JAMA 2021 Feb 11:1. [doi: 10.1001/jama.2021.2088] [Medline: 33571363]

23. Su Z, Wen J, McDonnell D, Goh E, Li X, Šegalo S, et al. Vaccines are not yet a silver bullet: the imperative of continued communication about the importance of COVID-19 safety measures. Brain Behav Immun Health 2021 Mar;12:100204 [FREE Full text] [doi: 10.1016/j.bbih.2021.100204] [Medline: 33495754$]$

24. Su S, Wang Q, Jiang S. Facing the challenge of viral mutations in the age of pandemic: developing highly potent, broad-spectrum, and safe COVID-19 vaccines and therapeutics. Clin Transl Med 2021 Jan;11(1):e284. [doi: 10.1002/ctm2.284] [Medline: 33463059]

25. Bajwah S, Wilcock A, Towers R, Costantini M, Bausewein C, Simon ST, et al. Managing the supportive care needs of those affected by COVID-19. Eur Respir J 2020 Apr;55(4):2000815. [doi: 10.1183/13993003.00815-2020] [Medline: 32269090]

26. Pavia CG, Wormser GP. Passive immunization and its rebirth in the era of the COVID-19 pandemic. Int J Antimicrob Agents 2021 Mar;57(3):106275 [FREE Full text] [doi: 10.1016/j.ijantimicag.2020.106275] [Medline: $\underline{33400975]}$

27. Focosi D, Anderson AO, Tang JW, Tuccori M. Convalescent plasma therapy for COVID-19: state of the art. Clin Microbiol Rev 2020 Sep 16;33(4):e00072-e00020 [FREE Full text] [doi: 10.1128/CMR.00072-20] [Medline: $\underline{32792417]}$

28. Chen L, Xiong J, Bao L, Shi Y. Convalescent plasma as a potential therapy for COVID-19. Lancet Infect Dis 2020 Apr;20(4):398-400 [FREE Full text] [doi: 10.1016/S1473-3099(20)30141-9] [Medline: 32113510]

29. Morabito CJ, Gangadharan B. Active therapy with passive immunotherapy may be effective in the fight against COVID-19. Clin Transl Sci 2020 Sep;13(5):835-837 [FREE Full text] [doi: 10.1111/cts.12816] [Medline: 32420691]

30. AminJafari AS, Ghasemi S. The possible of immunotherapy for COVID-19: a systematic review. Int Immunopharmacol 2020 Jun;83:106455 [FREE Full text] [doi: 10.1016/j.intimp.2020.106455] [Medline: 32272396]

31. Marson P, Cozza A, De Silvestro G. The true historical origin of convalescent plasma therapy. Transfus Apher Sci 2020 Oct;59(5):102847 [FREE Full text] [doi: 10.1016/j.transci.2020.102847] [Medline: 32565057]

32. Mansourabadi AH, Sadeghalvad M, Mohammadi-Motlagh H, Rezaei N. The immune system as a target for therapy of SARS-CoV-2: a systematic review of the current immunotherapies for COVID-19. Life Sci 2020 Oct 01;258:118185 [FREE Full text] [doi: 10.1016/j.lfs.2020.118185] [Medline: $\underline{32750438]}$

33. Mair-Jenkins J, Saavedra-Campos M, Baillie JK, Cleary P, Khaw F, Lim WS, Convalescent Plasma Study Group. The effectiveness of convalescent plasma and hyperimmune immunoglobulin for the treatment of severe acute respiratory infections of viral etiology: a systematic review and exploratory meta-analysis. J Infect Dis 2015 Jan 01;211(1):80-90 [FREE Full text] [doi: 10.1093/infdis/jiu396] [Medline: 25030060]

34. Casadevall AL, Pirofski LA. The convalescent sera option for containing COVID-19. J Clin Invest 2020 Apr 01;130(4):1545-1548. [doi: 10.1172/JCI138003] [Medline: 32167489]

35. Marano G, Vaglio S, Pupella S, Facco G, Catalano L, Liumbruno GM, et al. Convalescent plasma: new evidence for an old therapeutic tool? Blood Transfus 2016 Mar;14(2):152-157. [doi: 10.2450/2015.0131-15] [Medline: 26674811]

36. Montelongo-Jauregui D, Vila T, Sultan AS, Jabra-Rizk MA. Convalescent serum therapy for COVID-19: a 19th century remedy for a 21st century disease. PLoS Pathog 2020 Aug;16(8):e1008735 [FREE Full text] [doi: 10.1371/journal.ppat.1008735] [Medline: 32785259]

37. Luke TC, Kilbane EM, Jackson JL, Hoffman SL. Meta-analysis: convalescent blood products for Spanish influenza pneumonia: a future H5N1 treatment? Ann Intern Med 2006 Oct 17;145(8):599-609 [FREE Full text] [doi: 10.7326/0003-4819-145-8-200610170-00139] [Medline: 16940336]

38. Watson J, Pati S, Schreiber M. Plasma transfusion: history, current realities, and novel improvements. Shock 2016 Nov;46(5):468-479. [doi: 10.1097/SHK.0000000000000663] [Medline: 27380536] 
39. Hung IF, To KK, Lee C, Lee K, Chan K, Yan W, et al. Convalescent plasma treatment reduced mortality in patients with severe pandemic influenza A (H1N1) 2009 virus infection. Clin Infect Dis 2011 Feb 15;52(4):447-456 [FREE Full text] [doi: 10.1093/cid/ciq106] [Medline: 21248066]

40. Keller MA, Stiehm ER. Passive immunity in prevention and treatment of infectious diseases. Clin Microbiol Rev 2000 Oct;13(4):602-614 [FREE Full text] [doi: 10.1128/cmr.13.4.602-614.2000] [Medline: 11023960]

41. Pérez-Cameo C, Marín-Lahoz J. Serosurveys and convalescent plasma in COVID-19. EClinicalMedicine 2020 Jun;23:100370 [FREE Full text] [doi: 10.1016/j.eclinm.2020.100370] [Medline: 32632410]

42. Lung T, Kazatchkine MD, Risch L, Risch M, Nydegger UE. A consideration of convalescent plasma and plasma derivatives in the care of severely-ill patients with COVID-19. Transfus Apher Sci 2020 Oct;59(5):102936 [FREE Full text] [doi: 10.1016/j.transci.2020.102936] [Medline: $\underline{32919880]}$

43. Sheridan C. Convalescent serum lines up as first-choice treatment for coronavirus. Nat Biotechnol 2020 Jun;38(6):655-658. [doi: 10.1038/d41587-020-00011-1] [Medline: 32358594]

44. Tanne JH. Covid-19: FDA approves use of convalescent plasma to treat critically ill patients. BMJ 2020 Mar 26;368:m1256. [doi: 10.1136/bmj.m1256] [Medline: $\underline{\text { 32217555] }}$

45. Emergency use authorization of medical products and related authorities: guidance for industry and other stakeholders. US Food and Drug Administration. URL: http://www.fda.gov/media/97321/download [accessed 2020-09-27]

46. Hossen MS, Barek MA, Jahan N, Safiqul Islam M. A review on current repurposing drugs for the treatment of COVID-19: reality and challenges. SN Compr Clin Med 2020 Aug 31:1-13 [FREE Full text] [doi: 10.1007/s42399-020-00485-9] [Medline: 32904710 ]

47. Rubin R. Testing an old therapy against a new disease: convalescent plasma for COVID-19. JAMA 2020 Jun 02;323(21):2114-2117. [doi: 10.1001/jama.2020.7456] [Medline: 32352484]

48. Weinreich DM, Sivapalasingam S, Norton T, Ali S, Gao H, Bhore R, Trial Investigators. REGN-COV2, a neutralizing antibody cocktail, in outpatients with Covid-19. N Engl J Med 2021 Jan 21;384(3):238-251 [FREE Full text] [doi: 10.1056/NEJMoa2035002] [Medline: 33332778]

49. Chen P, Nirula A, Heller B, Gottlieb RL, Boscia J, Morris J, BLAZE-1 Investigators. SARS-CoV-2 neutralizing antibody LY-CoV555 in outpatients with Covid-19. N Engl J Med 2021 Jan 21;384(3):229-237 [FREE Full text] [doi: 10.1056/NEJMoa2029849] [Medline: 33113295]

50. Singh B, Ryan H, Kredo T, Chaplin M, Fletcher T. Chloroquine or hydroxychloroquine for prevention and treatment of COVID-19. Cochrane Database Syst Rev 2021 Feb 12;2:CD013587. [doi: 10.1002/14651858.CD013587.pub2] [Medline: $\underline{33624299]}$

51. Juul S, Nielsen EE, Feinberg J, Siddiqui F, Jørgensen CK, Barot E, et al. Interventions for treatment of COVID-19: a living systematic review with meta-analyses and trial sequential analyses (The LIVING Project). PLoS Med 2020 Sep;17(9):e1003293 [FREE Full text] [doi: 10.1371/journal.pmed.1003293] [Medline: 32941437]

52. Choi JY. Convalescent plasma therapy for coronavirus disease 2019. Infect Chemother 2020 Sep;52(3):307-316 [FREE Full text] [doi: 10.3947/ic.2020.52.3.307] [Medline: 32989938]

53. Joyner MJ, Carter RE, Senefeld JW, Klassen SA, Mills JR, Johnson PW, et al. Convalescent plasma antibody levels and the risk of death from Covid-19. N Engl J Med 2021 Mar 18;384(11):1015-1027 [FREE Full text] [doi: 10.1056/NEJMoa2031893] [Medline: $\underline{\text { 33523609] }}$

54. Libster R, Pérez Marc G, Wappner D, Coviello S, Bianchi A, Braem V, Fundación INFANT-COVID-19 Group. Early high-titer plasma therapy to prevent severe Covid-19 in older adults. N Engl J Med 2021 Feb 18;384(7):610-618 [FREE Full text] [doi: 10.1056/NEJMoa2033700] [Medline: $\underline{\text { 33406353] }}$

55. Bloch E, Shoham S, Casadevall A, Sachais B, Shaz B, Winters J, et al. Deployment of convalescent plasma for the prevention and treatment of COVID-19. J Clin Invest 2020 Jun 01;130(6):2757-2765. [doi: 10.1172/JCI138745] [Medline: 32254064]

56. Fung M, Nambiar A, Pandey S, Aldrich JM, Teraoka J, Freise C, et al. Treatment of immunocompromised COVID-19 patients with convalescent plasma. Transpl Infect Dis 2020 Sep 29:e13477 [FREE Full text] [doi: 10.1111/tid.13477] [Medline: 32989856]

57. Wooding DJ, Bach H. Treatment of COVID-19 with convalescent plasma: lessons from past coronavirus outbreaks. Clin Microbiol Infect 2020 Oct;26(10):1436-1446 [FREE Full text] [doi: 10.1016/j.cmi.2020.08.005] [Medline: 32791241]

58. Malani AN, Sherbeck JP, Malani PN. Convalescent plasma and COVID-19. JAMA 2020 Aug 04;324(5):524. [doi: 10.1001/jama.2020.10699] [Medline: $\underline{\text { 32530454] }}$

59. Tiberghien P, de Lamballerie X, Morel P, Gallian P, Lacombe K, Yazdanpanah Y. Collecting and evaluating convalescent plasma for COVID-19 treatment: why and how? Vox Sang 2020 Aug;115(6):488-494. [doi: 10.1111/vox.12926] [Medline: $\underline{32240545]}$

60. Liberati A, Altman DG, Tetzlaff J, Mulrow C, Gøtzsche PC, Ioannidis JPA, et al. The PRISMA statement for reporting systematic reviews and meta-analyses of studies that evaluate healthcare interventions: explanation and elaboration. BMJ 2009 Jul 21;339:b2700 [FREE Full text] [doi: 10.1136/bmj.b2700] [Medline: 19622552]

61. Grant MA, Booth A. A typology of reviews: an analysis of 14 review types and associated methodologies. Health Info Libr J 2009 Jun;26(2):91-108. [doi: 10.1111/j.1471-1842.2009.00848.x] [Medline: 19490148] 
62. Thomas B, Ciliska D, Dobbins M, Micucci S. A process for systematically reviewing the literature: providing the research evidence for public health nursing interventions. Worldviews Evid Based Nurs 2004;1(3):176-184. [doi: 10.1111/j.1524-475X.2004.04006.x] [Medline: 17163895$]$

63. Hartman WR, Hess AS, Connor JP. Hospitalized COVID-19 patients treated with convalescent plasma in a mid-size city in the mid west. Res Square. Preprint posted online on August 6, 2020. [doi: 10.21203/rs.3.rs-54167/v1] [Medline: 32793897]

64. Wan X, Wang W, Liu J, Tong T. Estimating the sample mean and standard deviation from the sample size, median, range and/or interquartile range. BMC Med Res Methodol 2014 Dec 19;14:135 [FREE Full text] [doi: 10.1186/1471-2288-14-135] [Medline: 25524443]

65. Al Helali AA, Saeed GA, Elholiby TI, Kukkady MA, Mazrouei SSA. Radiological and clinical improvement in a patient with COVID-19 pneumonia postconvalescent plasma transfusion: a case report. Radiol Case Rep 2020 Nov;15(11):2171-2174 [FREE Full text] [doi: 10.1016/j.radcr.2020.07.031] [Medline: $\underline{\text { 32901209] }}$

66. Anderson J, Schauer J, Bryant S, Graves C. The use of convalescent plasma therapy and remdesivir in the successful management of a critically ill obstetric patient with novel coronavirus 2019 infection: a case report. Case Rep Womens Health 2020 Jul;27:e00221 [FREE Full text] [doi: 10.1016/j.crwh.2020.e00221] [Medline: $\underline{32426243}$ ]

67. Bao Y, Lin SY, Cheng ZH, Xia J, Sun YP, Zhao Q, et al. Clinical features of COVID-19 in a young man with massive cerebral hemorrhage-case report. SN Compr Clin Med 2020 May 23:1-7 [FREE Full text] [doi: 10.1007/s42399-020-00315-y] [Medline: 32838132]

68. Çınar OE, Sayınalp B, Aladağ Karakulak E, Avşar Karataş A, Velet M, İnkaya A, et al. Convalescent (immune) plasma treatment in a myelodysplastic COVID-19 patient with disseminated tuberculosis. Transfus Apher Sci 2020 Oct;59(5):102821 [FREE Full text] [doi: 10.1016/j.transci.2020.102821] [Medline: 32487513]

69. Clark E, Guilpain P, Filip IL, Pansu N, Le Bihan C, Cartron G, et al. Convalescent plasma for persisting COVID-19 following therapeutic lymphocyte depletion: a report of rapid recovery. Br J Haematol 2020 Aug;190(3):e154-e156 [FREE Full text] [doi: 10.1111/bjh.16981] [Medline: $\underline{32593180]}$

70. Figlerowicz M, Mania A, Lubarski K, Lewandowska Z, Służewski W, Derwich K, et al. First case of convalescent plasma transfusion in a child with COVID-19-associated severe aplastic anemia. Transfus Apher Sci 2020 Oct;59(5):102866 [FREE Full text] [doi: $\underline{10.1016 / j . t r a n s c i .2020 .102866}$ ] [Medline: $\underline{\text { 32636116] }}$

71. Grisolia G, Franchini M, Glingani C, Inglese F, Garuti M, Beccaria M, et al. Convalescent plasma for coronavirus disease 2019 in pregnancy: a case report and review. Am J Obstet Gynecol MFM 2020 Aug;2(3):100174 [FREE Full text] [doi: 10.1016/j.ajogmf.2020.100174] [Medline: $\underline{32838270]}$

72. Hahn M, Condori MEH, Totland A, Kristoffersen EK, Hervig TA. A patient with severe COVID-19 treated with convalescent plasma. Tidsskr Nor Laegeforen 2020 Sep 08;140(12): 1 [FREE Full text] [doi: 10.4045/tidsskr.20.0501] [Medline: 32900176]

73. Hartman WR, Hess AS, Connor JP. Unusual cardiac presentation of COVID-19 and use of convalescent plasma. Case Rep Cardiol 2020;2020:8863195. [doi: $\underline{10.1155 / 2020 / 8863195]}$ [Medline: $\underline{33062340}$ ]

74. Im JH, Nahm CH, Baek JH, Kwon HY, Lee J. Convalescent plasma therapy in coronavirus disease 2019: a case report and suggestions to overcome obstacles. J Korean Med Sci 2020 Jul 06;35(26):e239 [FREE Full text] [doi: 10.3346/jkms.2020.35.e239] [Medline: 32627442]

75. Jafari R, Jonaidi-Jafari N, Dehghanpoor F, Saburi A. Convalescent plasma therapy in a pregnant COVID-19 patient with a dramatic clinical and imaging response: a case report. World J Radiol 2020 Jul 28;12(7):137-141 [FREE Full text] [doi: 10.4329/wjr.v12.i7.137] [Medline: 32850016]

76. Jiang J, Miao Y, Zhao Y, Lu X, Zhou P, Zhou X, et al. Convalescent plasma therapy: helpful treatment of COVID-19 in a kidney transplant recipient presenting with severe clinical manifestations and complex complications. Clin Transplant 2020 Sep;34(9):e14025 [FREE Full text] [doi: 10.1111/ctr.14025] [Medline: 32602952]

77. Karataş A, İnkaya A, Demiroğlu H, Aksu S, Haziyev T, Çınar OE, et al. Prolonged viral shedding in a lymphoma patient with COVID-19 infection receiving convalescent plasma. Transfus Apher Sci 2020 Oct;59(5):102871 [FREE Full text] [doi: 10.1016/j.transci.2020.102871] [Medline: 32694044]

78. Khan A, Ajmal Z, Raval M, Tobin E. Concurrent diagnosis of acute myeloid leukemia and COVID-19: a management challenge. Cureus 2020 Aug 09;12(8):e9629 [FREE Full text] [doi: 10.7759/cureus.9629] [Medline: $\underline{32923230]}$

79. Kong Y, Cai C, Ling L, Zeng L, Wu M, Wu Y, et al. Successful treatment of a centenarian with coronavirus disease 2019 (COVID-19) using convalescent plasma. Transfus Apher Sci 2020 Oct;59(5):102820 [FREE Full text] [doi: 10.1016/j.transci.2020.102820] [Medline: $\underline{\text { 32467007] }}$

80. Mira E, Yarce OA, Ortega C, Fernández S, Pascual NM, Gómez C, et al. Rapid recovery of a SARS-CoV-2-infected X-linked agammaglobulinemia patient after infusion of COVID-19 convalescent plasma. J Allergy Clin Immunol Pract 2020 Sep;8(8):2793-2795 [FREE Full text] [doi: 10.1016/j.jaip.2020.06.046] [Medline: 32652231 ]

81. Rodriguez Z, Shane A, Verkerke H, Lough C, Zimmerman M, Suthar M, et al. COVID-19 convalescent plasma clears SARS-CoV-2 refractory to remdesivir in an infant with congenital heart disease. Blood Adv 2020 Sep 22;4(18):4278-4281 [FREE Full text] [doi: 10.1182/bloodadvances.2020002507] [Medline: 32915971]

82. Soleimani Z, Soleimani A. ADRS due to COVID-19 in midterm pregnancy: successful management with plasma transfusion and corticosteroids. J Matern Fetal Neonatal Med 2020 Jul 26:1-4. [doi: 10.1080/14767058.2020.1797669] [Medline: $\underline{32715804]}$ 
83. Xu T, Lin B, Chen C, Liu L, Xue Y. Non-optimal effectiveness of convalescent plasma transfusion and hydroxychloroquine in treating COVID-19: a case report. Virol J 2020 Jun 19;17(1):80 [FREE Full text] [doi: 10.1186/s12985-020-01354-6] [Medline: $\underline{32560646]}$

84. Zhang L, Pang R, Xue X, Bao J, Ye S, Dai Y, et al. Anti-SARS-CoV-2 virus antibody levels in convalescent plasma of six donors who have recovered from COVID-19. Aging (Albany NY) 2020 Apr 22;12(8):6536-6542 [REEE Full text] [doi: 10.18632/aging.103102] [Medline: 32320384]

85. Ahn JY, Sohn Y, Lee SH, Cho Y, Hyun JH, Baek YJ, et al. Use of convalescent plasma therapy in two COVID-19 patients with acute respiratory distress syndrome in Korea. J Korean Med Sci 2020 Apr 13;35(14):e149 [FREE Full text] [doi: 10.3346/jkms.2020.35.e149] [Medline: 32281317]

86. Abdullah H, Hama-Ali H, Ahmed S, Ali K, Karadakhy K, Mahmood S, et al. A severe refractory COVID-19 patient responding to convalescent plasma; a case series. Ann Med Surg (Lond) 2020 Aug;56:125-127 [FREE Full text] [doi: 10.1016/j.amsu.2020.06.018] [Medline: 32637086]

87. Bradfute S, Hurwitz I, Yingling A, Ye C, Cheng Q, Noonan T, et al. Severe acute respiratory syndrome coronavirus 2 neutralizing antibody titers in convalescent plasma and recipients in New Mexico: an open treatment study in patients with coronavirus disease 2019. J Infect Dis 2020 Oct 13;222(10):1620-1628 [FREE Full text] [doi: 10.1093/infdis/jiaa505] [Medline: 32779705]

88. Diorio C, Anderson EM, McNerney KO, Goodwin EC, Chase JC, Bolton MJ, et al. Convalescent plasma for pediatric patients with SARS-CoV-2-associated acute respiratory distress syndrome. Pediatr Blood Cancer 2020 Nov;67(11):e28693. [doi: 10.1002/pbc.28693] [Medline: 32885904]

89. Enzmann MO, Erickson MP, Grindeland CJ, Lopez SMC, Hoover SE, Leedahl DD. Treatment and preliminary outcomes of 150 acute care patients with COVID-19 in a rural health system in the Dakotas. Epidemiol Infect 2020 Jun 22;148:e124 [FREE Full text] [doi: 10.1017/S0950268820001351] [Medline: 32605683]

90. Erkurt MA, Sarici A, Berber İ, Kuku İ, Kaya E, Özgül M. Life-saving effect of convalescent plasma treatment in covid-19 disease: clinical trial from eastern Anatolia. Transfus Apher Sci 2020 Oct;59(5):102867 [FREE Full text] [doi: 10.1016/j.transci.2020.102867] [Medline: 32620409]

91. Gemici A, Bilgen H, Erdoğan C, Kansu A, Olmuşçelik O, Beköz HS, et al. A single center cohort of 40 severe COVID-19 patients who were treated with convalescent plasma. Turk J Med Sci 2020 Dec 17;50(8):1781-1785. [doi: 10.3906/sag-2009-77] [Medline: 33078604]

92. Ibrahim D, Dulipsingh L, Zapatka L, Eadie R, Crowell R, Williams K, et al. Factors associated with good patient outcomes following convalescent plasma in COVID-19: a prospective phase II clinical trial. Infect Dis Ther 2020 Sep 20:1-14. [doi: 10.1007/s40121-020-00341-2] [Medline: 32983830]

93. Bobek I, Gopcsa L, Réti M, Bekő G, Hancz L, Lakatos B, et al. Successful administration of convalescent plasma in critically ill COVID-19 patients in Hungary: the first two cases. Orv Hetil 2020 Jul;161(27):1111-1121. [doi: 10.1556/650.2020.31901] [Medline: 32564002]

94. Jin H, Reed JC, Liu ST, Ho H, Lopes JP, Ramsey NB, Mount Sinai Health System Convalescent Plasma Team. Three patients with X-linked agammaglobulinemia hospitalized for COVID-19 improved with convalescent plasma. J Allergy Clin Immunol Pract 2020;8(10):3594-3596.e3 [FREE Full text] [doi: 10.1016/j.jaip.2020.08.059] [Medline: 32947026]

95. Joyner M, Wright R, Fairweather D, Senefeld J, Bruno K, Klassen S, et al. Early safety indicators of COVID-19 convalescent plasma in 5000 patients. J Clin Invest 2020 Sep 01;130(9):4791-4797. [doi: 10.1172/JCI140200] [Medline: $\underline{32525844]}$

96. Joyner M, Bruno K, Klassen S, Kunze K, Johnson P, Lesser E, et al. Safety update: COVID-19 convalescent plasma in 20,000 hospitalized patients. Mayo Clin Proc 2020 Sep;95(9):1888-1897 [FREE Full text] [doi: 10.1016/j.mayocp.2020.06.028] [Medline: 32861333]

97. Joyner M, Senefeld J, Klassen S, Mills J, Johnson P, Theel E, et al. Effect of convalescent plasma on mortality among hospitalized patients with COVID-19: initial three-month experience. medRxiv. Preprint posted online on August 12, 2020. [doi: 10.1101/2020.08.12.20169359] [Medline: 32817978]

98. Liu M, Chen Z, Dai M, Yang J, Chen X, Chen D, et al. Lessons learned from early compassionate use of convalescent plasma on critically ill patients with Covid-19. Transfusion 2020 Oct;60(10):2210-2216 [FREE Full text] [doi: 10.1111/trf.15975] [Medline: 32770691]

99. Maor Y, Cohen D, Paran N, Israely T, Ezra V, Axelrod O, et al. Compassionate use of convalescent plasma for treatment of moderate and severe pneumonia in COVID-19 patients and association with IgG antibody levels in donated plasma. EClinicalMedicine 2020 Sep;26:100525. [doi: 10.1016/j.eclinm.2020.100525] [Medline: 32923991]

100. Naeem S, Gohh R, Bayliss G, Cosgrove C, Farmakiotis D, Merhi B, et al. Successful recovery from COVID-19 in three kidney transplant recipients who received convalescent plasma therapy. Transpl Infect Dis 2021 Feb;23(1):e13451 [FREE Full text] [doi: 10.1111/tid.13451] [Medline: 32815238]

101. Olivares-Gazca JC, Priesca-Marín JM, Ojeda-Laguna M, Garces-Eisele J, Soto-Olvera S, Palacios-Alonso A, et al. Infusion of convalescent plasma is associated with clinical improvement in critically ill patients with COVID-19: a pilot study. Rev Invest Clin 2020;72(3):159-164. [doi: 10.24875/RIC.20000237] [Medline: 32584322] 
102. Pal P, Ibrahim M, Niu A, Zwezdaryk KJ, Tatje E, Robinson WR, et al. Safety and efficacy of COVID-19 convalescent plasma in severe pulmonary disease: a report of 17 patients. Transfus Med 2020 Oct 19:1. [doi: 10.1111/tme.12729] [Medline: $\underline{33073895]}$

103. Rahman F, Liu STH, Taimur S, Jacobs S, Sullivan T, Dunn D, et al. Treatment with convalescent plasma in solid organ transplant recipients with COVID-19: experience at large transplant center in New York City. Clin Transplant 2020 Dec;34(12):e14089. [doi: 10.1111/ctr.14089] [Medline: $\underline{\text { 32918761] }}$

104. Salazar E, Perez KK, Ashraf M, Chen J, Castillo B, Christensen PA, et al. Treatment of coronavirus disease 2019 (COVID-19) patients with convalescent plasma. Am J Pathol 2020 Aug;190(8):1680-1690 [FREE Full text] [doi: 10.1016/j.ajpath.2020.05.014] [Medline: 32473109]

105. Shen C, Wang Z, Zhao F, Yang Y, Li J, Yuan J, et al. Treatment of 5 critically ill patients with COVID-19 with convalescent plasma. JAMA 2020 Apr 28;323(16):1582-1589 [FREE Full text] [doi: 10.1001/jama.2020.4783] [Medline: $\underline{32219428]}$

106. Tremblay D, Seah C, Schneider T, Bhalla S, Feld J, Naymagon L, Mount Sinai Health System Convalescent Plasma Team. Convalescent plasma for the treatment of severe COVID-19 infection in cancer patients. Cancer Med 2020 Nov;9(22):8571-8578. [doi: 10.1002/cam4.3457] [Medline: 32945149]

107. Wei B, Hang X, Xie Y, Zhang Y, Wang J, Cao X, et al. Long-term positive severe acute respiratory syndrome coronavirus 2 ribonucleic acid and therapeutic effect of antivirals in patients with coronavirus disease: case reports. Rev Soc Bras Med Trop 2020;53:e20200372 [FREE Full text] [doi: 10.1590/0037-8682-0372-2020] [Medline: 32696811]

108. Wang M, Yang X, Yang F, Zhu X, Sun Z, Bao P, et al. Convalescent plasma therapy in critically ill coronavirus disease 2019 patients with persistently positive nucleic acid test, case series report. Medicine (Baltimore) 2020 Sep 04;99(36):e21596. [doi: 10.1097/MD.0000000000021596] [Medline: $\underline{\text { 32898996] }}$

109. Wu Y, Hong K, Ruan L, Yang X, Zhang J, Xu J, et al. Patients with prolonged positivity of SARS-CoV-2 RNA benefit from convalescent plasma therapy: a retrospective study. Virol Sin 2020 Dec;35(6):768-775 [FREE Full text] [doi: 10.1007/s12250-020-00281-8] [Medline: $\underline{32865701]}$

110. Xi A, Zhuo M, Dai J, Ding Y, Ma X, Ma X, et al. Epidemiological and clinical characteristics of discharged patients infected with SARS-CoV-2 on the Qinghai Plateau. J Med Virol 2020 Nov;92(11):2528-2535 [FREE Full text] [doi: 10.1002/jmv.26032] [Medline: 32437017]

111. Ye M, Fu D, Ren Y, Wang F, Wang D, Zhang F, et al. Treatment with convalescent plasma for COVID-19 patients in Wuhan, China. J Med Virol 2020 Oct;92(10):1890-1901 [FREE Full text] [doi: 10.1002/jmv.25882] [Medline: 32293713]

112. Zhang B, Liu S, Tan T, Huang W, Dong Y, Chen L, et al. Treatment with convalescent plasma for critically ill patients with severe acute respiratory syndrome coronavirus 2 infection. Chest 2020 Jul;158(1):e9-e13 [FREE Full text] [doi: 10.1016/j.chest.2020.03.039] [Medline: 32243945]

113. Zeng H, Wang D, Nie J, Liang H, Gu J, Zhao A, et al. The efficacy assessment of convalescent plasma therapy for COVID-19 patients: a multi-center case series. Signal Transduct Target Ther 2020 Oct 06;5(1):219. [doi: 10.1038/s41392-020-00329-x] [Medline: 33024082]

114. Abolghasemi H, Eshghi P, Cheraghali A, Imani Fooladi AA, Bolouki Moghaddam F, Imanizadeh S, et al. Clinical efficacy of convalescent plasma for treatment of COVID-19 infections: results of a multicenter clinical study. Transfus Apher Sci 2020 Oct;59(5):102875 [FREE Full text] [doi: 10.1016/j.transci.2020.102875] [Medline: 32694043]

115. Duan K, Liu B, Li C, Zhang H, Yu T, Qu J, et al. Effectiveness of convalescent plasma therapy in severe COVID-19 patients. Proc Natl Acad Sci U S A 2020 Apr 28;117(17):9490-9496 [FREE Full text] [doi: 10.1073/pnas.2004168117] [Medline: 32253318]

116. Hegerova L, Gooley T, Sweerus K, Maree C, Bailey N, Bailey M, et al. Use of convalescent plasma in hospitalized patients with COVID-19: case series. Blood 2020 Aug 06;136(6):759-762 [FREE Full text] [doi: 10.1182/blood.2020006964] [Medline: 32559767]

117. Liu STH, Lin H, Baine I, Wajnberg A, Gumprecht JP, Rahman F, et al. Convalescent plasma treatment of severe COVID-19: a propensity score-matched control study. Nat Med 2020 Nov;26(11):1708-1713. [doi: 10.1038/s41591-020-1088-9] [Medline: 32934372]

118. Perotti C, Baldanti F, Bruno R, Del Fante C, Seminari E, Casari S, Covid-Plasma Task Force. Mortality reduction in 46 severe Covid-19 patients treated with hyperimmune plasma. A proof of concept single arm multicenter trial. Haematologica 2020 Dec 01;105(12):2834-2840. [doi: 10.3324/haematol.2020.261784] [Medline: 33256382]

119. Rasheed A, Fatak D, Hashim H, Maulood M, Kabah K, Almusawi Y, et al. The therapeutic potential of convalescent plasma therapy on treating critically-ill COVID-19 patients residing in respiratory care units in hospitals in Baghdad, Iraq. Infez Med 2020 Sep 01;28(3):357-366 [FREE Full text] [Medline: 32920571]

120. Rogers R, Shehadeh F, Mylona E, Rich J, Neill M, Touzard-Romo F, et al. Convalescent plasma for patients with severe COVID-19: a matched cohort study. Clin Infect Dis 2020 Oct 10:ciaa1548 [FREE Full text] [doi: 10.1093/cid/ciaa1548] [Medline: 33038227]

121. Salazar E, Christensen PA, Graviss EA, Nguyen DT, Castillo B, Chen J, et al. Treatment of coronavirus disease 2019 patients with convalescent plasma reveals a signal of significantly decreased mortality. Am J Pathol 2020 Nov;190(11):2290-2303 [FREE Full text] [doi: 10.1016/j.ajpath.2020.08.001] [Medline: 32795424] 
122. Xia X, Li K, Wu L, Wang Z, Zhu M, Huang B, et al. Improved clinical symptoms and mortality among patients with severe or critical COVID-19 after convalescent plasma transfusion. Blood 2020 Aug 06;136(6):755-759 [FREE Full text] [doi: 10.1182/blood.2020007079] [Medline: 32573724]

123. Xiao K, Lin Y, Fan Z, Wen Y, Huang H, Wang M, et al. Effect of transfusion convalescent recovery plasma in patients with coronavirus disease 2019. Zhong Nan Da Xue Xue Bao Yi Xue Ban 2020 May 28;45(5):565-570 [FREE Full text] [doi: 10.11817/j.issn.1672-7347.2020.200318] [Medline: $\underline{32879108]}$

124. Zeng Q, Yu Z, Gou J, Li G, Ma S, Zhang G, et al. Effect of convalescent plasma therapy on viral shedding and survival in patients with coronavirus disease 2019. J Infect Dis 2020 Jun 16;222(1):38-43 [FREE Full text] [doi: $\underline{10.1093 / \text { infdis/jiaa228] }}$ [Medline: 32348485]

125. Gharbharan A, Jordans CCE, Geurtsvankessel C, den Hollander JG, Karim F, Mollema FPN, et al. Convalescent plasma for COVID-19. A randomized clinical trial. medRxiv. Preprint posted online on July 3, 2020. [doi: $\underline{10.1101 / 2020.07 .01 .20139857]}$

126. Li L, Zhang W, Hu Y, Tong X, Zheng S, Yang J, et al. Effect of convalescent plasma therapy on time to clinical improvement in patients with severe and life-threatening COVID-19: a randomized clinical trial. JAMA 2020 Aug 04;324(5):460-470 [FREE Full text] [doi: 10.1001/jama.2020.10044] [Medline: 32492084]

127. Alghamdi AN, Abdel-Moneim AS. Convalescent plasma: a potential life-saving therapy for coronavirus disease 2019 (COVID-19). Front Public Health 2020;8:437. [doi: 10.3389/fpubh.2020.00437] [Medline: 32903641]

128. Alzoughool F, Alanagreh L. Coronavirus drugs: using plasma from recovered patients as a treatment for COVID-19. Int J Risk Saf Med 2020;31(2):47-51 [FREE Full text] [doi: 10.3233/JRS-201017] [Medline: 32310190]

129. Borlongan MC, Borlongan MC, Sanberg PR. The disillusioned comfort with COVID-19 and the potential of convalescent plasma and cell therapy. Cell Transplant 2020;29:963689720940719 [FREE Full text] [doi: 10.1177/0963689720940719] [Medline: 32841042]

130. Cantore I, Valente P. Convalescent plasma from COVID 19 patients enhances intensive care unit survival rate. A preliminary report. Transfus Apher Sci 2020 Oct;59(5):102848 [FREE Full text] [doi: 10.1016/j.transci.2020.102848] [Medline: 32888822]

131. Casadevall A, Joyner MJ, Pirofski L. A randomized trial of convalescent plasma for COVID-19-potentially hopeful signals. JAMA 2020 Aug 04;324(5):455-457. [doi: 10.1001/jama.2020.10218] [Medline: 32492105]

132. Cheraghali AM, Abolghasemi H, Eshghi P. Management of COVID-19 virus infection by convalescent plasma. Iran J Allergy Asthma Immunol 2020 May 17;19(S1):3-6 [FREE Full text] [doi: 10.18502/ijaai.v19i(s1.r1).2847] [Medline: 32534509]

133. Gazzaruso C, Valenti C, Coppola A, Gallotti P. Impact of convalescent and nonimmune plasma on mortality of patients with COVID-19: a potential role for antithrombin. Clin Microbiol Infect 2020 Sep 09:S1198-743X(20)30536-X [FREE Full text] [doi: 10.1016/j.cmi.2020.09.007] [Medline: $\underline{\text { 32919071] }}$

134. Farhat RM, Mousa MA, Daas EJ, Glassberg MK. Treatment of COVID-19: perspective on convalescent plasma transfusion. Front Med (Lausanne) 2020;7:435. [doi: 10.3389/fmed.2020.00435] [Medline: $\underline{32850916}$ ]

135. Focosi D, Tuccori M, Antonelli G, Maggi F. What is the optimal usage of coronavirus disease 2019 convalescent plasma donations? Clin Microbiol Infect 2021 Feb;27(2):163-165 [FREE Full text] [doi: 10.1016/j.cmi.2020.09.036] [Medline: 33007479]

136. Franchini M. Why should we use convalescent plasma for COVID-19? Eur J Intern Med 2020 Jul;77:150-151 [FREE Full text] [doi: 10.1016/j.ejim.2020.05.019] [Medline: 32425365]

137. Franchini M, Marano G, Velati C, Pati I, Pupella S, Liumbruno GM. Regarding international forum on hospital transfusion services' response to COVID-19. Vox Sang 2020 Nov;115(8):827 [FREE Full text] [doi: 10.1111/vox.12967] [Medline: 32516835]

138. Franchini M, Del Fante C, Klersy C, Glingani C, Percivalle E, Baldanti F, et al. Challenges in the production of convalescent hyperimmune plasma in the age of COVID-19. Semin Thromb Hemost 2020 Oct;46(7):804-806 [FREE Full text] [doi: 10.1055/s-0040-1713433] [Medline: 32512588]

139. Franchini M, Marano G, Velati C, Pati I, Pupella S, Maria Liumbruno G. Operational protocol for donation of anti-COVID-19 convalescent plasma in Italy. Vox Sang 2021 Jan;116(1):136-137 [FREE Full text] [doi: 10.1111/vox.12940] [Medline: 32324899]

140. Islam A, Rafiq S, Karim S, Laher I, Rashid H. Convalescent plasma therapy in the treatment of COVID-19: practical considerations: correspondence. Int J Surg 2020 Jul;79:204-205 [FREE Full text] [doi: 10.1016/j.ijsu.2020.05.079] [Medline: 32502707]

141. Kesici S, Yavuz S, Bayrakci B. Get rid of the bad first: therapeutic plasma exchange with convalescent plasma for severe COVID-19. Proc Natl Acad Sci U S A 2020 Jun 09;117(23):12526-12527 [FREE Full text] [doi: 10.1073/pnas.2006691117] [Medline: 32398378]

142. Knudson CM, Jackson JB. COVID-19 convalescent plasma: phase 2. Transfusion 2020 Jun;60(6):1332-1333 [FREE Full text] [doi: 10.1111/trf.15842] [Medline: $\underline{32374890]}$

143. Kumar S, Sharma V, Priya K. Battle against COVID-19: efficacy of convalescent plasma as an emergency therapy. Am J Emerg Med 2021 Mar;41:244-246 [FREE Full text] [doi: 10.1016/j.ajem.2020.05.101] [Medline: 32505474] 
144. McAllister F, Mantegazza A, Garzón F, Rotbaum V, Remondino G, Vazquez Larsson M, et al. [Use of convalescent plasma for COVID-19 treatment. History and evidence]. Medicina (B Aires) 2020;80 Suppl 3:82-86 [FREE Full text] [Medline: 32658853]

145. Nnaji CA, Iwu CJ, Ndwandwe DE, Jordan P, Wiysonge CS. Convalescent plasma or hyperimmune immunoglobulin for people with COVID-19. S Afr Med J 2020 Jul 16;110(8):759-760 [FREE Full text] [Medline: 32880303]

146. Pau AK, Aberg J, Baker J, Belperio PS, Coopersmith C, Crew P, et al. Convalescent plasma for the treatment of COVID-19: perspectives of the National Institutes of Health COVID-19 Treatment Guidelines Panel. Ann Intern Med 2021 Jan;174(1):93-95 [FREE Full text] [doi: 10.7326/M20-6448] [Medline: 32976026]

147. Rabelo-da-Ponte F, Silvello D, Scherer J, Ayala A, Klamt F. Convalescent plasma therapy in patients with severe or life-threatening COVID-19: a metadata analysis. J Infect Dis 2020 Oct 01;222(9):1575-1578 [FREE Full text] [doi: 10.1093/infdis/jiaa509] [Medline: 32777038]

148. Roback JD, Guarner J. Convalescent plasma to treat COVID-19: possibilities and challenges. JAMA 2020 Apr 28;323(16):1561-1562. [doi: 10.1001/jama.2020.4940] [Medline: 32219429]

149. Roberts DJ, Miflin G, Estcourt L. Convalescent plasma for COVID-19: back to the future. Transfus Med 2020 Jun;30(3):174-176 [FREE Full text] [doi: 10.1111/tme.12700] [Medline: 32447783]

150. Sabando Vélez BE, Plaza Meneses C, Felix M, Vanegas E, Mata VL, Romero Castillo H, et al. A practical approach for the compassionate use of convalescent plasma in patients with severe COVID-19 in developing countries. J Infect Dev Ctries 2020 Jul 31;14(7):737-741 [FREE Full text] [doi: 10.3855/jidc.12827] [Medline: $\underline{\text { 32794463] }}$

151. Sahu KK, Jindal V, Siddiqui AD, Cerny J, Gerber JM. Convalescent plasma therapy: a passive therapy for an aggressive COVID-19. J Med Virol 2020 Nov;92(11):2251-2253 [FREE Full text] [doi: 10.1002/jmv.26047] [Medline: 32437024$]$

152. Sheikh S, Baig MA. Convalescent plasma: promise for COVID-19 pandemic. J Coll Physicians Surg Pak 2020 Jun;30(6):88. [doi: 10.29271/jcpsp.2020.Supp1.S88] [Medline: $\underline{32723468]}$

153. Syal K. COVID-19: herd immunity and convalescent plasma transfer therapy. J Med Virol 2020 Sep;92(9):1380-1382 [FREE Full text] [doi: 10.1002/jmv.25870] [Medline: $\underline{\text { 32281679] }}$

154. Teixeira da Silva JA. Convalescent plasma: a possible treatment of COVID-19 in India. Med J Armed Forces India 2020 Apr;76(2):236-237 [FREE Full text] [doi: 10.1016/j.mjafi.2020.04.006] [Medline: 32296259]

155. The Lancet Haematology. The resurgence of convalescent plasma therapy. Lancet Haematol 2020 May;7(5):e353 [FREE Full text] [doi: 10.1016/S2352-3026(20)30117-4] [Medline: 32359447]

156. Tonn T, Corman VM, Johnsen M, Richter A, Rodionov RN, Drosten C, et al. Stability and neutralising capacity of SARS-CoV-2-specific antibodies in convalescent plasma. Lancet Microbe 2020 Jun;1(2):e63 [FREE Full text] [doi: 10.1016/S2666-5247(20)30037-9] [Medline: 32835332]

157. Wong H, Lee C. Pivotal role of convalescent plasma in managing emerging infectious diseases. Vox Sang 2020 Oct;115(7):545-547 [FREE Full text] [doi: 10.1111/vox.12927] [Medline: 32240549]

158. Yoo J. Convalescent plasma therapy for corona virus disease 2019: a long way to go but worth trying. J Korean Med Sci 2020 Apr 13;35(14):e150 [FREE Full text] [doi: 10.3346/jkms.2020.35.e150] [Medline: 32281318]

159. Zhao Q, He Y. Challenges of convalescent plasma therapy on COVID-19. J Clin Virol 2020 Jun;127:104358 [FREE Full text] [doi: 10.1016/j.jcv.2020.104358] [Medline: $\underline{32305026]}$

160. Zhu M, Hu K, Zhu Z. Use of convalescent plasma in COVID-19 patients in China. Transfus Clin Biol 2020 Aug;27(3):168-169 [FREE Full text] [doi: 10.1016/j.tracli.2020.05.001] [Medline: 32425645]

161. Tamburello A, Marando M. Immunoglobulins or convalescent plasma to tackle COVID-19: buying time to save lives current situation and perspectives. Swiss Med Wkly 2020 Apr 20;150:w20264. [doi: 10.4414/smw.2020.20264] [Medline: $\underline{32343358]}$

162. Begum F, Ray U. Polymonoclonal (not polyclonal) antibodies derived from convalescent human B cell hybridomas might be a better therapeutic option than single target monoclonal antibodies. ACS Pharmacol Transl Sci 2020 Aug 14;3(4):786-787. [doi: 10.1021/acsptsci.0c00084] [Medline: 32832877]

163. Bloch E. Convalescent plasma to treat COVID-19. Blood 2020 Aug 06;136(6):654-655 [FREE Full text] [doi: 10.1182/blood.2020007714] [Medline: 32761219]

164. Brown B. Response Letter: treatment for emerging viruses: convalescent plasma and COVID-19. Transfus Apher Sci 2021 Feb;60(1):102929 [FREE Full text] [doi: 10.1016/j.transci.2020.102929] [Medline: 32933845]

165. Casadevall A, Joyner M, Pirofski LA. Implications of COVI-19 antibody dynamics for immunity and convalescent plasma therapy. Clin Infect Dis 2020 Aug 17:ciaa1213 [FREE Full text] [doi: 10.1093/cid/ciaa1213] [Medline: 32805024$]$

166. Casadevall A, Joyner M, Pirofski L. SARS-CoV-2 viral load and antibody responses: the case for convalescent plasma therapy. J Clin Invest 2020 Oct 01;130(10):5112-5114. [doi: 10.1172/JCI139760] [Medline: $\underline{\text { 32634126] }}$

167. Cunningham AC, Goh HP, Koh D. Treatment of COVID-19: old tricks for new challenges. Crit Care 2020 Mar 16;24(1):91 [FREE Full text] [doi: 10.1186/s13054-020-2818-6] [Medline: 32178711]

168. Dhanasekaran S, Vajravelu LK, Venkatesalu V. Risk-benefit analysis on the clinical significance of convalescent plasma therapy in the management of COVID-19. Postgrad Med J 2020 Aug 17:1. [doi: 10.1136/postgradmedj-2020-138056] [Medline: $\underline{\text { 32817576] }}$ 
169. Dzik S. COVID-19 convalescent plasma: now is the time for better science. Transfus Med Rev 2020 Jul;34(3):141-144 [FREE Full text] [doi: 10.1016/j.tmrv.2020.04.002] [Medline: $\underline{32359789}$ ]

170. Estcourt LJ, Roberts DJ. Convalescent plasma for covid-19. BMJ 2020 Sep 15;370:m3516. [doi: 10.1136/bmj.m3516] [Medline: 32933945]

171. Farrugia A. Plasma from donors convalescent from SARS-CoV-2 infection-A matter of priorities. Transfus Clin Biol 2020 Aug;27(3):167-168 [FREE Full text] [doi: 10.1016/j.tracli.2020.05.002] [Medline: 32563550]

172. Fleming AB, Raabe V. Current studies of convalescent plasma therapy for COVID-19 may underestimate risk of antibody-dependent enhancement. J Clin Virol 2020 Jun;127:104388 [FREE Full text] [doi: 10.1016/j.jcv.2020.104388] [Medline: $\underline{\text { 32361326] }}$

173. Focosi D. Anti-A isohaemagglutinin titres and SARS-CoV-2 neutralization: implications for children and convalescent plasma selection. Br J Haematol 2020 Aug;190(3):e148-e150 [FREE Full text] [doi: 10.1111/bjh.16932] [Medline: 32516462]

174. Garraud O. Passive immunotherapy with convalescent plasma against COVID-19? What about the evidence base and clinical trials? Transfus Apher Sci 2020 Aug;59(4):102858 [FREE Full text] [doi: 10.1016/j.transci.2020.102858] [Medline: 32631501]

175. Gniadek TJ, Donnersberger D. COVID-19 convalescent plasma donor recruitment: beware the Faustian bargains. Transfusion 2020 Jul;60(7):1643-1644 [FREE Full text] [doi: 10.1111/trf.15871] [Medline: 32428966]

176. Han G, Zhou Y. Thinking more about therapy with convalescent plasma for COVID-19 patients. Hum Vaccin Immunother 2020 Nov 01;16(11):2601-2603. [doi: 10.1080/21645515.2020.1787073] [Medline: $\underline{32643512}$ ]

177. Langhi DM, Santis GCD, Bordin JO. COVID-19 convalescent plasma transfusion. Hematol Transfus Cell Ther 2020;42(2):113-115 [FREE Full text] [doi: 10.1016/j.htct.2020.04.003] [Medline: $\underline{\text { 32313872] }}$

178. Lanza F, Seghatchian J. Reflection on passive immunotherapy in those who need most: some novel strategic arguments for obtaining safer therapeutic plasma or autologous antibodies from recovered COVID-19 infected patients. Br J Haematol $2020 \mathrm{Jul}$;190(1):e27-e29 [FREE Full text] [doi: 10.1111/bjh.16814] [Medline: $\underline{32407543}$ ]

179. Mahase E. Covid-19: US approves emergency use of convalescent plasma despite warnings over lack of evidence. BMJ 2020 Aug 25;370:m3327. [doi: 10.1136/bmj.m3327] [Medline: 32843328]

180. Mahase E. Covid-19: US FDA fires spokesperson over misleading claims about convalescent plasma. BMJ 2020 Sep 02;370:m3400. [doi: 10.1136/bmj.m3400] [Medline: $\underline{32878748]}$

181. Adiwinata Pawitan J. Convalescent plasma for COVID-19 considerations. Transfus Apher Sci 2021 Feb;60(1):102927 [FREE Full text] [doi: 10.1016/j.transci.2020.102927] [Medline: 32878733]

182. Prajapati S. Isopathic remedy prepared from convalescent plasma as a therapeutic option for COVID-19? Homeopathy 2020 Aug;109(3):184-185. [doi: 10.1055/s-0040-1714061] [Medline: 32645727]

183. Saverino D. Hyper-immune/convalescent plasma: an old option and a valid strategy for treatment of COVID-19? Minerva Med 2020 Aug;111(4):362-364 [FREE Full text] [doi: 10.23736/S0026-4806.20.06616-1] [Medline: 32407051]

184. Stevens MP, Patel PK, Nori P. Antimicrobial stewardship programs and convalescent plasma for COVID-19: a new paradigm for preauthorization? Infect Control Hosp Epidemiol 2020 Sep 09:1-2 [FREE Full text] [doi: 10.1017/ice.2020.459] [Medline: 32900407]

185. Tedder RS, Semple MG. Appropriate selection of convalescent plasma donors for COVID-19. Lancet Infect Dis 2021 Feb;21(2):168-169 [FREE Full text] [doi: 10.1016/S1473-3099(20)30470-9] [Medline: $\underline{32553190]}$

186. Van den Berg K, Vermeulen M, Glatt T, Wasserman S, Barrett C, Peter J, et al. COVID-19: convalescent plasma as a potential therapy. S Afr Med J 2020 Jun 04;110(7):562-563. [Medline: 32880317]

187. Verkerke HP, Maier CL. Towards characterized convalescent plasma for COVID-19: the dose matters. EClinicalMedicine 2020 Sep;26:100545 [FREE Full text] [doi: 10.1016/j.eclinm.2020.100545] [Medline: 32984783]

188. Xi Y. Convalescent plasma therapy for COVID-19: a tried-and-true old strategy? Signal Transduct Target Ther 2020 Sep 15;5(1):203. [doi: 10.1038/s41392-020-00310-8] [Medline: 32934211]

189. Zeng F, Chen X, Deng G. Convalescent plasma for patients with COVID-19. Proc Natl Acad Sci U S A 2020 Jun 09;117(23):12528 [FREE Full text] [doi: 10.1073/pnas.2006961117] [Medline: 32398379]

190. Zylberman V, Sanguineti S, Pontoriero A, Higa S, Cerutti M, Morrone Seijo SM, et al. Development of a hyperimmune equine serum therapy for COVID-19 in Argentina. Medicina (B Aires) 2020;80 Suppl 3:1-6 [FREE Full text] [Medline: 32658841]

191. Caccamo N, Sullivan LC, Brooks AG, Dieli F. Harnessing HLA-E-restricted CD8 T lymphocytes for adoptive cell therapy of patients with severe COVID-19. Br J Haematol 2020 Aug;190(4):e185-e187 [FREE Full text] [doi: 10.1111/bjh.16895] [Medline: 32480418]

192. Ferreira LMR, Mostajo-Radji MA. Plasma-based COVID-19 treatments in low- and middle-income nations pose a high risk of an HIV epidemic. NPJ Vaccines 2020 Jul 06;5(1):58. [doi: 10.1038/s41541-020-0209-2] [Medline: $\underline{33580058]}$

193. Joob BV, Wiwanitkit V. Convalescent plasma and covid-19 treatment. Minerva Med 2020 Jun 12:1 [FREE Full text] [doi: 10.23736/S0026-4806.20.06670-7] [Medline: $\underline{\text { 32538591] }}$

194. Sanfilippo F, La Rosa V, Oliveri F, Astuto M. Convalescent plasma for COVID-19: the risk of pulmonary embolism should not be underestimated!. Crit Care 2020 Aug 28;24(1):531 [FREE Full text] [doi: 10.1186/s13054-020-03236-3] [Medline: $\underline{32859242]}$ 
195. Sanfilippo F, La Rosa V, Oliveri F, Astuto M. COVID-19, hypercoagulability, and cautiousness with convalescent plasma. Am J Respir Crit Care Med 2021 Jan 15;203(2):257-258 [FREE Full text] [doi: 10.1164/rccm.202008-3139LE] [Medline: $\underline{33085908]}$

196. Wiwanitkit V. Convalescent plasma therapy in the treatment of COVID-19: some considerations: correspondence. Int J Surg 2020 Aug;80:26 [FREE Full text] [doi: 10.1016/j.ijsu.2020.06.029] [Medline: 32585194]

197. Barone PR, DeSimone RA. Convalescent plasma to treat coronavirus disease 2019 (COVID-19): considerations for clinical trial design. Transfusion 2020 Jun;60(6):1123-1127 [FREE Full text] [doi: 10.1111/trf.15843] [Medline: 32374891]

198. Majbour NO, El-Agnaf O. Plasma-derived therapy: can the survivors of COVID-19 help the defenseless? Diagnosis (Berl) 2020 Nov 18;7(4):373-376. [doi: 10.1515/dx-2020-0053] [Medline: $\underline{32692700]}$

199. Brown BL, McCullough J. Treatment for emerging viruses: convalescent plasma and COVID-19. Transfus Apher Sci 2020 Jun;59(3):102790 [FREE Full text] [doi: 10.1016/j.transci.2020.102790] [Medline: 32345485]

200. Cao H, Shi Y. Convalescent plasma: possible therapy for novel coronavirus disease 2019. Transfusion 2020 May;60(5):1078-1083 [FREE Full text] [doi: 10.1111/trf.15797] [Medline: 32359090]

201. Zheng K, Liao G, Lalu MM, Tinmouth A, Fergusson DA, Allan DS. A scoping review of registered clinical trials of convalescent plasma for COVID-19 and a Framework for Accelerated Synthesis of Trial Evidence (FAST Evidence). Transfus Med Rev 2020 Jul;34(3):158-164 [FREE Full text] [doi: 10.1016/j.tmrv.2020.06.005] [Medline: 32771272]

202. de Alwis R, Chen S, Gan ES, Ooi EE. Impact of immune enhancement on Covid-19 polyclonal hyperimmune globulin therapy and vaccine development. EBioMedicine 2020 May;55:102768 [FREE Full text] [doi: 10.1016/j.ebiom.2020.102768] [Medline: 32344202]

203. Fischer JC, Zänker K, van Griensven M, Schneider M, Kindgen-Milles D, Knoefel WT, et al. The role of passive immunization in the age of SARS-CoV-2: an update. Eur J Med Res 2020 May 13;25(1):16 [FREE Full text] [doi: 10.1186/s40001-020-00414-5] [Medline: 32404189]

204. Mucha SR, Quraishy N. Convalescent plasma for COVID-19: promising, not proven. Cleve Clin J Med 2020 Nov 02;87(11):664-670 [FREE Full text] [doi: 10.3949/ccjm.87a.ccc056] [Medline: 32759176]

205. Chai K, Valk S, Piechotta V, Kimber C, Monsef I, Doree C, et al. Convalescent plasma or hyperimmune immunoglobulin for people with COVID-19: a living systematic review. Cochrane Database Syst Rev 2020 Oct 12;10:CD013600. [doi: 10.1002/14651858.CD013600.pub3] [Medline: 33044747]

206. Devasenapathy N, Ye Z, Loeb M, Fang F, Najafabadi BT, Xiao Y, et al. Efficacy and safety of convalescent plasma for severe COVID-19 based on evidence in other severe respiratory viral infections: a systematic review and meta-analysis. CMAJ 2020 Jul 06;192(27):E745-E755 [FREE Full text] [doi: 10.1503/cmaj.200642] [Medline: 32444482]

207. Piechotta V, Chai K, Valk S, Doree C, Monsef I, Wood E, et al. Convalescent plasma or hyperimmune immunoglobulin for people with COVID-19: a living systematic review. Cochrane Database Syst Rev 2020 Jul 10;7:CD013600. [doi: 10.1002/14651858.CD013600.pub2] [Medline: 32648959]

208. Sarkar S, Soni KD, Khanna P. Convalescent plasma is a clutch at straws in COVID-19 management! A systematic review and meta-analysis. J Med Virol 2021 Feb;93(2):1111-1118 [FREE Full text] [doi: 10.1002/jmv.26408] [Medline: 32776573 ]

209. Sun M, Xu Y, He H, Zhang L, Wang X, Qiu Q, et al. A potentially effective treatment for COVID-19: a systematic review and meta-analysis of convalescent plasma therapy in treating severe infectious disease. Int J Infect Dis 2020 Sep;98:334-346 [FREE Full text] [doi: 10.1016/j.ijid.2020.06.107] [Medline: 32634589]

210. Abdollahi H, Shiri I, Bevelacqua JJ, Jafarzadeh A, Rahmim A, Zaidi H, et al. Low dose radiation therapy and convalescent plasma: how a hybrid method may maximize benefits for COVID-19 patients. J Biomed Phys Eng 2020 Aug;10(4):387-394 [FREE Full text] [doi: 10.31661/jbpe.v0i0.2006-1125] [Medline: 32802787]

211. Annamaria P, Eugenia Q, Paolo S. Anti-SARS-CoV-2 hyperimmune plasma workflow. Transfus Apher Sci 2020 Oct;59(5):102850 [FREE Full text] [doi: 10.1016/j.transci.2020.102850] [Medline: $\underline{32540345]}$

212. Anudeep T, Jeyaraman M, Shetty D, Raj H, Ajay S, Rajeswari S, et al. Convalescent plasma as a plausible therapeutic option for nCOVID-19 - a review. J Clin Trials 2020;10(3):1-7.

213. Venkat Kumar G, Jeyanthi V, Ramakrishnan S. A short review on antibody therapy for COVID-19. New Microbes New Infect 2020 May;35:100682 [FREE Full text] [doi: 10.1016/j.nmni.2020.100682] [Medline: $\underline{\text { 32313660] }}$

214. Gasparyan AY, Misra DP, Yessirkepov M, Zimba O. Perspectives of immune therapy in coronavirus disease 2019. J Korean Med Sci 2020 May 11;35(18):e176 [FREE Full text] [doi: 10.3346/jkms.2020.35.e176] [Medline: $\underline{32383371]}$

215. Iftikhar A, Jabeen F, Manzoor M, Younis T, Shaheen M. Passive immunization: paradoxical and traditional method for new pandemic challenge COVID-19. Acta Microbiol Immunol Hung 2020 Jul 03;67(2):87-90. [doi: 10.1556/030.2020.01199] [Medline: 32619190]

216. Li S, Zhao H, Sun Y, Wang P, Li H, Duan M. [Application of convalescent plasma for the treatment of adult patients with coronavirus disease 2019]. Zhonghua Wei Zhong Bing Ji Jiu Yi Xue 2020 Jun;32(6):646-651. [doi: 10.3760/cma.j.cn121430-20200601-00479] [Medline: 32684206]

217. Lindholm PF, Ramsey G, Kwaan HC. Passive immunity for coronavirus disease 2019:a commentary on therapeutic aspects including convalescent plasma. Semin Thromb Hemost 2020 Oct;46(7):796-803 [FREE Full text] [doi:

10.1055/s-0040-1712157] [Medline: 32526774] 
218. Murphy M, Estcourt L, Grant-Casey J, Dzik S. International survey of trials of convalescent plasma to treat COVID-19 infection. Transfus Med Rev 2020 Jul;34(3):151-157 [FREE Full text] [doi: 10.1016/j.tmrv.2020.06.003] [Medline: 32703664]

219. Sayinalp B, Çinar OE, Haznedaroğlu İ. Perspectives for immune plasma treatment of COVID-19. Turk J Med Sci 2021 Feb 26;51(1):1-9. [doi: 10.3906/sag-2005-410] [Medline: $\underline{\text { 32718128] }}$

220. Subbarao K, Mordant F, Rudraraju R. Convalescent plasma treatment for COVID-19: tempering expectations with the influenza experience. Eur J Immunol 2020 Oct;50(10):1447-1453. [doi: 10.1002/eji.202048723] [Medline: 32886952]

221. Pawar AY, Hiray AP, Sonawane DD, Bhambar RS, Derle DV, Ahire YS. Convalescent plasma: a possible treatment protocol for COVID- 19 patients suffering from diabetes or underlying liver diseases. Diabetes Metab Syndr 2020;14(4):665-669 [FREE Full text] [doi: 10.1016/j.dsx.2020.05.023] [Medline: $\underline{32438330]}$

222. Bakhtawar N, Usman M, Khan M. Convalescent plasma therapy and its effects on COVID-19 patient outcomes: a systematic review of current literature. Cureus 2020 Aug 03;12(8):e9535 [FREE Full text] [doi: 10.7759/cureus.9535] [Medline: 32905148]

223. Chen B, Xia R. Early experience with convalescent plasma as immunotherapy for COVID-19 in China: knowns and unknowns. Vox Sang 2020 Aug;115(6):507-514 [FREE Full text] [doi: 10.1111/vox.12968] [Medline: 32516839]

224. Rajendran K, Krishnasamy N, Rangarajan J, Rathinam J, Natarajan M, Ramachandran A. Convalescent plasma transfusion for the treatment of COVID-19: systematic review. J Med Virol 2020 Sep;92(9):1475-1483 [FREE Full text] [doi: 10.1002/jmv.25961] [Medline: $\underline{32356910}$ ]

225. Valk S, Piechotta V, Chai K, Doree C, Monsef I, Wood E, et al. Convalescent plasma or hyperimmune immunoglobulin for people with COVID-19: a rapid review. Cochrane Database Syst Rev 2020 May 14;5:CD013600. [doi: 10.1002/14651858.CD013600] [Medline: 32406927]

226. Focosi D, Farrugia A. The art of the possible in approaching efficacy trials for COVID19 convalescent plasma. Int J Infect Dis 2021 Jan;102:244-246 [FRE Full text] [doi: 10.1016/j.ijid.2020.10.074] [Medline: $\underline{33130197]}$

227. Nagoba B, Gavkare A, Jamadar N, Mumbre S, Selkar S. Positive aspects, negative aspects and limitations of plasma therapy with special reference to COVID-19. J Infect Public Health 2020 Dec;13(12):1818-1822 [FREE Full text] [doi: 10.1016/j.jiph.2020.08.011] [Medline: $\underline{32900666]}$

228. Psaltopoulou T, Sergentanis TN, Pappa V, Politou M, Terpos E, Tsiodras S, et al. The emerging role of convalescent plasma in the treatment of COVID-19. Hemasphere 2020 Jun;4(3):e409 [FREE Full text] [doi: 10.1097/HS9.0000000000000409] [Medline: $\underline{\text { 32647807] }}$

229. Khulood D, Adil MS, Sultana R, Nimra. Convalescent plasma appears efficacious and safe in COVID-19. Ther Adv Infect Dis 2020;7:2049936120957931 [FREE Full text] [doi: 10.1177/2049936120957931] [Medline: 33062267]

230. Chua Vi Long K, Sayed A, Karki P, Acharya Y. Convalescent blood products in COVID-19: a narrative review. Ther Adv Infect Dis 2020;7:2049936120960646 [FREE Full text] [doi: 10.1177/2049936120960646] [Medline: $\underline{33014364]}$

231. Ouyang J, Isnard S, Lin J, Fombuena B, Peng X, Routy J, et al. Convalescent plasma: the relay baton in the race for coronavirus disease 2019 treatment. Front Immunol 2020;11:570063. [doi: 10.3389/fimmu.2020.570063] [Medline: $\underline{33072111]}$

232. Piyush R, Rajarshi K, Khan R, Ray S. Convalescent plasma therapy: a promising coronavirus disease 2019 treatment strategy. Open Biol 2020 Sep;10(9):200174 [FREE Full text] [doi: 10.1098/rsob.200174] [Medline: 32898468]

233. Rojas M, Rodríguez Y, Monsalve DM, Acosta-Ampudia Y, Camacho B, Gallo JE, et al. Convalescent plasma in Covid-19: possible mechanisms of action. Autoimmun Rev 2020 Jul;19(7):102554 [FREE Full text] [doi: 10.1016/j.autrev.2020.102554] [Medline: $\underline{\text { 32380316] }}$

234. Selvi V. Convalescent plasma: a challenging tool to treat COVID-19 patients-a lesson from the past and new perspectives. Biomed Res Int 2020;2020:2606058. [doi: 10.1155/2020/2606058] [Medline: 33029499]

235. Sharun K, Tiwari R, Iqbal Yatoo M, Patel SK, Natesan S, Dhama J, et al. Antibody-based immunotherapeutics and use of convalescent plasma to counter COVID-19: advances and prospects. Expert Opin Biol Ther 2020 Sep;20(9):1033-1046. [doi: 10.1080/14712598.2020.1796963] [Medline: 32744917$]$

236. Sullivan HC, Roback JD. Convalescent plasma: therapeutic hope or hopeless strategy in the SARS-CoV-2 pandemic. Transfus Med Rev 2020 Jul;34(3):145-150 [FREE Full text] [doi: 10.1016/j.tmrv.2020.04.001] [Medline: $\underline{32359788}$ ]

237. Yiğenoğlu TN, Hacıbekiroğlu T, Berber, Dal MS, Baştürk A, Namdaroğlu S, et al. Convalescent plasma therapy in patients with COVID-19. J Clin Apher 2020 Aug;35(4):367-373 [FREE Full text] [doi: 10.1002/jca.21806] [Medline: $\underline{32643200]}$

238. Accorsi P, Berti P, de Angelis V, De Silvestro G, Mascaretti L, Ostuni A, Italian Society for Transfusion Medicine Immunohaematology (SIMTI) Italian Society for Hemapheresis cell Manipulation (SIdEM). Position paper on the preparation of immune plasma to be used in the treatment of patients with COVID-19. Transfus Apher Sci 2020 Aug;59(4):102817 [FREE Full text] [doi: 10.1016/j.transci.2020.102817] [Medline: 32532691]

239. Albalawi M, Zaidi SZA, AlShehry N, AlAskar A, Zaidi ARZ, Abdallah RNM, et al. Safety and efficacy of convalescent plasma to treat severe COVID-19: protocol for the Saudi collaborative multicenter phase II study. JMIR Res Protoc 2020 Oct 02;9(10):e23543 [FREE Full text] [doi: 10.2196/23543] [Medline: 32903199] 
240. Al-Riyami AZ, Schäfer R, van den Berg K, Bloch EM, Estcourt LJ, Goel R, et al. Clinical use of convalescent plasma in the COVID-19 pandemic: a transfusion-focussed gap analysis with recommendations for future research priorities. Vox Sang 2021 Jan;116(1):88-98 [FREE Full text] [doi: 10.1111/vox.12973] [Medline: $\underline{\text { 32542847] }}$

241. Albahri O, Al-Obaidi JR, Zaidan A, Albahri A, Zaidan B, Salih MM, et al. Helping doctors hasten COVID-19 treatment: towards a rescue framework for the transfusion of best convalescent plasma to the most critical patients based on biological requirements via $\mathrm{ml}$ and novel MCDM methods. Comput Methods Programs Biomed 2020 Nov;196:105617 [FREE Full text] [doi: 10.1016/j.cmpb.2020.105617] [Medline: 32593060]

242. Bloch EM, Goel R, Wendel S, Burnouf T, Al-Riyami AZ, Ang AL, et al. Guidance for the procurement of COVID-19 convalescent plasma: differences between high- and low-middle-income countries. Vox Sang 2021 Jan;116(1):18-35 [FREE Full text] [doi: 10.1111/vox.12970] [Medline: 32533868 ]

243. Blackall D, Wulff S, Roettger T, Jacobs L, Lacasse A, Patri M, et al. Rapid establishment of a COVID-19 convalescent plasma program in a regional health care delivery network. Transfusion 2020 Oct;60(10):2203-2209 [FREE Full text] [doi: 10.1111/trf.16026] [Medline: 32748963]

244. Budhai A, Wu AA, Hall L, Strauss D, Paradiso S, Alberigo J, et al. How did we rapidly implement a convalescent plasma

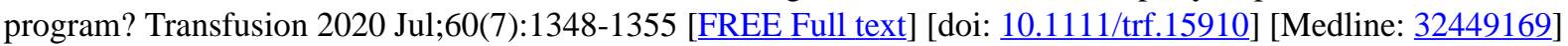

245. Chowdhury FR, Hoque A, Chowdhury FUH, Amin MR, Rahim A, Rahman MM, et al. Convalescent plasma transfusion therapy in severe COVID-19 patients- a safety, efficacy and dose response study: a structured summary of a study protocol of a phase II randomized controlled trial. Trials 2020 Oct 26;21(1):883 [FREE Full text] [doi: 10.1186/s13063-020-04734-z] [Medline: 33106167]

246. Eckhardt CM, Cummings MJ, Rajagopalan KN, Borden S, Bitan ZC, Wolf A, et al. Evaluating the efficacy and safety of human anti-SARS-CoV-2 convalescent plasma in severely ill adults with COVID-19: a structured summary of a study protocol for a randomized controlled trial. Trials 2020 Jun 08;21(1):499 [FREE Full text] [doi: 10.1186/s13063-020-04422-y] [Medline: $\underline{32513308]}$

247. Janssen M, Schäkel U, Djuka Fokou C, Krisam J, Stermann J, Kriegsmann K, et al. A randomized open label phase-II clinical trial with or without infusion of plasma from subjects after convalescence of SARS-CoV-2 infection in high-risk patients with confirmed severe SARS-CoV-2 disease (RECOVER): a structured summary of a study protocol for a randomised controlled trial. Trials 2020 Oct 06;21(1):828 [FREE Full text] [doi: 10.1186/s13063-020-04735-y] [Medline: $\underline{33023671]}$

248. Epstein J, Burnouf T. Points to consider in the preparation and transfusion of COVID-19 convalescent plasma. Vox Sang 2020 Aug;115(6):485-487 [FREE Full text] [doi: 10.1111/vox.12939] [Medline: 32319102]

249. Epstein J, Smid WM, Wendel S, Somuah D, Burnouf T. Use of COVID-19 convalescent plasma in low- and middle-income countries: a call for ethical principles and the assurance of quality and safety. Vox Sang 2021 Jan;116(1):13-14 [FREE Full text] [doi: 10.1111/vox.12964] [Medline: 32464700 ]

250. Hassan MO, Osman AA, Elbasit HEA, Hassan HE, Rufai H, Satti MM, et al. Convalescent plasma as a treatment modality for coronavirus disease 2019 in Sudan. Transfus Apher Sci 2020 Dec;59(6):102918 [FREE Full text] [doi: 10.1016/j.transci.2020.102918] [Medline: 32900597]

251. Ipe TS, Le T, Quinn B, Kellar S, Clark M, Carlisle S, et al. Provision of COVID-19 convalescent plasma in a resource-constrained state. Transfusion 2020 Dec;60(12):2828-2833 [FREE Full text] [doi: 10.1111/trf.16118] [Medline: $\underline{32989778]}$

252. Li L, Yang R, Wang J, Lv Q, Ren M, Zhao L, et al. Feasibility of a pilot program for COVID-19 convalescent plasma collection in Wuhan, China. Transfusion 2020 Aug;60(8):1773-1777 [FREE Full text] [doi: 10.1111/trf.15921] [Medline: 32491199]

253. Pei S, Yuan X, Zhang Z, Yao R, Xie Y, Shen M, et al. Convalescent plasma to treat COVID-19: Chinese strategy and experiences. medRxiv. Preprint posted online on April 11, 2020. [doi: 10.1101/2020.04.07.20056440]

254. Perotti C, Del Fante C, Baldanti F, Franchini M, Percivalle E, Vecchio Nepita E, et al. Plasma from donors recovered from the new coronavirus 2019 as therapy for critical patients with COVID-19 (COVID-19 plasma study): a multicentre study protocol. Intern Emerg Med 2020 Aug;15(5):819-824. [doi: 10.1007/s11739-020-02384-2] [Medline: 32468508]

255. Seghatchian J, Lanza F. Convalescent plasma, an apheresis research project targeting and motivating the fully recovered COVID 19 patients: a rousing message of clinical benefit to both donors and recipients alike. Transfus Apher Sci 2020 Jun;59(3):102794 [FREE Full text] [doi: 10.1016/j.transci.2020.102794] [Medline: 32448638]

256. Yılmaz S, Ertuğrul Örüç N, Özcebe O, Azap A, Çetin AT, Yenicesu İ, et al. Regulatory consideration on preparation and clinical use of COVID-19 convalescent plasma. Transfus Apher Sci 2020 Oct;59(5):102846 [FREE Full text] [doi: 10.1016/j.transci.2020.102846] [Medline: 32593519]

257. Amanat F, Stadlbauer D, Strohmeier S, Nguyen THO, Chromikova V, McMahon M, et al. A serological assay to detect SARS-CoV-2 seroconversion in humans. Nat Med 2020 Jul;26(7):1033-1036. [doi: 10.1038/s41591-020-0913-5] [Medline: 32398876]

258. Byrnes J, Zhou X, Lui I, Elledge S, Glasgow J, Lim S, et al. A SARS-CoV-2 serological assay to determine the presence of blocking antibodies that compete for human ACE2 binding. medRxiv. Preprint posted online on May 29, 2020. [doi: 10.1101/2020.05.27.20114652] [Medline: 32511506] 
259. Gattinger P, Borochova K, Dorofeeva Y, Henning R, Kiss R, Kratzer B, et al. Antibodies in serum of convalescent patients following mild COVID-19 do not always prevent virus-receptor binding. Allergy 2021 Mar;76(3):878-883. [doi: 10.1111/all.14523] [Medline: 32734595$]$

260. DomBourian MG, Annen K, Huey L, Andersen G, Merkel PA, Jung S, et al. Analysis of COVID-19 convalescent plasma for SARS-CoV-2 IgG using two commercial immunoassays. J Immunol Methods 2020 Nov;486:112837 [FREE Full text] [doi: 10.1016/j.jim.2020.112837] [Medline: 32828791]

261. Ding S, Laumaea A, Gasser R, Medjahed H, Pancera M, Stamatatos L, et al. Antibody binding to SARS-CoV-2 S glycoprotein correlates with, but does not predict neutralization. bioRxiv. Preprint posted online on September 08, 2020. [doi: 10.1101/2020.09.08.287482] [Medline: 32935094]

262. Ianevski A, Yao R, Fenstad M, Biza S, Zusinaite E, Reisberg T, et al. Potential antiviral options against SARS-CoV-2 infection. Viruses 2020 Jun 13;12(6):642 [FREE Full text] [doi: 10.3390/v12060642] [Medline: 32545799]

263. Schmidt F, Weisblum Y, Muecksch F, Hoffmann H, Michailidis E, Lorenzi J, et al. Measuring SARS-CoV-2 neutralizing antibody activity using pseudotyped and chimeric viruses. J Exp Med 2020 Nov 02;217(11):e20201181 [FREE Full text] [doi: 10.1084/jem.20201181] [Medline: $\underline{\text { 32692348] }}$

264. Wang X, Guo X, Xin Q, Pan Y, Hu Y, Li J, et al. Neutralizing antibody responses to severe acute respiratory syndrome coronavirus 2 in coronavirus disease 2019 inpatients and convalescent patients. Clin Infect Dis 2020 Dec 17;71(10):2688-2694 [FREE Full text] [doi: 10.1093/cid/ciaa721] [Medline: 32497196$]$

265. Muruato A, Fontes-Garfias C, Ren P, Garcia-Blanco M, Menachery V, Xie X, et al. A high-throughput neutralizing antibody assay for COVID-19 diagnosis and vaccine evaluation. Nat Commun 2020 Aug 13;11(1):4059. [doi: 10.1038/s41467-020-17892-0] [Medline: $\underline{\text { 32792628] }}$

266. Ragnesola B, Jin D, Lamb CC, Shaz BH, Hillyer CD, Luchsinger LL. COVID19 antibody detection using lateral flow assay tests in a cohort of convalescent plasma donors. BMC Res Notes 2020 Aug 06;13(1):372 [FREE Full text] [doi: 10.1186/s13104-020-05212-0] [Medline: 32762746]

267. Yang HS, Racine-Brzostek SE, Lee WT, Hunt D, Yee J, Chen Z, et al. SARS-CoV-2 antibody characterization in emergency department, hospitalized and convalescent patients by two semi-quantitative immunoassays. Clin Chim Acta 2020 Oct;509:117-125 [FREE Full text] [doi: 10.1016/j.cca.2020.06.004] [Medline: $\underline{\text { 2505774] }}$

268. de Assis RR, Jain A, Nakajima R, Jasinskas A, Felgner J, Obiero J, Prometheus Study Group, et al. Analysis of SARS-CoV-2 antibodies in COVID-19 convalescent plasma using a coronavirus antigen microarray. bioRxiv. Preprint posted online on May 8, 2020. [doi: 10.1101/2020.04.15.043364] [Medline: $\underline{32511302]}$

269. Dulipsingh L, Ibrahim D, Schaefer EJ, Crowell R, Diffenderfer MR, Williams K, et al. SARS-CoV-2 serology and virology trends in donors and recipients of convalescent plasma. Transfus Apher Sci 2020 Dec;59(6):102922. [doi: 10.1016/j.transci.2020.102922] [Medline: $\underline{\text { 32883593] }}$

270. Ikegami S, Benirschke R, Flanagan T, Tanna N, Klein T, Elue R, et al. Persistence of SARS-CoV-2 nasopharyngeal swab PCR positivity in COVID-19 convalescent plasma donors. Transfusion 2020 Dec;60(12):2962-2968 [FREE Full text] [doi: 10.1111/trf.16015] [Medline: $\underline{\text { 32840002] }}$

271. Ma H, Zhao D, Zeng W, Yang Y, Hu X, Zhou P, et al. Decline of SARS-CoV-2-specific IgG, IgM and IgA in convalescent COVID-19 patients within 100 days after hospital discharge. Sci China Life Sci 2020 Aug 28:1-4 [FREE Full text] [doi: 10.1007/s11427-020-1805-0] [Medline: 32876887]

272. Danh K, Karp D, Robinson P, Seftel D, Stone M, Simmons G, et al. Detection of SARS-CoV-2 neutralizing antibodies with a cell-free PCR assay. medRxiv. Preprint posted online on June 2, 2020. [doi: 10.1101/2020.05.28.20105692] [Medline: $\underline{32577696]}$

273. Hartman WR, Hess AS, Connor JP. Persistent viral RNA shedding after COVID-19 symptom resolution in older convalescent plasma donors. Transfusion 2020 Oct;60(10):2189-2191 [FREE Full text] [doi: 10.1111/trf.15927] [Medline: 32533556]

274. Abe K, Li Z, Samson R, Samavarchi-Tehrani P, Valcourt E, Wood H, et al. A simple protein-based surrogate neutralization assay for SARS-CoV-2. JCI Insight 2020 Oct 02;5(19):e142362. [doi: 10.1172/jci.insight.142362] [Medline: 32870820]

275. Beaudoin-Bussières G, Laumaea A, Anand SP, Prévost J, Gasser R, Goyette G, et al. Decline of humoral responses against SARS-CoV-2 spike in convalescent individuals. mBio 2020 Oct 16;11(5):e02590-e02520 [FREE Full text] [doi: 10.1128/mBio.02590-20] [Medline: 33067385]

276. Benner S, Patel E, Laeyendecker O, Pekosz A, Littlefield K, Eby Y, et al. SARS-CoV-2 antibody avidity responses in COVID-19 patients and convalescent plasma donors. J Infect Dis 2020 Nov 13;222(12):1974-1984 [FREE Full text] [doi: 10.1093/infdis/jiaa581] [Medline: 32910175]

277. Boonyaratanakornkit J, Morishima C, Selke S, Zamora D, McGuffin S, Shapiro A, et al. Clinical, laboratory, and temporal predictors of neutralizing antibodies to SARS-CoV-2 after COVID-19. medRxiv. Preprint posted online on October 21, 2020. [doi: 10.1101/2020.10.06.20207472] [Medline: $\underline{33052361]}$

278. Gniadek TJ, Thiede JM, Matchett WE, Gress AR, Pape KA, Fiege JK, et al. SARS-CoV-2 neutralization and serology testing of COVID-19 convalescent plasma from donors with nonsevere disease. Transfusion 2021 Jan;61(1):17-23. [doi:

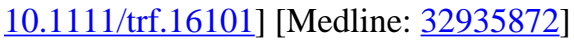


279. Patel EU, Bloch EM, Clarke W, Hsieh Y, Boon D, Eby Y, et al. Comparative performance of five commercially available serologic assays to detect antibodies to SARS-CoV-2 and identify individuals with high neutralizing titers. medRxiv. September 2, 2020 2021. [doi: 10.1101/2020.08.31.20184788]

280. Harvala H, Mehew J, Robb M, Ijaz S, Dicks S, Patel M, NHS Blood and Transplant Convalescent Plasma Testing Group. Convalescent plasma treatment for SARS-CoV-2 infection: analysis of the first 436 donors in England, 22 April to 12 May 2020. Euro Surveill 2020 Jul;25(28):2001260 [FREE Full text] [doi: 10.2807/1560-7917.ES.2020.25.28.2001260] [Medline: 32700670]

281. Wendel S, Kutner JM, Machado R, Fontão-Wendel R, Bub C, Fachini R, et al. Screening for SARS-CoV-2 antibodies in convalescent plasma in Brazil: preliminary lessons from a voluntary convalescent donor program. Transfusion 2020 Dec;60(12):2938-2951 [FREE Full text] [doi: 10.1111/trf.16065] [Medline: 32935877]

282. Zeng C, Evans J, Pearson R, Qu P, Zheng Y, Robinson R, et al. Neutralizing antibody against SARS-CoV-2 spike in COVID-19 patients, health care workers and convalescent plasma donors: a cohort study using a rapid and sensitive high-throughput neutralization assay. medRxiv. Preprint posted online on August 4, 2020. [doi: 10.1101/2020.08.02.20166819] [Medline: 32793931]

283. Dogan M, Kozhaya L, Placek L, Gunter C, Yigit M, Hardy R, et al. Novel SARS-CoV-2 specific antibody and neutralization assays reveal wide range of humoral immune response during COVID-19. medRxiv. Preprint posted online on October 14, 2020. [doi: 10.1101/2020.07.07.20148106] [Medline: $\underline{32676617}$ ]

284. Jungbauer C, Weseslindtner L, Weidner L, Gänsdorfer S, Farcet MR, Gschaider-Reichhart E, et al. Characterization of 100 sequential SARS-CoV-2 convalescent plasma donations. Transfusion 2021 Jan;61(1):12-16 [FREE Full text] [doi: 10.1111/trf.16119] [Medline: 32978802]

285. Li L, Tong X, Chen H, He R, Lv Q, Yang R, et al. Characteristics and serological patterns of COVID-19 convalescent plasma donors: optimal donors and timing of donation. Transfusion 2020 Aug;60(8):1765-1772 [FREE Full text] [doi:

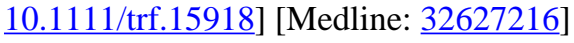

286. Ni L, Ye F, Cheng ML, Feng Y, Deng YQ, Zhao H, et al. Detection of SARS-CoV-2-specific humoral and cellular immunity in COVID-19 convalescent individuals. Immunity 2020 Jun 16;52(6):971-977.e3 [FREE Full text] [doi: 10.1016/j.immuni.2020.04.023] [Medline: $\underline{\text { 32413330] }}$

287. Robbiani D, Gaebler C, Muecksch F, Lorenzi J, Wang Z, Cho A, et al. Convergent antibody responses to SARS-CoV-2 infection in convalescent individuals. bioRxiv. Preprint posted online on May 22, 2020. [doi: 10.1101/2020.05.13.092619] [Medline: 32511384]

288. Salazar E, Kuchipudi S, Christensen P, Eagar T, Yi X, Zhao P, et al. Relationship between anti-spike protein antibody titers and SARS-CoV-2 virus neutralization in convalescent plasma. bioRxiv. Preprint posted online on June 9, 2020. [doi: 10.1101/2020.06.08.138990] [Medline: $\underline{\text { 32577662] }}$

289. Weidner L, Gänsdorfer S, Unterweger S, Weseslindtner L, Drexler C, Farcet M, et al. Quantification of SARS-CoV-2 antibodies with eight commercially available immunoassays. J Clin Virol 2020 Aug;129:104540 [FREE Full text] [doi: 10.1016/i.jcv.2020.104540] [Medline: 32652475]

290. Natarajan H, Crowley A, Butler S, Xu S, Weiner J, Bloch E, et al. SARS-CoV-2 antibody signatures robustly predict diverse antiviral functions relevant for convalescent plasma therapy. medRxiv. Preprint posted online on September 18, 2020. [doi: 10.1101/2020.09.16.20196154] [Medline: $\underline{32995801]}$

291. Stadlbauer D, Baine I, Amanat F, Jiang K, Lally K, Krammer F, et al. Anti-SARS-CoV-2 spike antibodies are stable in convalescent plasma when stored at $4^{\circ}$ Celsius for at least 6 weeks. Transfusion 2020 Oct;60(10):2457-2459 [FREE Full text] [doi: $10.1111 /$ trf.16047] [Medline: 32798271$]$

292. Jahrsdörfer B, Kroschel J, Ludwig C, Corman V, Schwarz T, Körper S, et al. Independent side-by-side validation and comparison of 4 serological platforms for SARS-CoV-2 antibody testing. J Infect Dis 2021 Mar 03;223(5):796-801 [FREE Full text] [doi: 10.1093/infdis/jiaa656] [Medline: $\underline{\text { 33064789] }}$

293. Johnson M, Wagstaffe H, Gilmour K, Mai A, Lewis J, Hunt A, et al. Evaluation of a novel multiplexed assay for determining IgG levels and functional activity to SARS-CoV-2. J Clin Virol 2020 Sep;130:104572 [FREE Full text] [doi:

10.1016/j.jcv.2020.104572] [Medline: 32769024]

294. di Mauro G, Scavone C, Rafaniello C, Rossi F, Capuano A. SARS-Cov-2 infection: response of human immune system and possible implications for the rapid test and treatment. Int Immunopharmacol 2020 Jul;84:106519 [FREE Full text] [doi: 10.1016/j.intimp.2020.106519] [Medline: 32311668]

295. Recommendations for investigational COVID-19 convalescent plasma. US Food and Drug Administration. URL: https:/ /www.fda.gov/vaccines-blood-biologics/investigational-new-drug-ind-or-device-exemption-ide-process-cber/ recommendations-investigational-covid-19-convalescent-plasma [accessed 2020-06-01]

296. FDA in brief: FDA updates emergency use authorization for COVID-19 convalescent plasma to reflect new data. US Food and Drug Administration. URL: http://www.fda.gov/news-events/fda-brief/

fda-brief-fda-updates-emergency-use-authorization-covid-19-convalescent-plasma-reflect-new-data [accessed 2021-02-16]

297. Klein S, Pekosz A, Park H, Ursin R, Shapiro J, Benner S, et al. Sex, age, and hospitalization drive antibody responses in a COVID-19 convalescent plasma donor population. J Clin Invest 2020 Nov 02;130(11):6141-6150. [doi: 10.1172/JCI142004] [Medline: $\underline{\text { 32764200] }}$ 
298. Asrani P, Hassan MI. SARS-CoV-2 mediated lung inflammatory responses in host: targeting the cytokine storm for therapeutic interventions. Mol Cell Biochem 2021 Feb;476(2):675-687 [FREE Full text] [doi: 10.1007/s11010-020-03935-z] [Medline: 33064288 ]

299. Kato H, Uruma M, Okuyama Y, Fujita H, Handa M, Tomiyama Y, et al. Incidence of transfusion-related adverse reactions per patient reflects the potential risk of transfusion therapy in Japan. Am J Clin Pathol 2013 Aug;140(2):219-224. [doi: 10.1309/AJCP6SBPOX0UWHEK] [Medline: 23897258]

300. Chang L, Yan Y, Wang L. Coronavirus disease 2019: coronaviruses and blood safety. Transfus Med Rev 2020 Apr;34(2):75-80 [FREE Full text] [doi: 10.1016/j.tmrv.2020.02.003] [Medline: 32107119]

301. Keil SD, Ragan I, Yonemura S, Hartson L, Dart NK, Bowen R. Inactivation of severe acute respiratory syndrome coronavirus 2 in plasma and platelet products using a riboflavin and ultraviolet light-based photochemical treatment. Vox Sang 2020 Aug;115(6):495-501 [FREE Full text] [doi: 10.1111/vox.12937] [Medline: $\underline{32311760]}$

302. Abraham J. Passive antibody therapy in COVID-19. Nat Rev Immunol 2020 Jul;20(7):401-403 [FREE Full text] [doi: 10.1038/s41577-020-0365-7] [Medline: 32533109]

303. Halstead SB, Akkina R. COVID-19 and SARS Coronavirus 2: antibodies for the immediate rescue and recovery phase. Front Immunol 2020;11:1196. [doi: 10.3389/fimmu.2020.01196] [Medline: 32574267]

304. Luchsinger LL, Ransegnola BP, Jin DK, Muecksch F, Weisblum Y, Bao W, et al. Serological assays estimate highly variable SARS-CoV-2 neutralizing antibody activity in recovered COVID-19 patients. J Clin Microbiol 2020 Nov 18;58(12):e02005-e02020 [FREE Full text] [doi: 10.1128/JCM.02005-20] [Medline: 32917729]

305. Ibarrondo FJ, Fulcher JA, Goodman-Meza D, Elliott J, Hofmann C, Hausner MA, et al. Rapid decay of anti-SARS-CoV-2 antibodies in persons with mild Covid-19. N Engl J Med 2020 Sep 10;383(11):1085-1087 [FREE Full text] [doi: 10.1056/NEJMc2025179] [Medline: 32706954]

306. Gudbjartsson DF, Norddahl GL, Melsted P, Gunnarsdottir K, Holm H, Eythorsson E, et al. Humoral immune response to SARS-CoV-2 in Iceland. N Engl J Med 2020 Oct 29;383(18):1724-1734 [FREE Full text] [doi: 10.1056/NEJMoa2026116] [Medline: $\underline{\text { 32871063] }}$

307. Salazar G, Zhang N, Fu T, An Z. Antibody therapies for the prevention and treatment of viral infections. NPJ Vaccines 2017;2:19. [doi: 10.1038/s41541-017-0019-3] [Medline: 29263875]

308. Chatterjee SK, Saha S, Munoz MNM. Molecular pathogenesis, immunopathogenesis and novel therapeutic strategy against COVID-19. Front Mol Biosci 2020;7:196. [doi: 10.3389/fmolb.2020.00196] [Medline: 32850977]

309. Ou X, Liu Y, Lei X, Li P, Mi D, Ren L, et al. Characterization of spike glycoprotein of SARS-CoV-2 on virus entry and its immune cross-reactivity with SARS-CoV. Nat Commun 2020 Mar 27;11(1):1620. [doi: 10.1038/s41467-020-15562-9] [Medline: 32221306]

310. Peng Y, Mentzer AJ, Liu G, Yao X, Yin Z, Dong D, Oxford Immunology Network Covid-19 Response T cell Consortium, ISARIC4C Investigators, et al. Broad and strong memory CD4 and CD8 T cells induced by SARS-CoV-2 in UK convalescent individuals following COVID-19. Nat Immunol 2020 Nov;21(11):1336-1345. [doi: 10.1038/s41590-020-0782-6] [Medline: 32887977]

311. Toor SM, Saleh R, Sasidharan Nair V, Taha RZ, Elkord E. T-cell responses and therapies against SARS-CoV-2 infection. Immunology 2021 Jan;162(1):30-43 [FREE Full text] [doi: 10.1111/imm.13262] [Medline: 32935333]

312. Li R, Ma X, Deng J, Chen Q, Liu W, Peng Z, et al. Differential efficiencies to neutralize the novel mutants B.1.1.7 and 501Y.V2 by collected sera from convalescent COVID-19 patients and RBD nanoparticle-vaccinated rhesus macaques. Cell Mol Immunol 2021 Feb 12:1 [FREE Full text] [doi: 10.1038/s41423-021-00641-8] [Medline: 33580167]

313. Diamond M, Chen R, Xie X, Case J, Zhang X, VanBlargan L, et al. SARS-CoV-2 variants show resistance to neutralization by many monoclonal and serum-derived polyclonal antibodies. Res Square. Preprint posted online on February 10, 2021. [doi: 10.21203/rs.3.rs-228079/v1] [Medline: 33594356]

314. Seehra J, Pandis N, Koletsi D, Fleming P. Use of quality assessment tools in systematic reviews was varied and inconsistent. J Clin Epidemiol 2016 Jan;69:179-84.e5. [doi: 10.1016/j.jclinepi.2015.06.023] [Medline: 26151664]

315. Armijo-Olivo S, Stiles CR, Hagen NA, Biondo PD, Cummings GG. Assessment of study quality for systematic reviews: a comparison of the Cochrane Collaboration Risk of Bias Tool and the Effective Public Health Practice Project Quality Assessment Tool: methodological research. J Eval Clin Pract 2012 Feb;18(1):12-18. [doi: 10.1111/j.1365-2753.2010.01516.x] [Medline: 20698919]

316. Raynaud M, Zhang H, Louis K, Goutaudier V, Wang J, Dubourg Q, et al. COVID-19-related medical research: a meta-research and critical appraisal. BMC Med Res Methodol 2021 Jan 04;21(1):1 [FREE Full text] [doi: 10.1186/s12874-020-01190-w] [Medline: 33397292]

317. Keith P, Day M, Choe C, Perkins L, Moyer L, Hays E, et al. The successful use of therapeutic plasma exchange for severe COVID-19 acute respiratory distress syndrome with multiple organ failure. SAGE Open Med Case Rep 2020;8:2050313X20933473 [FREE Full text] [doi: 10.1177/2050313X20933473] [Medline: 32595974]

318. Shander A, Goobie S, Warner M, Aapro M, Bisbe E, Perez-Calatayud A, International Foundation of Patient Blood Management (IFPBM) and Society for the Advancement of Blood Management (SABM) Work Group. Essential role of patient blood management in a pandemic: a call for action. Anesth Analg 2020 Jul;131(1):74-85 [FREE Full text] [doi: 10.1213/ANE.0000000000004844] [Medline: 32243296] 


\section{Abbreviations}

ACE-2: angiotensin-converting enzyme 2

CP: convalescent plasma

ELISA: enzyme-linked immunosorbent assay

EPHPP: Effective Public Health Practice Project

EUA: Emergency Use Authorization

FDA: Food and Drug Administration

Ig: immunoglobulin

MERS-CoV: Middle East respiratory syndrome-related coronavirus

OR: odds ratio

PCR: polymerase chain reaction

PRISMA: Preferred Reporting Items for Systematic Reviews and Meta-Analyses

RBD: receptor binding domain

RCT: randomized controlled trial

ROM: ratio of mean

SARS-CoV: severe acute respiratory syndrome-related coronavirus

TACO: transfusion-associated circulatory overload

TRALI: transfusion-related lung injury

Edited by T Sanchez; submitted 10.11.20; peer-reviewed by V Curin, $N$ Hardikar; comments to author 27.01.21; accepted 19.02.21; published 07.04.21

Please cite as:

Peng HT, Rhind SG, Beckett A

Convalescent Plasma for the Prevention and Treatment of COVID-19: A Systematic Review and Quantitative Analysis

JMIR Public Health Surveill 2021;7(4):e25500

URL: https://publichealth.jmir.org/2021/4/e25500

doi: $\underline{10.2196 / 25500}$

PMID: 33825689

CHenry T Peng, Shawn G Rhind, Andrew Beckett. Originally published in JMIR Public Health and Surveillance (http://publichealth.jmir.org), 07.04.2021. This is an open-access article distributed under the terms of the Creative Commons Attribution License (https://creativecommons.org/licenses/by/4.0/), which permits unrestricted use, distribution, and reproduction in any medium, provided the original work, first published in JMIR Public Health and Surveillance, is properly cited. The complete bibliographic information, a link to the original publication on http://publichealth.jmir.org, as well as this copyright and license information must be included. 